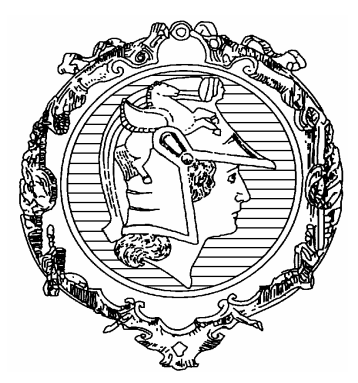

\title{
CRITÉRIOS DE AVALIAÇÃO DE SUSTENTABILIDADE AMBIENTAL DOS SISTEMAS PREDIAIS HIDRÁULICOS E SANITÁRIOS EM EDIFÍCIOS DE ESCRITÓRIOS
}

Dissertação apresentada à Escola Politécnica da Universidade de São Paulo para obtenção do título de Mestre em Engenharia

Área de Concentração: Engenharia de Construção Civil

Orientador:

Prof. Dr. Orestes Marraccini Gonçalves

São Paulo 


\section{FOLHA DE APROVAÇÃO}

Andreza Kalbusch

Critérios de Avaliação de Sustentabilidade Ambiental dos Sistemas Prediais Hidráulicos e Sanitários em Edifícios de Escritórios

Dissertação apresentada à Escola Politécnica da Universidade de São Paulo para obtenção do título de Mestre em Engenharia

Área de Concentração: Engenharia de Construção Civil

Aprovado em:

Banca Examinadora

Prof. Dr.

Instituição:

Assinatura:

Prof. Dr.

Instituição:

Assinatura:

Prof. Dr.

Instituição:

Assinatura: 
$\mathcal{A}$ mers pais, Hélolo e Nazillda e à

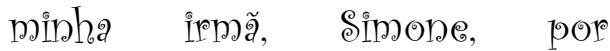
acreditarem, por apoiarem e

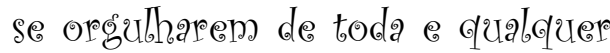
conduista, sempre. 


\section{AGRADECIMENTOS}

Ao Prof. Dr. Orestes Marraccini Gonçalves, por me apresentar ao tema, despertando o interesse para este estudo. Agradeço pela oportunidade de aprender, pelo conhecimento repassado no campo técnico e, principalmente, no campo humano. Agradeço pela compreensão e pela sensibilidade.

À Prof ${ }^{a}$. Dra. Marina Sangói de Oliveira Ilha e ao Prof. Dr. Racine Tadeu Prado, pela importante contribuição. À Fátima Domingues, por ser muito prestativa e competente.

À Prof ${ }^{a}$. Dra. Vanessa Gomes da Silva, por prontamente me receber e por ceder materiais aos quais não teria acesso para pesquisa. Ao Prof. Dr. Francisco Ferreira Cardoso, pela cortesia e pelo importante esclarecimento de algumas dúvidas durante o desenvolvimento do trabalho. Ao Prof. Dr. Marcos Jorge Santana, por me levar a pensar sobre aspectos da vida sobre os quais eu não pensava antes.

A Luciana, Augusto e Mônica, grandes amigos que conheci graças às aulas na PoliUSP e que me ensinaram valores que vão além das discussões técnicas. A Daniana e Michely, pelas sessões de desabafo, de sorrisos, de alegria.

Ao Tiago, por todos os momentos, felizes e tristes; pela compreensão e por tudo que está por vir. A Simone e Pedro, por me acolherem e por me darem ouvidos nas situações difíceis; pela animação e pela diversão em qualquer situação, sempre.

Aos meus pais, pelo exemplo de vida, de batalha; por não desistirem nunca; por terem se esforçado em tantos sentidos para que minha irmã e eu fôssemos felizes; por tudo que nos ensinaram.

A Chica e Fígaro, por estarem sempre a meu lado nos momentos mais difíceis, por terem me ajudado a superar tudo, por serem um antídoto contra qualquer tristeza e depressão. 


\title{
RESUMO
}

\begin{abstract}
KAlBUSCH, A. Critérios de Avaliação de Sustentabilidade Ambiental dos Sistemas Prediais Hidráulicos e Sanitários em Edifícios de Escritórios. 2006. 162 f. Dissertação (Mestrado) - Escola Politécnica, Universidade de São Paulo, São Paulo, 2006.
\end{abstract}

A definição de desenvolvimento sustentável da World Commission on Environment and Devolopment aponta para um desenvolvimento econômico e social capaz de atender às necessidades desta geração, não comprometendo o atendimento das necessidades das gerações futuras. A gestão do uso da água, enquanto estratégia para preservação deste recurso, vem ao encontro do conceito de desenvolvimento sustentável, uma vez que pretende garantir que haja água disponível para as gerações futuras e que, sem este recurso, não há possibilidade de vida no planeta. Em relação a edifícios, a conservação da água pode ser alcançada através do emprego de práticas e de tecnologias que levem a uma utilização mais sustentável deste recurso, sem que haja interferência no conforto dos usuários. O presente trabalho pretende ser uma contribuição e um incentivo às práticas de conservação da água no ambiente construído, além de ser uma contribuição para a aplicação dos conceitos de sustentabilidade ambiental no projeto e execução de sistemas prediais hidráulicos e sanitários na construção civil brasileira. Para isso, detalha-se a maneira como alguns sistemas de avaliação de sustentabilidade ambiental de edifícios de escritórios avaliam itens relacionados aos sistemas prediais hidráulicos e sanitários e ao uso da água. O objetivo é aprofundar os critérios de avaliação de sustentabilidade ambiental dos sistemas prediais hidráulicos e do uso da água propostos para edifícios de escritório com base na documentação técnica e normalização brasileira consultadas.

Palavras-chave: Sustentabilidade ambiental; Sistemas prediais hidráulicos e sanitários. 


\begin{abstract}
KALBUSCH, A. Assessment Criteria for Environmental Sustainability on Office Buildings Hydraulic and Sanitary Systems. 2006. 162 f. Dissertation (Master of Science) Escola Politécnica, Universidade de São Paulo, São Paulo, 2006.

The World Commission on Environment and Development definition for sustainable development points towards a social and economic development capable of taking care of the necessities of this generation without compromising the necessities of future generations. Water management creates strategies that secure the preservation of this resource and also fits the concept of sustainable development, since it intends to ensure the availability of water for generations to come and understands that without this resource there is no possibility of life on Earth. When it comes to buildings, water preservation is possible through the application of practices and technologies that will lead to a more sustainable use of this resource, without interfering on the daily activities of users and their needs and comfort. The purpose of this study is promoting actions regarding water preservation in buildings and contributing to the application of environmental sustainability concepts in hydraulic and sanitary systems on the Brazilian construction industry. For that reason it contains the details and the evaluation criteria on how some of the environmental assessment methods actually evaluate items that are related to hydraulic and sanitary systems and water usage. Therefore its main objective is to study the evaluation criteria for environmental sustainability on hydraulic and sanitary systems and water use for office buildings based on the consulted technical documentation and relevant Brazilian standards.
\end{abstract}

Keywords: Environmental Sustainability; Hydraulic and Sanitary Systems. 


\section{LISTA DE ILUSTRAÇÕES}

Figura 1 - Estrutura de pontuação do GBTool..............................................................29

Figura 2 - Categorias de preocupação do CSTB ............................................................... 39

Figura 3 - Exemplo: diagrama de eficiência ambiental do edifício (BEE) .........................51

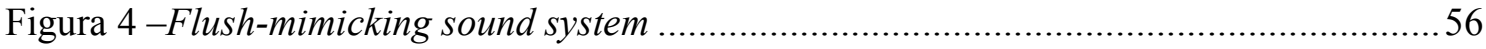

Figura 5 - Estrutura conceitual do CASBEE ................................................................ 71

Figura 6 - Desenvolvimento e declínio da legionella de acordo com a temperatura da água..83 


\section{LISTA DE TABELAS}

Tabela 2.1- Indicadores de sustentabilidade ambiental - GBTool 2002 .............................29

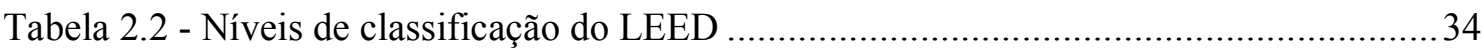

Tabela 2.3 - Exemplos de soluções economizadoras ....................................................... 43

Tabela 2.4 - Créditos referentes aos esforços para evitar a carga na infra-estrutura local no que

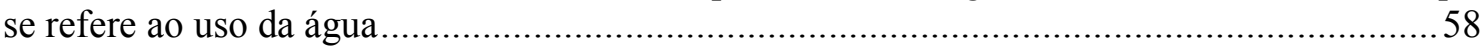

Tabela 2.5 - Avaliação comparativa entre os critérios referentes aos sistemas prediais hidráulicos e sanitários e ao uso da água para cada sistema de avaliação de sustentabilidade

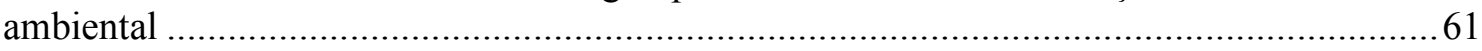

Tabela 3.1 - Valores para lançamento de efluentes tratados em galerias de águas pluviais ....91

Tabela 3.2 - Largura da faixa marginal de preservação permanente em função da largura do

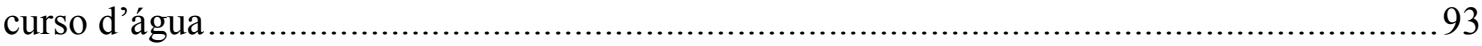

Tabela 3.3 - Intervalos apropriados para o nível de ruído ambiente, em $\mathrm{dB}(\mathrm{A})$, num recinto de edificação, conforme a finalidade mais característica de utilização desse recinto ................ 102

Tabela 3.4 - Cargas atuantes em aparelhos sanitários ................................................... 111

Tabela 3.5 - Impactos atuantes em tubulações aparentes .................................................. 111

Tabela 3.6 - Lista de verificação de ações de sustentabilidade ambiental para projeto dos sistemas prediais hidráulicos e sanitários em edifícios de escritórios ................................116 


\section{LISTA DE ABREVIATURAS E SIGLAS}

\begin{tabular}{|c|c|}
\hline ABNT & Associação Brasileira de Normas Técnicas \\
\hline ASHRAE & American Society of Heating, Refrigerating and Air Conditioning Engineers \\
\hline ASTM & American Society for Testing and Materials \\
\hline BEE & Eficiência Ambiental do Edifício \\
\hline BRE & Building Research Establishment \\
\hline BREEAM & Building Research Establishment Environmental Method \\
\hline CASBEE & Comprehensive Assessment System for Building Environmental Efficiency \\
\hline CIB & $\begin{array}{l}\text { International Council for Research and Innovation in Building and } \\
\text { Construction }\end{array}$ \\
\hline CONAMA & Conselho Nacional do Meio Ambiente \\
\hline CSTB & Centre Scientifique et Tecnique du Bâtiment \\
\hline DOE & United States Department of Energy \\
\hline FGBC & Florida Green Building Council \\
\hline GBC & Green Building Challenge \\
\hline $\mathrm{ICh}$ & Indicador de Consumo histórico \\
\hline iiSBE & International Initiative for Sustainable Built Environment \\
\hline JSBC & Japan Sustainable Building Consortium \\
\hline LEED & Leadership in Energy and Environmental Design \\
\hline PURA & Programa de Uso Racional da Água \\
\hline PCA & Programa de Conservação da Água \\
\hline QEB & Qualité Environnementale du Bâtiment \\
\hline $\mathrm{SMO}$ & Système de Management d'Operation \\
\hline USEPA & United States Environmental Protection Agency \\
\hline USGBC & U. S. Green Building Council \\
\hline WHO & World Health Organisation \\
\hline
\end{tabular}




\section{SUMÁRIO}

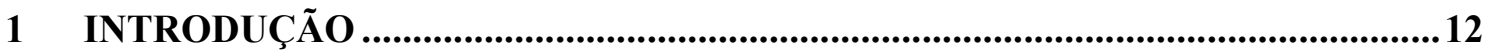

1.1 SUSTENTABILIDADE ......................................................................................................12

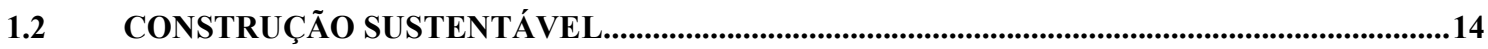

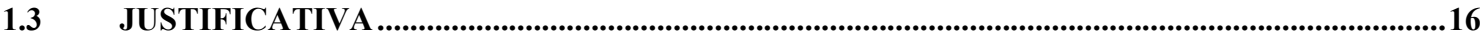

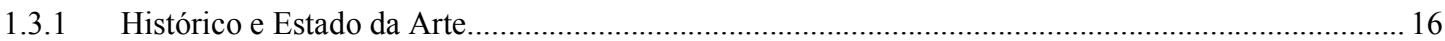

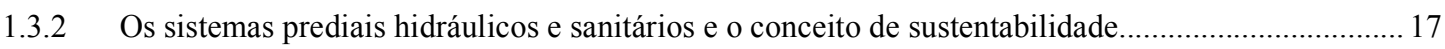

1.4 OBJETIVOS ……............................................................................................................................... 18

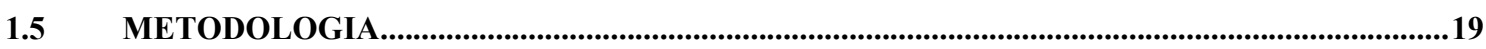

2 SISTEMAS DE AVALIAÇÃO DE SUSTENTABILIDADE DE EDIFÍCIOS: A AVALIAÇÃO DOS SISTEMAS PREDIAIS HIDRÁULICOS E SANITÁRIOS ...........21

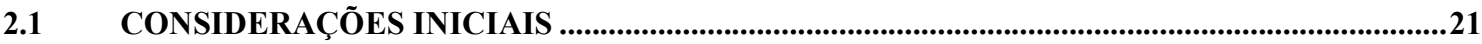

2.2 BUILDING RESEARCH ESTABLISHMENT ENVIRONMENTAL METHOD - BREEAM

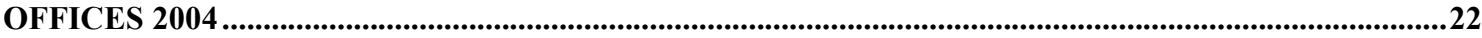

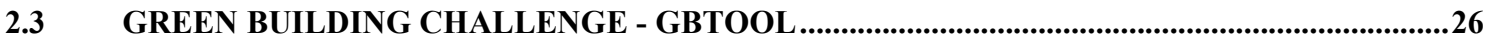

2.4 LEADERSHIP IN ENERGY AND ENVIRONMENTAL DESIGN - LEED................................32

2.5 CENTRE SCIENTIFIQUE ET TECNIQUE DU BÂTIMENT - CSTB RÉFÉRENTIEL DE

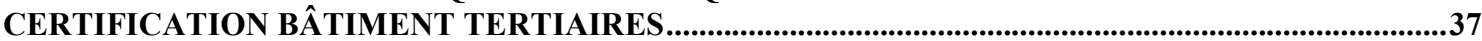

2.6 COMPREHENSIVE ASSESSMENT SYSTEM FOR BUILDING ENVIRONMENTAL

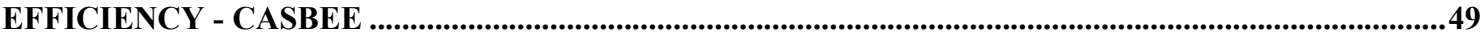

2.7 COMPARAÇÃO ENTRE OS CRITÉRIOS DE AVALIAÇÃO DOS SISTEMAS PREDIAIS HIDRÁULICOS E SANITÁRIOS E DO USO DA ÁGUA DOS SISTEMAS DE AVALIAÇÃO DE SUSTENTABILIDADE DE EDIFÍCIOS DE ESCRITÓRIOS ........................................................................60

2.8 CONSIDERAÇÕES SOBRE OS CRITÉRIOS REFERENTES AOS SISTEMAS PREDIAIS HIDRÁULICOS E SANITÁRIOS CONTEMPLADOS NOS MÉTODOS DE AVALIAÇÃO PESQUISADOS

.67

3 CRITÉRIOS DE AVALIAÇÃO DE SUSTENTABILIDADE AMBIENTAL DOS SISTEMAS PREDIAIS HIDRÁULICOS E SANITÁRIOS E DO USO DA ÁGUA EM EDIFÍCIOS DE ESCRITÓRIOS

3.1 CRITÉRIOS PROPOSTOS PELOS SISTEMAS DE AVALIAÇÃO PESQUISADOS CONTEMPLADOS NA DOCUMENTAÇÃO TÉCNICA E NA NORMALIZAÇÃO BRASILEIRA .........73

3.1.1 Confiabilidade, qualidade e manutenabilidade dos sistemas prediais hidráulicos e sanitários.............73

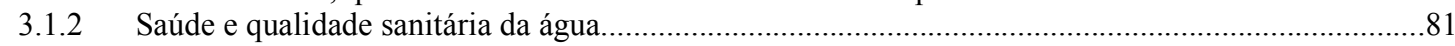

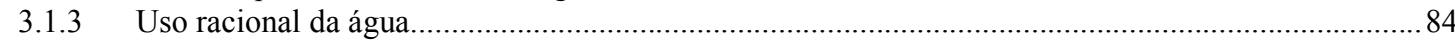

3.1.4 Carga na infra-estrutura local (drenagem pluvial)............................................................ 87

3.1.5 Carga na infra-estrutura local (tratamento de efluentes) .............................................................90 
3.1.6 Interferência do edifício em aqüíferos subterrâneos, áreas inundadas e cursos d'água......................92

3.1.7 Materiais componentes dos sistemas prediais hidráulicos e sanitários.............................................95

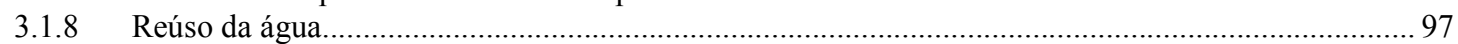

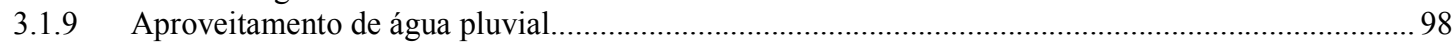

3.2 OUTROS CRITÉRIOS CONTEMPLADOS NA DOCUMENTAÇÃO TÉCNICA E NA

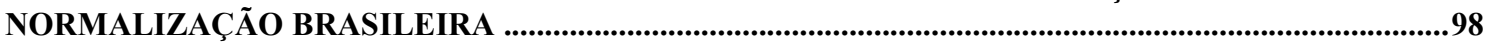

3.2.1 Confiabilidade, qualidade e manutenabilidade dos sistemas prediais hidráulicos e sanitários............99

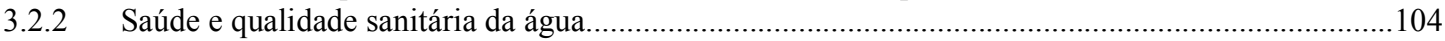

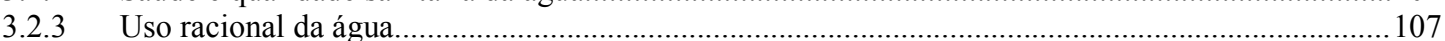

3.2.4 Materiais componentes dos sistemas prediais hidráulicos e sanitários.........................................109

3.3 LISTA DE VERIFICAÇÃO COM BASE NOS CRITÉRIOS DE AVALIAÇÃO DE SUSTENTABILIDADE AMBIENTAL DOS SISTEMAS PREDIAIS HIDRÁULICOS E SANITÁRIOS

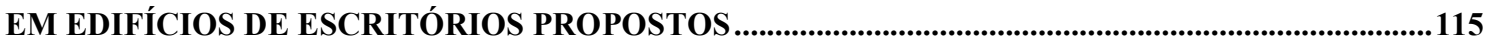

4 CONSIDERAÇÕES FINAIS .......................................................................... 121

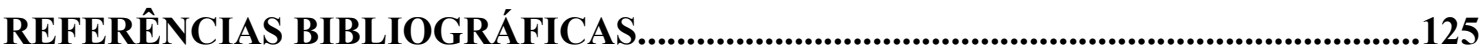

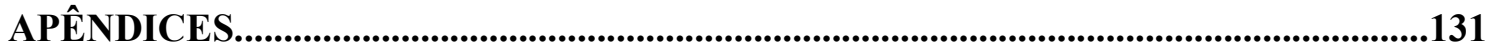




\section{INTRODUÇÃO}

\subsection{SUSTENTABILIDADE}

O início dos debates e discussões que acabaram por originar o termo desenvolvimento sustentável data da década de 1970. Em 1972 foi realizado um estudo que resultou na publicação de um relatório sobre os limites do crescimento no mundo. Nesse mesmo ano ocorreu a conferência das Nações Unidas em Estocolmo sobre o Ambiente Humano, ressaltando os crescentes problemas relacionados ao meio ambiente e sua exploração (VAN BELLEN, 2002).

O referido autor afirma também que o conceito de desenvolvimento sustentável é resultado de um processo de reavaliação da relação entre a sociedade e o meio ambiente, havendo diferentes maneiras de abordar o assunto. A definição clássica de desenvolvimento sustentável foi cunhada em 1987, pela World Comission on Environment and Devolopment: desenvolvimento econômico e social que atenda às necessidades da geração atual sem comprometer a habilidade das gerações futuras de atenderem a suas próprias necessidades.

Existem, no entanto, diferentes definições relacionadas à sustentabilidade, desenvolvimento sustentável e suas dimensões. Alguns autores consideram as dimensões

ambiental, social e econômica. Outros consideram ainda a dimensão cultural, geográfica ou política (VAN BELLEN, 2002; SACHS apud VAN BELLEN, 2002; SILVA, 2000; SILVA, 2003):

- dimensão ambiental: utilização do potencial dos diversos ecossistemas mantendo um nível mínimo de deterioração dos mesmos; 
- dimensão social: distribuição de renda de forma igual, diminuindo diferenças entre os diversos níveis da sociedade e melhorando as condições de vida das populações;

- dimensão econômica: realização do potencial econômico que facilite o acesso a recursos e oportunidades, aumentando a possibilidade de prosperidade a todos;

- dimensão cultural: modernização sem o rompimento da identidade cultural dos povos;

- dimensão geográfica: melhoria na qualidade de vida das pessoas e proteção à diversidade biológica através de uma melhor distribuição de assentamentos humanos e de atividades econômicas e

- dimensão política: estabilidade política, respeitando o direito de todos e criando mecanismos de incremento à participação da sociedade nas tomadas de decisão.

Do ponto de vista prático, segundo Silva (2003), a partir da década de 1980, iniciou-se a definição de metas ambientais, fazendo com que houvesse maior comprometimento com a questão do desenvolvimento sustentável em todo o mundo. Essas metas ambientais passaram a fazer parte de políticas de desenvolvimento de vários países, com a publicação da Agenda 21, em 1992.

Houve, a partir de então, a reinterpretação da Agenda 21 em diversos setores da sociedade, inclusive no setor de construção civil. Segundo a referida autora as interpretações mais relevantes no setor foram a Habitat II Agenda e a Agenda 21 on Sustainable Construction, de 1999. 


\subsection{CONSTRUÇÃO SUSTENTÁVEL}

A indústria da construção civil e o ambiente construído são duas peças-chave para o desenvolvimento sustentável, segundo o International Council for Research and Innovation in Building and Construction - CIB (1999). Segundo Silva (2003), a indústria da construção civil é a atividade humana com maior impacto sobre o meio ambiente, já que as etapas de execução, uso e operação, reforma, manutenção e demolição consomem recursos e geram resíduos que superam a maioria das outras atividades econômicas.

O conceito de construção sustentável aponta para diferentes prioridades e metas em diferentes locais ou países. Segundo CIB (1999), os países que apresentam uma economia mais desenvolvida se atêm à melhoria e implementação de novas tecnologias enquanto países em desenvolvimento focam em igualdade social e sustentabilidade econômica. A Agenda 21 on Sustainable Construction foi criada em 1999 com o intuito de ser um elo entre as Agendas existentes sobre o assunto e Agendas regionais para o ambiente construído e para o setor da construção civil.

Dessa forma, um dos objetivos da Agenda 21 on Sustainable Construction é a definição de uma série de conceitos de sustentabilidade, para que cada país ou região possa discutir e definir suas próprias prioridades. Dentro desse aspecto, CIB (1999) lista alguns pontos principais a serem discutidos para implementação de uma Agenda local:

- gestão e organização: engloba os aspectos técnicos da construção sustentável, além dos aspectos sociais, legais e econômicos;

- produto: pensar nas características do edifício ou produto para que sejam adequadas ao clima local, à cultura e tradições construtivas, além de serem adequadas ao estágio de desenvolvimento industrial do país ou região;

- consumo de recursos: medidas economizadoras de energia, redução das 
necessidades de transporte, redução no uso de recursos minerais, utilização de materiais renováveis e recicláveis, escolha do local e gestão do uso da água;

- verificação de impactos e cargas ambientais: impactos da construção do edifício na urbanização de uma área para as futuras gerações, além das cargas relacionadas à produção, operação e demolição do edifício e

- aspectos sociais, culturais e econômicos: contribuição para alívio da desigualdade social, criação de um ambiente de trabalho saudável e seguro, distribuição igualitária dos custos e benefícios sociais da construção, facilitação da criação de empregos, desenvolvimento dos recursos humanos, além de benefícios financeiros à comunidade.

Do ponto de vista prático, para encorajar a adoção da construção sustentável, medidas devem ser tomadas para que haja mudança na demanda de mercado. Uma maneira que se mostra válida para CIB (1999), é a implementação de sistemas de avaliação de sustentabilidade e certificação de edifícios. Tais métodos vêm sendo desenvolvidos e aplicados em diversos países europeus, além do Canadá, Estados Unidos, Hong Kong, Austrália e Japão (SILVA, 2003).

Segundo a referida autora, a base conceitual das primeiras metodologias que surgiram na década de 1990, para avaliação ambiental de edifícios, é o conceito de Análise do Ciclo de Vida. O objetivo era verificar e certificar que iniciativas ditas "verdes" de fato o eram, através da criação de edifícios mais duráveis, da utilização eficiente de recursos, do atendimento e da adaptabilidade às necessidades dos usuários e da possibilidade de reúso e reciclagem de componentes. 


\subsection{JUSTIFICATIVA}

\subsubsection{Histórico e Estado da Arte}

Segundo Silva (2003), o primeiro sistema de avaliação de sustentabilidade de edifícios a ser lançado foi o Building Research Establishment Environmental Method - BREEAM, do Reino Unido, em 1990. Outras iniciativas importantes são as seguintes:

- Leadership in Energy and Environmental Design - LEED, dos Estados Unidos;

- Green Building Challenge - GBTool, de um consórcio internacional;

- Hong Kong Building Environmental Assessment Method - HK-BEAM, de Hong Kong;

- PromisE Environmental Classification System for Buildings, da Finlândia;

- Centre Scientifique et Tecnique du Bâtiment - CSTB Référentiel de Certification de Bâtiment Tertiaires - CSTB, da França;

- National Australian Building Environment Rating Scheme - NABERS, da Austrália;

- Comprehensive Assessment System for Building Environmental Efficiency CASBEE, do Japão.

No Brasil, dentro do tema avaliação de sustentabilidade de edifícios, Silva (2003) elaborou a tese de Doutorado intitulada "Avaliação da Sustentabilidade de Edifícios de Escritórios Brasileiros: Diretrizes e Base Metodológica", defendida na Escola Politécnica da Universidade de São Paulo. Esse trabalho mostra a necessidade de elaboração de um método de avaliação que considere as condições e limitações brasileiras. Para tanto, foram definidos vários parâmetros de sustentabilidade ambiental que, através de um processo de julgamento de importância, realizado por vários profissionais da área, acabaram por produzir uma 
proposta inicial para criação de um método de avaliação de sustentabilidade ambiental de edifícios de escritórios brasileiros.

1.3.2 Os sistemas prediais hidráulicos e sanitários e o conceito de sustentabilidade

A definição de desenvolvimento sustentável da World Comission on Environment and Devolopment aponta para um desenvolvimento econômico e social capaz de atender as necessidades desta geração, não comprometendo o atendimento das necessidades das gerações futuras (SILVA, 2003). No setor da construção civil, segundo a referida autora, a sustentabilidade é "fornecer mais valor, poluir menos, ajudar no uso sustentado de recursos, responder mais efetivamente às partes interessadas, e melhorar a qualidade de vida presente sem comprometer o futuro".

Diversos estudos apontam a questão da escassez de água como grande problema para as gerações futuras. Do total de água existente na Terra, a parcela de água doce corresponde a apenas $2,5 \%$, dos quais, apenas $0,001 \%$ está disponível para consumo humano (SAUTCHÚK, 2004).

No Brasil, segundo a referida autora, existe um sério problema de distribuição de água no território. O país detém cerca de $12 \%$ da água doce do mundo, porém $80 \%$ deste total está localizado na Bacia Amazônica, região de baixa densidade populacional. May (2004) afirma que, em alguns estados brasileiros como Alagoas, Paraíba, Pernambuco, Sergipe e Rio Grande do Norte, a disponibilidade hídrica per capita não é suficiente para atender a demanda.

Dentro desse contexto de necessidade de otimização da utilização da água, os esforços para economizar água e para minimizar a geração de efluentes têm sua importância ressaltada. Segundo Sautchúk (2004), no que se refere a edifícios, é importante que seja avaliada a demanda de água necessária e o uso de fontes alternativas para atendimento de usos menos nobres, de modo a resguardar as fontes de suprimento de água existentes. 
A gestão do uso da água como estratégia de preservação deste recurso vem ao encontro do conceito de desenvolvimento sustentável, uma vez que pretende garantir disponibilidade de água para as gerações futuras e que, sem este recurso, não há possibilidade de vida na Terra.

Dentro deste contexto foi efetuada uma pesquisa bibliográfica dos principais métodos de avaliação de sustentabilidade ambiental de edifícios de escritórios existentes e dos critérios neles constantes referentes aos sistemas prediais hidráulicos e sanitários e ao uso da água. A partir disso são efetuadas propostas de itens sobre esse tema a serem considerados em um sistema de avaliação de edifícios de escritórios no Brasil.

\subsection{OBJETIVOS}

O objetivo principal do presente trabalho é a proposição de critérios de avaliação de sustentabilidade ambiental dos sistemas prediais hidráulicos e sanitários em edifícios de escritórios. Com isso, pretende-se incentivar as práticas de conservação da água no ambiente construído, além de ser uma contribuição para a aplicação dos conceitos de sustentabilidade ambiental no projeto e execução desses sistemas na construção civil brasileira.

Pretende-se chegar a uma lista de critérios de avaliação de sustentabilidade ambiental que possa ser utilizada por engenheiros, arquitetos, construtores, projetistas e demais envolvidos no setor, quando do projeto e execução (ou reforma) de sistemas prediais hidráulicos e sanitários de edifícios de escritórios. O objetivo é inserir conceitos relacionados à sustentabilidade ambiental aos projetos e uma maior preocupação com o uso e conservação da água no ambiente construído. 


\subsection{METODOLOGIA}

Para a proposição de critérios relacionados aos sistemas prediais hidráulicos e sanitários foi efetuada uma pesquisa bibliográfica dos seguintes métodos de avaliação de sustentabilidade ambiental de edifícios de escritórios:

- Building Research Establishment Environmental Method - BREEAM,

- Leadership in Energy and Environmental Design - LEED;

- Green Building Challenge - GBTool;

- Centre Scientifique et Tecnique du Bâtiment - CSTB Référentiel de Certification de Bâtiment Tertiaires - CSTB;

- Comprehensive Assessment System for Building Environmental Efficiency CASBEE.

Tais métodos de avaliação de sustentabilidade de edifícios de escritórios foram selecionados para fazer parte do presente trabalho por possuírem atualização recente, por estarem disponíveis em idiomas acessíveis e por mostrarem a realidade da construção civil em diferentes países.

A pesquisa contempla a descrição conceitual dos métodos estudados (como avaliam) e os parâmetros de sustentabilidade analisados por esses métodos (o quê avaliam), focando na avaliação de itens relacionados aos sistemas prediais hidráulicos e sanitários e ao uso da água. Tais itens foram então comparados e agrupados em categorias de desempenho, propostos no presente trabalho.

Os critérios de avaliação de sustentabilidade ambiental dos sistemas prediais hidráulicos foram então pesquisados na documentação técnica e normalização brasileira com 
o intuito de verificar as exigências e recomendações aplicáveis a edifícios de escritórios no Brasil. A partir dessa pesquisa bibliográfica foram verificados pontos pertinentes à sustentabilidade ambiental contemplados na documentação técnica e na normalização brasileira que não estavam contemplados nos métodos de avaliação estudados. O resultado final é uma lista de critérios de avaliação de sustentabilidade ambiental dos sistemas prediais hidráulicos e sanitários em edifícios de escritórios que engloba todos os requisitos estudados. 
2 SISTEMAS DE AVALIAÇÃO DE SUSTENTABILIDADE DE EDIFÍCIOS: A AVALIAÇÃO DOS SISTEMAS PREDIAIS HIDRÁULICOS E SANITÁRIOS

\subsection{CONSIDERAÇÕES INICIAIS}

Conforme destacado anteriormente a necessidade da avaliação do desempenho ambiental de edifícios surgiu quando se constatou que não havia meios de verificar se os edifícios intitulados "verdes", de fato o eram. E mais alarmante ainda foi a comprovação de que os edifícios que supostamente utilizavam os conceitos de construção ambientalmente sustentável, "freqüentemente consumiam mais energia que aqueles resultantes de práticas comuns de projeto e construção" (SILVA, 2003).

Os sistemas de avaliação de sustentabilidade de edifícios foram, em um primeiro momento, inspirados na prática de avaliação de impactos ambientais empregada em produtos industrializados. Para tal avaliação, a indústria utilizou o conceito de Análise do Ciclo de Vida que, segundo a referida autora, "é o procedimento de analisar formalmente a interação de um sistema (...) com o ambiente ao longo de todo o seu ciclo de vida, caracterizando o que se tornou conhecido como o enfoque do "berço ao túmulo"”. Assim, a análise do desempenho ambiental de edifícios é efetuada a partir das aplicações dos conceitos de análise do ciclo de vida à indústria da construção civil.

Segundo Baldwin apud Silva (2003), a análise do ciclo de vida proporciona um cunho mais científico à avaliação ambiental, embora haja limitações por ser este um procedimento bastante abrangente. A análise e quantificação do uso de energia e matéria e das emissões de um sistema, além da análise dos impactos relativos a estes usos durante todo o ciclo de vida, desde a extração até a disposição final, é bastante complexa. Apesar disso, segundo Silva 
(2003), há vantagens concretas, o que faz com que todos os métodos de avaliação tentem incorporar estes conceitos.

A referida autora destaca também que países como Reino Unido, Alemanha, Suécia, Dinamarca, Finlândia, Canadá, Áustria, França, Japão, Austrália e Estados Unidos possuem sistemas de avaliação de sustentabilidade de edifícios. Existem os sistemas orientados para o mercado, como o BREEAM (Reino Unido), LEED (Estados Unidos), CASBEE (Japão), CSTB (França), que possuem uma estrutura mais prática e por isso de mais fácil aplicação. Outros sistemas, como o GBTool (de um consórcio internacional), são orientados para pesquisa, apresentando uma metodologia mais abrangente para orientação de novos sistemas. Além desses, existem outros sistemas de avaliação de sustentabilidade ambiental de edifícios de escritórios, alguns derivados dos mesmos, outros não possuem atualização recente e/ou estão disponíveis em idiomas menos acessíveis.

\subsection{BUILDING RESEARCH ESTABLISHMENT ENVIRONMENTAL METHOD - BREEAM OFFICES 2004}

O BREEAM (Building Research Establishment Assessment Method) foi lançado em 1990, no Reino Unido, por pesquisadores do BRE (Building Research Establishment) e do setor privado (BALDWIN et al., 1998). O BREEAM objetiva mostrar caminhos para minimizar efeitos adversos dos edifícios nos ambientes local e global, além de promover um ambiente interno saudável e confortável.

Segundo os referidos autores, o método tem significativa penetração no mercado no Reino Unido, além de servir como base para métodos de avaliação de sustentabilidade ambiental de edifícios em outros países. Tanto a versão BREEAM 98 quanto a BREEAM 
Offices 2004 apresentam uma lista de verificação (checklist), da qual um número mínimo de itens deve ser atendido. A etapa posterior à lista de verificação é a contagem de créditos, que são ponderados, gerando como resultado um número. Este número possibilita o enquadramento do edifício em uma das classes de desempenho propostas pelo método. A avaliação é sempre realizada por avaliadores credenciados pelo BRE, órgão responsável pela especificação dos critérios e métodos de avaliação e por assegurar a qualidade do processo de avaliação utilizado.

O BREEAM possui uma estrutura de avaliação dividida em 9 categorias principais:

- Gestão;

- Saúde e conforto;

- Uso de energia;

- Transporte;

- Uso da água;

- Uso de materiais;

- Uso do solo;

- Ecologia local e

- Poluição.

Tendo em vista o escopo do presente trabalho, serão detalhadas as categorias "uso da água"; "gestão"; "poluição"; e "saúde e conforto". Na categoria "uso da água", a somatória de pontos pode chegar a 48 pontos de um máximo de 1062, porém estes números não revelam a importância relativa do item, já que há posteriormente uma ponderação. Segundo Dickie e Howard apud Silva (2003), “o critério de ponderação utilizado tem base consensual e resulta de trabalho conduzido pelo BRE”. Segundo a referida autora, a ponderação é resultado de um processo de consulta a profissionais no Reino Unido e é atualizada periodicamente. De uma 
maneira geral, desde o início da utilização do método, em 1990, o mesmo é constantemente revisado e estendido ou ampliado. A seguir serão detalhadas as categorias presentes no checklist para projeto do BREEAM Offices 2004 (BRE, 2003) que apresentam critérios de avaliação referentes aos sistemas prediais hidráulicos e sanitários e ao uso da água, além da pontuação máxima para atendimento dos critérios.

A) Categoria Gestão - pontuação máxima: 24 pontos.

- Especificação de ações consideradas como "melhores práticas" no que diz respeito à minimização de riscos de poluição de águas subterrâneas, cursos d'água e de sistemas municipais: 8 pontos na avaliação.

Outras áreas que não tratam diretamente dos sistemas prediais hidráulicos, mas que também os englobam de alguma maneira são avaliadas nesta categoria, como por exemplo, a provisão de um guia com informações para o administrador ou síndico do edifício. Este guia pode estar contido no Manual do Proprietário e equivale a 16 pontos na avaliação do método.

B) Categoria Saúde e conforto - pontuação máxima: 10 pontos.

- Sistemas de aquecimento de água projetados para minimizar o risco de contaminação por legionella Pneumophila ou ações que minimizem este risco.

C) Categoria Uso da água - pontuação máxima: 48 pontos.

- Consumo previsto:

- consumo previsto entre $3,15 \mathrm{~m}^{3}$ e $3,85 \mathrm{~m}^{3}$ por pessoa por ano: 8 pontos; 
- consumo previsto entre $1,05 \mathrm{~m}^{3}$ e $3,15 \mathrm{~m}^{3}$ por pessoa por ano: 16 pontos;

- consumo previsto menor que $1,05 \mathrm{~m}^{3}$ por pessoa por ano: 24 pontos;

É importante ressaltar que o baixo consumo deve ser consciente, atendendo às exigências dos usuários, sem que haja prejuízo para o desempenho dos sistemas prediais hidráulicos e sanitários.

- Medição de água:

- previsão de medidores de água que permitam monitoramento remoto cobrindo todo o suprimento do edifício: 8 pontos;

- Detecção de vazamentos:

- previsão de sistema de detecção de vazamentos (para maiores vazamentos), cobrindo os principais pontos: 8 pontos;

- Detectores de presença:

- previsão de detector de presença em todos os mictórios e bacias sanitárias: 8 pontos;

D) Categoria Poluição - pontuação máxima: 24 pontos.

- Previsão de sistema de aproveitamento de águas pluviais ou uso de técnicas sustentáveis de drenagem de modo a atenuar o escoamento superficial em, no mínimo, 50\% no período de pico, tanto para descarte em cursos naturais de 
água, como para descarte nos sistemas municipais de drenagem pluvial: 12 pontos;

- Previsão de sistemas de tratamento de efluentes no local, tais como filtração e separação de óleo: 12 pontos.

\subsection{GREEN BUILDING CHALLENGE - GBTOOL}

O Green Building Challenge (GBC) é um consórcio internacional que desenvolveu um método para avaliação de sustentabilidade de edifícios, o GBTool. O objetivo era a criação de um método para avaliação de edifícios que respeitasse diferentes técnicas e diferenças regionais (COLE; LARSSON, 2002).

Segundo Silva (2003), o GBC não fornece uma certificação de desempenho, pois pretende prover uma "base metodológica sólida e a mais científica possível, dentro das limitações do estado atual do conhecimento". A avaliação do desempenho ambiental de projetos está baseada em benchmarks, ou seja, é efetuada uma comparação com desempenhos de referência. Segundo GBC (2004), o projeto não pretende obter resultados imediatos, porém acredita que, no longo prazo, o impacto aparecerá na forma como os edifícios serão projetados.

O GBC 98 incluía 14 países e culminou com a Conferência de Vancouver, em outubro de 1998, quando 34 projetos foram avaliados. O GBC 2000 incluiu 18 países na Conferência da Holanda, examinando 36 projetos de edifícios. Em 2002, 16 países, incluindo o Brasil, participaram da Conferência do GBC 2002, na Noruega. Para facilitar a sua aplicação, a versão do GBC 2002 usou a plataforma Microsoft Excel (COLE; LARSSON, 2002). 
Segundo os referidos autores, o GBTool 2002 não incluiu nenhum avanço conceitual frente às versões anteriores. A ênfase foi dada no sentido de facilitar e automatizar as entradas de dados e o manuseio da ferramenta. O GBC pretende desenvolver uma segunda geração de sistemas de avaliação de edifícios, englobando diferentes prioridades, tecnologias, tradições construtivas e valores culturais. Até janeiro de 2001, o GBC era conduzido pela Natural Resources Canada. A partir dessa data, o iiSBE (International Initiative for Sustainable Built Environment) foi criado para assumir a administração e o desenvolvimento do mesmo.

Os objetivos do GBC e do desenvolvimento do GBTool 2002 são os seguintes (COLE; LARSSON, 2002):

- avançar no estado da arte nas metodologias de avaliação de desempenho ambiental;

- verificar constantemente os assuntos relacionados à sustentabilidade de modo a assegurar a sua relevância para os edifícios "verdes" em geral e para ajudar na estruturação de métodos de avaliação de desempenho ambiental de edifícios;

- organizar conferências que promovam trocas entre a comunidade de pesquisa de desempenho ambiental de edifícios e profissionais do meio e

- evidenciar a relação entre a avaliação do desempenho de edifícios e o desempenho ambiental de melhor nível.

A estrutura de avaliação é disposta em quatro níveis (SILVA, 2003):

- temas principais;

- categorias e áreas de desempenho;

- critérios e

- sub-critérios. 
Os temas principais avaliados pelo GBTool 2002 são os seguintes:

- Uso de Recursos;

- Cargas ambientais;

- Qualidade do Ar Interno;

- Qualidade dos Serviços;

- Aspectos econômicos e

- Gestão Pré-Ocupação.

Os três primeiros temas são obrigatórios e os três últimos, opcionais. Um sétimo tema (Transporte Regular) está presente, mas não operacionalizado na versão 2002. Cada um destes temas principais compreende várias categorias. Os níveis de critérios e sub-critérios são avaliados atribuindo-se valores entre (-2), que representa um desempenho insatisfatório e (5), que representa um desempenho-meta, perfeitamente alcançável com as tecnologias existentes. A pontuação dos critérios é obtida através da ponderação dos pontos dos sub-critérios, assim como a pontuação de cada categoria é obtida através da ponderação dos pontos de cada um dos critérios que a constituem. A pontuação de cada um dos temas principais é obtida através da ponderação dos pontos de suas categorias e, finalmente, a pontuação do edifício é obtida através da ponderação dos pontos de todos os temas principais, conforme esquema apresentado na figura 1: 


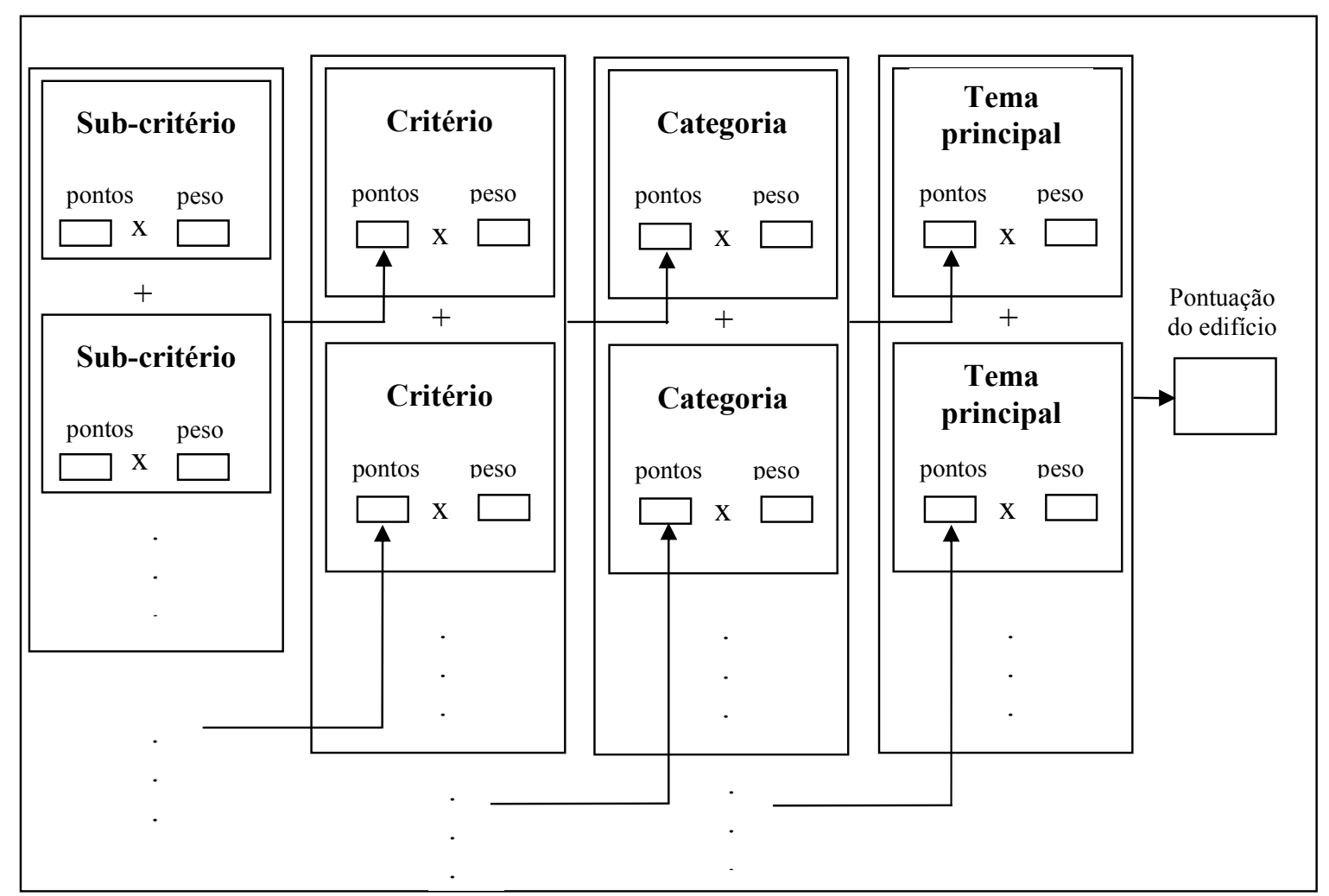

Figura 1 - Estrutura de pontuação do GBTool

São doze os indicadores de sustentabilidade ambiental avaliados, conforme tabela 2.1:

Tabela 2.1- Indicadores de sustentabilidade ambiental - GBTool 2002

\begin{tabular}{|l|l|}
\hline \multicolumn{2}{|c|}{ Indicadores de sustentabilidade } \\
\hline ESI-1 & Consumo total de energia incorporada \\
\hline ESI-2 & Consumo anual de energia primária incorporada \\
\hline ESI-3 & Consumo anual de energia primária para operação do edifício \\
\hline ESI-4 & Consumo anual de energia primária não-renovável para operação do edifício \\
\hline ESI-5 & Consumo anual de energia primária incorporada e para operação do edifício \\
\hline ESI-6 & Área de solo consumida pela construção do edifício e serviços relacionados \\
\hline ESI-7 & Consumo anual de água potável para operação do edifício \\
\hline ESI-8 & Uso anual de água cinza e água da chuva para operação do edifício \\
\hline ESI-9 & Emissão anual de gases de efeito estufa pela operação do edifício \\
\hline ESI-10 & Vazamento previsto de CFC-11 equivalente por ano \\
\hline ESI-11 & Massa total de materiais reutilizados empregados no projeto, vindos do próprio terreno ou de fontes externas \\
\hline ESI-12 & Massa total de novos materiais (não reutilizados) empregados no projeto, vindos de fontes externas \\
\hline
\end{tabular}

Fonte: Adaptado de SILVA (2003).

${ }^{1} \mathrm{O}$ termo energia incorporada se refere à energia utilizada para extração, processamento, manufatura e transporte de todos os materiais utilizados na construção do edifício, enquanto o termo energia para operação se refere à energia utilizada durante a operação do edifício, como em aquecedores, refrigeradores, iluminação e equipamentos (LARSSON, N.). Mensagem recebida por andreza@olimpiatur.com.br em 03 out. 2004. 
Três temas principais abordam o consumo de água (potável, de reúso ou da chuva) quais sejam, uso de recursos, cargas ambientais e qualidade dos serviços, conforme descrito a seguir.

Um ponto importante e que também envolve os sistemas prediais hidráulicos e sanitários, além de todos os demais sistemas prediais, é mencionado no tema Gerenciamento pré-ocupação. Este item da ferramenta de avaliação ambiental de edifícios GBTool, além de contemplar aspectos relativos à qualidade e controle, enfatiza a preocupação com a operação do edifício, destacando a importância de treinamento dos usuários e a provisão de projetos dos sistemas prediais de acordo com o que foi construído (as built).

\section{A) Uso de recursos}

Na categoria “consumo de água potável” é avaliado o volume total anual de água utilizada no edifício em estudo. A medida de desempenho é o consumo anual de água potável previsto por pessoa $\left(\mathrm{m}^{3} /\right.$ pessoa/ano), desconsiderando o consumo de água proveniente de práticas de reúso de água e de utilização de água pluvial, quando houver.

Para a sua determinação deve-se incluir toda a água potável utilizada:

- na descarga de bacias sanitárias e mictórios e em lavatórios públicos, menos a água de reúso;

- para outros fins sanitários;

- água potável empregada na operação de equipamentos do edifício;

- em cozinhas para fins comerciais (onde aplicável);

- em irrigação paisagística (menos o uso de água pluvial para irrigação). 
Os dados de consumo são derivados de especificações de uso de água em equipamentos que utilizam água (consumo/uso), da ocupação prevista, da freqüência de uso dos dispositivos que utilizam água e da estratégia de irrigação paisagística.

\section{B) Cargas ambientais}

A categoria de desempenho "efluentes líquidos" avalia a quantidade de efluentes líquidos originados pelo edifício em estudo. São avaliados o esgoto sanitário gerado e as águas pluviais coletadas, já que se considera a carga na infra-estrutura do local e a posterior carga nos sistemas ecológicos. A avaliação se dá através de dois critérios:

- destinação de água da chuva no local: para evitar carga sobre a infra-estrutura local nos períodos de pico e impactos no ecossistema local, como erosão de cursos naturais de água e transbordamento de estações de tratamento. A medida de desempenho é o volume de água de chuva, por unidade de área, que não será disposta no sistema municipal no período de 1 ano $\left(\mathrm{m}^{3} / \mathrm{m}^{2} / \mathrm{ano}\right)$;

- reúso de água no local: este critério leva em consideração as medidas para diminuição da quantidade de esgoto encaminhado à rede coletora local. O GBC (2002) cita que é preferível a utilização de tratamento biológico ao químico em termos de energia necessária e pelos impactos ambientais causados pelos produtos químicos. A medida de desempenho é o volume anual de esgoto (água cinza) que não será encaminhado ao sistema de tratamento de esgoto local $\left(\mathrm{m}^{3} / \mathrm{m}^{2} / \mathrm{ano}\right)$.

A categoria "Impactos ambientais no local e nas propriedades adjacentes" avalia medidas de projeto para reduzir impactos adversos nos edifícios vizinhos ou espaços adjacentes ao edifício. O critério de desempenho "emissões térmicas em lagos ou aqüíferos subterrâneos" é o critério que avalia as condições da água dentro desta categoria. É aplicável 
apenas em edifícios que utilizem fontes subterrâneas com bombas de calor. Esse critério avalia as medidas de precaução para reduzir emissões térmicas que possam causar mudanças na temperatura da água, o que limitaria o uso pelas propriedades adjacentes, ou seja, medidas apropriadas devem ser tomadas para manter as características de lagos e aqüíferos, permitindo sua utilização por outros.

C) Qualidade dos serviços

Dentro deste tema, a categoria "Manutenção de desempenho" trata da água e dos sistemas prediais hidráulicos através do critério de desempenho "Medição e monitoramento de desempenho". Esse critério de desempenho avalia os mecanismos para detecção de vazamentos e os procedimentos para consertar estes vazamentos através de um sub-critério de desempenho: "Provisão de sistema de detecção de vazamentos cobrindo todos os principais componentes dos sistemas de distribuição de água e gás". A medida de desempenho, no caso dos sistemas prediais hidráulicos e sanitários, é o projeto que possibilite a detecção de vazamentos dos sistemas hidráulicos.

\subsection{LEADERSHIP IN ENERGY AND ENVIRONMENTAL DESIGN - LEED}

O LEED foi desenvolvido pelo U. S. Green Building Council (USGBC) com o objetivo de disseminar os conceitos de construção ambientalmente sustentável para o mercado da construção civil nos Estados Unidos. A validade da certificação é de 5 anos. Após este período deve haver outra avaliação, com diferente foco: a operação e gestão do empreendimento (SILVA, 2003). 
$\mathrm{Na}$ versão 2.1 do LEED, não houve mudanças no que se refere aos níveis de desempenho, e sim apenas uma simplificação do processo de documentação. Este sistema de avaliação de sustentabilidade de edifícios é baseado em especificações de desempenho e a avaliação é realizada através da obtenção de créditos para o atendimento de critérios préestabelecidos. Segundo a referida autora, a referência é dada por "princípios ambientais e de uso de energia consolidados em normas e recomendações de organismos de terceira parte com credibilidade reconhecida, como a ASHRAE ${ }^{2}, \mathrm{ASTM}^{3}, \mathrm{USEPA}^{4}$ e o DOE ${ }^{5}$.

O LEED pretende promover a melhoria do bem-estar dos ocupantes do edifício, gerar retorno econômico e desempenho ambiental utilizando práticas reconhecidas e inovadoras, padrões e tecnologia (USGBC, 2002).

O critério mínimo é o cumprimento de 7 pré-requisitos. Após esta etapa, o edifício pode ser avaliado em 69 pontos de 6 áreas principais, quais sejam:

- Sítios sustentáveis (14 pontos);

- Uso eficiente de água (5 pontos);

- Energia e atmosfera (17 pontos);

- Materiais e recursos (13 pontos);

- Qualidade do ambiente interno (15 pontos) e

- Inovação e processo de projeto (5 pontos).

O resultado obtido pelo edifício é divulgado conforme apresentado na tabela 2.2.

\footnotetext{
${ }^{2}$ American Society of Heating, Refrigerating and Air Conditioning Engineers.

${ }^{3}$ American Society for Testing and Materials.

${ }^{4}$ United States Environmental Protection Agency.

${ }^{5}$ United States Department of Energy.
} 
Tabela 2.2 - Níveis de classificação do LEED

\begin{tabular}{|l|c|}
\hline Título a ser obtido pelo edifício & Pontuação \\
\hline LEED Certified & 26 a 32 pontos \\
\hline Silver & 33 a 38 pontos \\
\hline Gold & 39 a 51 pontos \\
\hline Platinum & 52 a 69 pontos \\
\hline
\end{tabular}

Fonte:USGBC (2002)

O LEED avalia a maneira como os sistemas prediais hidráulicos são projetados ou como ocorre o uso da água no edifício explicitamente nas áreas "sítios sustentáveis", "uso eficiente de água", "energia e atmosfera"; e indiretamente na área "inovação e processo de projeto", onde o edifício pode ser enquadrado se exceder o desempenho proposto pelo LEED para o uso eficiente da água ou se houver a criação de itens não propostos por este método, como campanhas de conscientização e educação dos usuários do edifício.

\section{A) Sítios sustentáveis}

Os tópicos que tratam da água para avaliação de sustentabilidade ambiental dentro desta área são os seguintes:

- controle de erosão e sedimentação: o objetivo é reduzir impactos negativos na qualidade do ar e da água. Um dos requisitos é a prevenção de sedimentação (no sistema de drenagem ou em córregos receptores). Este tópico é um prérequisito para a certificação no LEED;

- seleção do local: um dos requisitos é que o edifício esteja distante, no mínimo, 100 pés $(30,48 \mathrm{~m})$ de qualquer fonte de água, incluindo áreas inundadas, como pântanos;

- gerenciamento de águas pluviais - taxa e quantidade: a intenção é limitar a destruição e poluição de fluxos naturais de água através da administração do escoamento superficial. O requisito para obtenção do crédito é a apresentação de um plano de gerenciamento da água da chuva; 
- gerenciamento de águas pluviais - tratamento: a intenção é limitar a degradação de fluxos naturais de água, diminuindo o escoamento superficial, aumentando a infiltração local e eliminando contaminantes. O requisito para obtenção do crédito neste tópico é a construção de um sistema de tratamento da água da chuva, projetado para remoção de $80 \%$ dos sólidos suspensos totais e $40 \%$ de fósforo total, com base na média dos totais anuais de todas as precipitações menores ou iguais à precipitação de 24 horas, com período de retorno de 2 anos.

B) Uso eficiente de água

Os tópicos que tratam da água para avaliação de sustentabilidade ambiental são os seguintes:

- paisagismo eficiente com relação à água - redução de 50\% no consumo de água potável: a intenção é limitar ou eliminar o uso de água potável para irrigação paisagística. Existem duas maneiras possíveis, de acordo com o LEED: utilização de tecnologia de alta eficiência para irrigação ou a utilização de água da chuva ou reúso da água para o mesmo fim. A redução deve ser de, pelo menos, $50 \%$ do consumo de água potável quando comparada ao modelo convencional (sem utilização de tecnologia de alta eficiência ou de fontes alternativas de abastecimento) em qualquer uma das alternativas;

- paisagismo eficiente com relação à água - não utilizar água potável ou não prever sistema de irrigação: a intenção é a mesma do tópico anterior e a pontuação é somada à obtida no mesmo. O projeto que obtiver um ponto neste tópico, automaticamente terá um ponto no tópico anterior, já que o requisito é a utilização total de fontes alternativas para irrigação paisagística ou a não existência de sistema para este fim. Deve haver uma discussão completa do 
sistema de irrigação e no caso de não existência, deve haver uma explicação de como o projeto permite isso;

- inovações tecnológicas para as águas servidas: o objetivo é reduzir a geração de esgoto e a demanda de água potável, e ao mesmo tempo, aumentar a recarga do aqüífero local. O requisito para obtenção de pontuação é a utilização de menos água potável provida pelo município para o edifício (mínimo de 50\%) ou o tratamento de $100 \%$ do esgoto no local (alcançando um padrão de tratamento terciário). Em ambos os casos é necessária uma descrição de como será reduzido o consumo ou de como será realizado o tratamento do esgoto gerado no edifício;

- redução do uso de água - $20 \%$ de redução: a intenção é maximizar a eficiência no uso da água, reduzindo a carga nos sistemas públicos de tratamento de esgoto. O requisito é o emprego de estratégias que reduzirão em, pelo menos, $20 \%$ o uso de água quando comparado ao padrão calculado para o edifício (sem contar a água utilizada para irrigação) através do USA Energy Policy Act, de 1992.

- redução do uso de água - 30\% de redução: a intenção é a mesma do tópico anterior, ou seja, maximizar a eficiência no uso da água, reduzindo a carga nos sistemas públicos de tratamento de esgotos. O que muda é o requisito para obtenção da pontuação, que passa a ser uma redução de, no mínimo, 30\% no uso de água quando comparado ao padrão calculado para o edifício. Neste tópico a pontuação também é somada à do item anterior.

Uma estratégia sugerida pelo LEED nos dois últimos casos é o uso de dispositivos economizadores, como mictórios que não utilizam água, sensores de presença para reduzir a 
demanda de água e composting toilets. Também são sugeridos o reúso de água e a utilização de água da chuva para fins não potáveis, como na descarga de bacias sanitárias e mictórios, em sistemas mecânicos e usos seguros.

C) Energia e atmosfera

Apenas um dos tópicos trata da água para avaliação de sustentabilidade ambiental:

- medição e verificação: o objetivo é promover a otimização do desempenho de consumo de energia e água com o tempo. Um dos requisitos é a instalação de equipamentos de medição de água (sistemas prediais hidráulicos e de irrigação paisagística). É necessário também o desenvolvimento de um plano de medição e verificação (monitoramento dos dados). O LEED sugere que se faça a modelagem dos sistemas de energia e de água para que se tenha uma previsão da economia, além de projetar o edifício prevendo equipamentos que meçam o desempenho quanto ao consumo de água e energia.

\subsection{CENTRE SCIENTIFIQUE ET TECNIQUE DU BÂTIMENT - CSTB RÉFÉRENTIEL DE CERTIFICATION BÂTIMENT TERTIAIRES}

A certificação foi desenvolvida em 2002 pelo Centre Scientifique et Tecnique du Bâtiment (CSTB) com o intuito de atestar o desempenho ambiental de empreendimentos comerciais e ainda, segundo Cardoso (2003), "assegurar que seu desenrolar, da fase de programação até a de entrega da obra, se dá de modo controlado, garantindo que a qualidade esperada seja atingida". 
O processo da Certificação de "Empreendimento Comercial de Elevado Desempenho Ambiental" está em evolução e o material a que se teve acesso até o momento é o referencial “CSTB Projet Avril 2004 - Référentiel de Certification 'Bâtiment Tertiaires - Démarche $H Q E^{\circledR}$ - Bureau et Enseignement". Este material possui duas partes integrantes: o referencial SMO - Système de Management d'Operation ou Sistema de Gerenciamento do Empreendimento; e o referencial QEB - Qualité Environnementale du Bâtiment ou Qualidade Ambiental do Edifício.

O referencial SMO é uma peculiaridade da certificação do CSTB. Segundo Cardoso (2003), “o fato de certificar não somente o edifício, mas também o empreendimento, em todo o seu desenrolar, e não apenas em sua fase de projeto, como fazem outras certificações da mesma natureza, é uma primeira característica própria da certificação francesa”. Através do SMO serão declarados ações e fatores que permitirão que os objetivos referentes à qualidade ambiental do edifício se realizem durante todo o empreendimento. É através do SMO que as diretrizes de ações a serem tomadas são dadas aos consultores ambientais, engenheiros, arquitetos e a todos os profissionais ligados ao empreendimento (CSTB, 2004).

Cabe ao CSTB a realização de auditorias no SMO do empreendimento para verificar a viabilidade das ações pretendidas no QEB, parte da certificação que trata da qualidade ambiental do edifício. O referencial QEB contém as metas a serem alcançadas pelo empreendimento em questões ambientais, sanitárias e de conforto. Para tal, as ações a serem empreendidas são divididas em categorias de preocupações ambientais, sanitárias e de conforto, apresentadas na figura 2. 


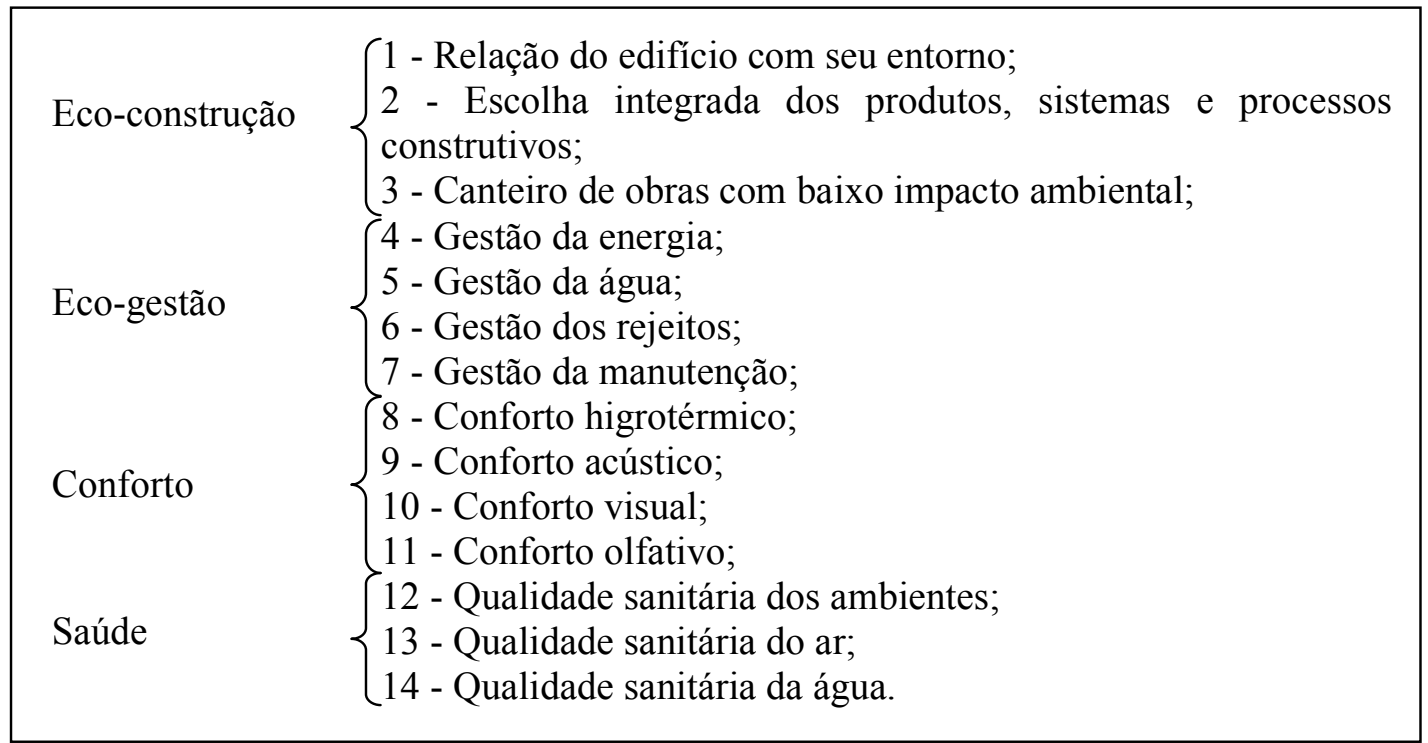

Figura 2 - Categorias de preocupação do CSTB

Destas 14 categorias, 4 devem atender, pelo menos, às exigências impostas pelo nível de desempenho Performant, e 3 devem atender, pelo menos, às exigências do nível de desempenho Très Performant. As outras 7 categorias devem atender às exigências do nível de desempenho Base.

Segundo Cardoso (2003), a certificação, ao estabelecer que todas as categorias apresentem um nível de desempenho igual ou superior à Base, acaba por impor que todas elas apresentem um desempenho igual ou superior ao normalizado ou igual ou superior ao correspondente às práticas usuais, já que é este o nível de exigência proposto no nível Base.

A hierarquização das categorias de preocupação ambiental (em Base, Performant e Très Performant) deverá ser justificada a partir da análise dos seguintes elementos (CSTB, 2004):

- política ambiental e a parte da QEB referente à operação do edifício (proteção ambiental, gestão patrimonial, conforto e saúde);

- necessidades dos usuários;

- opções funcionais do edifício; 
- análise do local, amparada por documentos como plantas, fotografias e documentação administrativa;

- inventário das exigências legais e regulamentares aplicáveis à operação e

- avaliação de custos de investimento e funcionamento.

O resultado final para o empreendimento é a certificação ou não, não havendo nenhum nível hierárquico (maior ou menor desempenho ambiental). As categorias que tratam do desempenho relacionado à água e aos sistemas prediais hidráulicos são detalhadas a seguir.

A) Relação do edifício: adequação para desenvolvimento urbano sustentável

O objetivo é assegurar que o projeto se insira de maneira adequada na gestão territorial do local (utilizando o conceito de desenvolvimento sustentável). A subcategoria é dividida em cinco itens e a água é citada em "Participação do esforço coletivo para racionalizar a exploração dos recursos locais disponíveis”. A característica desejada é a coerência com as políticas ambientais de energia, de saneamento e de água. O critério de avaliação é a análise dos dispositivos previstos para otimizar a exploração dos recursos locais disponíveis ou limitar os efeitos da implantação do edifício sobre as reservas existentes. Outro item trata das inundações e do tratamento dispensado à água pluvial. O critério é a otimização da retenção e infiltração da água da chuva, além da recuperação da água de escoamento superficial poluída e tratamento anterior ao despejo, em função da sua natureza.

Há ainda no Referencial QEB exemplos de dispositivos e ações que podem levar ao cumprimento dos itens acima. Para obter o nível Base na subcategoria "Adequação para desenvolvimento urbano sustentável”, o empreendedor deve fazer com que o edifício atenda 3 dos 5 itens acima mencionados. Para obtenção do nível Performant, 4 dos 5 itens devem ser 
atendidos. $\mathrm{O}$ referencial ainda menciona que os itens atendidos devem ter coerência com o que foi planejado no SMO.

B) Escolha integrada dos produtos, sistemas e processos construtivos.

Esta categoria diz respeito a todos os sistemas construtivos de um edifício e seus componentes, inclusive os sistemas prediais hidráulicos. Nela são analisados durabilidade, adaptabilidade, acessibilidade, impactos ambientais da obra e impactos sanitários dos produtos.

No que diz respeito à água, a subcategoria "Escolha dos produtos da construção de modo a limitar os impactos ambientais da obra" cita a norma francesa NF P01-010, relativa a cargas ambientais dos produtos da construção (sua contribuição a diferentes impactos ambientais, inclusive emissões poluentes na água e o volume consumido de água).

O empreendedor deve fazer um cálculo da carga ambiental sobre recursos energéticos, não energéticos, mudanças climáticas, acidificação atmosférica e dejetos sólidos e ainda separar a obra em duas partes (gros ceuvre e second $\propto u v r e^{6}$ ). De acordo com as ações e escolhas e com os cálculos a serem realizados, há o atendimento dos critérios propostos e o enquadramento em um dos níveis (Base, Performant ou Très Performant).

C) Canteiro de obras com baixo impacto ambiental:

Esta categoria interage também com a categoria "Gestão da água" na subcategoria "Redução de danos, poluentes e consumo de recursos do canteiro". Um de seus requisitos é a limitação da poluição da água, do ar e do subsolo. Existem ainda no Referencial exemplos de ações para limitar a poluição, como a utilização de produtos menos tóxicos; etiquetagem para identificação dos reservatórios de água; controle e coleta de efluentes, etc.

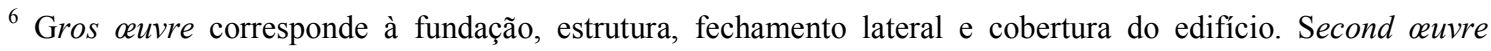
corresponde aos sistemas prediais hidráulicos, sanitários, elétricos, isolamento térmico, acabamentos, etc. (GLOSSAIRE, 2005).
} 
Outro requisito é a limitação do consumo dos recursos energia e água. O Referencial também cita exemplos, como o uso de dispositivos para economizar água potável.

Para alcançar o nível Base, um dos 3 requisitos desta subcategoria deve ser atendido. Para o nível Performant, 2; e, para o nível Très Performant, 3.

D) Gestão da água.

O objetivo desta categoria é limitar o uso deste recurso natural, os riscos potenciais de poluição e de inundação. Para tanto são vistos os seguintes aspectos:

- uso de água potável;

- gestão das águas pluviais e

- esgotamento sanitário.

O Referencial ressalta ainda a importância da exploração racional dos recursos disponíveis e a otimização da quantidade de água consumida para os diferentes usos. A categoria "Gestão da água" interage com o SMO ao tratar da transmissão das informações necessárias aos usuários para a perfeita utilização dos equipamentos economizadores e precauções a serem tomadas.

- Redução do consumo de água potável: o Referencial sugere quatro maneiras de economizar água potável dentro desta subcategoria:

- através do uso de água de qualidade inferior quando o uso assim permitir. O aproveitamento de água pluvial é citado e enfatiza-se o benefício dessa prática ao sistema de drenagem de águas pluviais local; 
- através do uso de dispositivos economizadores de água (de acordo com a realidade de utilização do edifício);

- através da sensibilização dos usuários e

- através do monitoramento do consumo de água a fim de evitar desperdícios e vazamentos.

Há alguns itens a serem atendidos:

- redução das pressões maiores que 3 bars $(300 \mathrm{kPa})$;

- otimização do consumo de água potável: aqui há dois níveis que poderão ser alcançados. No primeiro, devem ser identificadas as atividades consumidoras de água, os pontos de consumo e a utilização de equipamentos economizadores de água. No segundo e mais aprofundado, além das ações do primeiro nível, ainda há o cálculo de consumo de cada ponto de utilização e uma previsão de economia anual de água potável com o uso de equipamentos economizadores de água e

- limitação do uso de água potável: através da utilização de água não potável para usos que não requerem água com tal qualidade.

São citados, de forma indicativa, exemplos de soluções economizadoras (tabela 2.3):

Tabela 2.3 - Exemplos de soluções economizadoras

\begin{tabular}{|c|c|}
\hline Uso & Solução economizadora de água \\
\hline \multirow[t]{2}{*}{ Bacia sanitária } & Volume de descarga inferior a 71 e de duplo comando \\
\hline & Utilização de águas pluviais \\
\hline \multirow{3}{*}{ Lavatório } & Torneira com fechamento automático \\
\hline & Torneira com sensor de presença \\
\hline & Intervenção a fim de limitar a vazão de uso \\
\hline Chuveiro & Intervenção a fim de limitar a vazão de uso \\
\hline $\begin{array}{l}\text { Irrigação de espaços verdes } \\
\text { e limpeza de área comum }\end{array}$ & Utilização de águas pluviais \\
\hline
\end{tabular}


Há ainda uma nota indicativa de consumo de água em edifícios de escritórios, onde o valor apresentado é de 20 a 30 1/dia/funcionário. Segundo Cardoso (2006), este valor considera apenas a água para consumo humano, não considerando torres de resfriamento, por exemplo (informação pessoal) ${ }^{7}$.

- Otimização da gestão de águas pluviais

O anexo A.1 do SMO destaca que a gestão inteligente das águas pluviais é "condicionada pelo conhecimento do contexto de operação: rural ou urbano, densidade, potencial pluviométrico, redes existentes, natureza da água, poluidores potenciais, usos, etc." (CSTB, 2004). Dentro da subcategoria “Otimização da gestão de águas pluviais”, existem três itens a serem tratados:

- gestão da retenção: o nível de desempenho Base é obtido quando a vazão é mantida ou seu valor fica menor que o inicial. O nível Très Performant é obtido com uma vazão inferior a uma vazão correspondente a uma impermeabilização de 30\% da superfície;

- gestão da infiltração: o nível Base é obtido quando o coeficiente de impermeabilização do solo é de $40 \%$ a $80 \%$ e, para áreas fortemente urbanizadas, uma otimização do coeficiente de impermeabilização menor que $2 \%$. O nível Performant é obtido quando o coeficiente de impermeabilização do solo é de $20 \%$ a $40 \%$ e, para áreas fortemente urbanizadas, uma otimização do coeficiente de impermeabilização de 2\% a 10\%. Por fim, o nível Très Performant é obtido quando o coeficiente de impermeabilização do solo é menor que $20 \%$ e, para

\footnotetext{
${ }^{7}$ CARSOSO, F.F. Mensagem recebida por andreza@olimpiatur.com.br em 17 jan. 2006.
} 
áreas fortemente urbanizadas, uma otimização do coeficiente de impermeabilização maior que $10 \% \mathrm{e}$

- gestão das águas superficiais poluídas: o nível Base é obtido de acordo com as disposições tomadas para recuperar águas superficiais potencialmente poluídas e do tratamento em função de sua natureza antes do descarte.

E) Gestão da manutenção: esta categoria objetiva garantir a permanente manutenção do desempenho ambiental e sanitário do empreendimento. Segundo Cardoso (2003), esta categoria visa destacar a "importância de se conceber um edifício de modo que seu uso, sua manutenção e sua limpeza sejam facilitados".

- Manutenção do desempenho dos sistemas de gestão de água: simplicidade de concepção, meios para assegurar o desempenho e facilidade de acesso. Os critérios para enquadramento em cada um dos níveis são:

- Base: se na categoria "Gestão da água” foi obtido o nível Très Performant, o mínimo aceitável é que duas das três características acima (simplicidade de concepção, meios para assegurar desempenho e facilidade de acesso) sejam atendidas. Ou seja, o edifício não poderá, na subcategoria "Manutenção do desempenho dos sistemas de gestão de água", obter o nível Base. Se na categoria "Gestão da água" o empreendimento não obteve o nível Très Performant, apenas uma das características tem que ser atendida para obtenção do nível Base;

- Performant: duas das características devem ser atendidas e

- Très Performant: as três características devem ser atendidas. 
F) Qualidade sanitária da água: trata da qualidade da água destinada ao consumo humano, que deve respeitar os critérios de potabilidade e de adequação a certos parâmetros de uso. Segundo Cardoso (2003), esta categoria pretende assegurar a qualidade dos sistemas prediais, limitando riscos sanitários.

A certificação cita os cinco principais elementos que contribuem para a alteração microbiológica ou química da água no sistema:

- alteração de materiais;

- ligações acidentais;

- retorno de água;

- pouco controle do funcionamento hidráulico e da temperatura e - patologias como corrosão e incrustação.

Para garantir que alterações na qualidade da água não ocorram, as seguintes subcategorias são propostas pela certificação francesa:

- Qualidade e durabilidade dos materiais empregados nos sistemas prediais:

- escolha dos materiais conforme a regulamentação sanitária: todos os componentes dos sistemas prediais hidráulicos devem ter obtido uma autorização de conformidade sanitária (ACS) de acordo com a regulamentação francesa de 29 de maio de 1997;

- escolha de materiais compatíveis com a natureza da água distribuída: o emprego dos materiais componentes dos sistemas prediais hidráulicos não deve interferir nas condições físico-químicas da água a ser consumida. A certificação ainda cita alguns parâmetros 
que devem ser assegurados de acordo com o emprego de materiais como o cobre, PVC, aço galvanizado, etc.;

- respeito às normas que se referem aos materiais utilizados.

- Organização e proteção dos sistemas prediais hidráulicos: o objetivo desta subcategoria é que a concepção proposta assegure que os sistemas prediais que transportam água potável sejam claramente distinguidos de outros sistemas (por exemplo, do sistema predial de águas pluviais, de água de reúso ou de água proveniente de outras fontes alternativas como poços), reduzindo riscos de ligação acidental e contaminação da água potável transportada.

- separação dos sistemas prediais que transportam água potável de sistemas que transportam água não-potável: usar diferentes cores para identificação dos sistemas, conforme Guide Tecnique $\mathrm{n}^{\circ} 1$ de 29 de janeiro de 1993. No caso de utilização de uma fonte não autorizada, deve haver separação total dos sistemas para que não ocorram conexões cruzadas;

- proteção das conexões dos diferentes sistemas.

- Controle da temperatura nos sistemas prediais hidráulicos: esta subcategoria visa minimizar riscos relacionados à legionella Pneumophila e a acidentes com queimaduras. Segundo o CSTB (2004), para inibir o desenvolvimento da bactéria, é interessante que as temperaturas sejam superiores a $50^{\circ} \mathrm{C}$, o que aumenta os riscos de ocorrência de acidentes envolvendo queimaduras. A intenção é conciliar os dois objetivos que se contradizem: 
- isolar o sistema predial de água fria do sistema predial de água quente;

- manter todo o sistema predial de água quente a uma temperatura ótima: em todos os pontos a temperatura deve estar acima de $50^{\circ} \mathrm{C}$, exceto nas duchas, onde a temperatura deve estar limitada a $50^{\circ} \mathrm{e}$ - controle da manutenção da temperatura: ter sistema de controle e gestão.

- Controle de tratamentos anti corrosão e anti incrustação: o objetivo é garantir a higiene dos sistemas prediais hidráulicos:

- otimização do tratamento anti corrosão e/ou anti incrustação: adequação do tratamento à natureza da água e aos materiais componentes dos sistemas prediais hidráulicos;

- controle do desempenho dos tratamentos anti corrosão e anti incrustação: emprego de tubulação e torneiras para medição do desempenho dos tratamentos.

No caso dessa categoria, para todos os itens propostos dentro de cada subcategoria, há apenas a possibilidade de enquadramento ou não. Dessa forma, ou o empreendimento atende ao proposto em cada um dos itens ou não, não existindo neste caso os níveis Base, Performant ou Trés Performant. 


\subsection{COMPREHENSIVE ASSESSMENT SYSTEM FOR BUILDING} ENVIRONMENTAL EFFICIENCY - CASBEE

O Comprehensive Assessment System for Building Environmental Efficiency (CASBEE) é um método desenvolvido no Japão pelo Japan Sustainable Building Consortium - JSBC, e apresenta quatro ferramentas de avaliação ambiental:

- 0: avaliação pré-projeto;

- 1: projeto para o ambiente (Dfe);

- 2: certificação ambiental e

- 3: avaliação pós-projeto.

Utiliza o conceito de Eficiência Ambiental do Edifício (BEE) para tornar claros os resultados da avaliação e tornar mais simples a sua divulgação (JSBC, 2003). O BEE é resultado da seguinte divisão:

$$
\mathrm{BEE}=\frac{\text { Qualidade e desempenho ambiental do edifício }}{\text { Cargas ambientais geradas pelo edifício }}
$$

Para mensurar cargas ambientais e qualidade, é proposto o uso do conceito de limite hipotético para avaliar sistemas fechados (que seria o limite do terreno). Com esse conceito é possível definir cargas ambientais do edifício (impactos negativos que se estendem para fora do limite hipotético do sistema fechado) e qualidade e desempenho ambiental (melhoria na qualidade de vida dos usuários).

As categorias e subcategorias referentes a desempenho e qualidade são:

Q-1: Ambiente interno:

1. Ruído e acústica;

2. Conforto térmico;

3. Iluminação e 
4. Qualidade do ar.

Q-2: Qualidade dos serviços:

1. Funcionalidade, aconchego;

2. Durabilidade e confiabilidade e

3. Flexibilidade e adaptabilidade.

Q-3: Ambiente externo ao terreno:

1. Manutenção e criação de ecossistemas;

2. Paisagismo e

3. Características locais e cultura.

As categorias e subcategorias referentes à redução das cargas ambientais geradas pelo edifício são:

LR-1: Energia:

1. Carga térmica do edifício;

2. Utilização de energia natural;

3. Eficiência dos sistemas prediais e

4. Operação eficiente.

LR-2: Recursos e materiais:

1. Água e

2. Uso de materiais de baixa carga ambiental.

LR-3: Ambiente externo ao terreno:

1. Poluição do ar;

2. Ruídos e odores;

3. Acesso à ventilação;

4. Acesso à iluminação; 
5. Efeito ilha de calor e

6. Carga na infra-estrutura local.

A estrutura de avaliação e a apresentação de resultados do CASBEE derivam do GBTool, sendo que cada item avaliado recebe uma pontuação em termos de qualidade e desempenho e de redução das cargas ambientais. A seguir, ocorre a ponderação dentro da categoria correspondente (SILVA, 2003).

Segundo a referida autora, os resultados são comunicados na forma de valores numéricos, em gráficos de radar, colunas e através do diagrama de eficiência ambiental do edifício (figura 3), sendo o desempenho ambiental do edifício classificado em Superior (S), A, $\mathrm{B}^{+}, \mathrm{B}^{-}$ou $\mathrm{C}$.

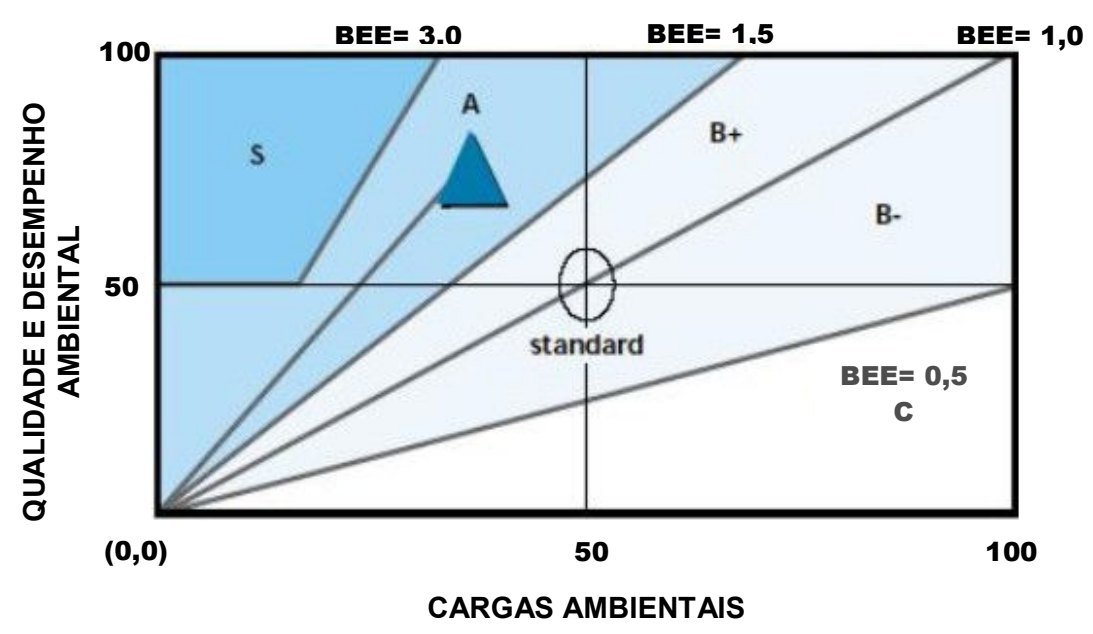

Figura 3 - Exemplo: diagrama de eficiência ambiental do edifício (BEE) Fonte: Adaptado de JSBC (2003).

O tratamento dispensado à água e aos sistemas prediais hidráulicos e sanitários pelo CASBEE na ferramenta Dfe (ferramenta de projeto para o ambiente) é apresentado a seguir. Esta ferramenta visa avaliar edifícios novos e auxiliar na melhoria da eficiência ambiental dos edifícios na etapa de projeto. 
As categorias e subcategorias referentes a desempenho e qualidade que tratam do uso da água e dos sistemas prediais hidráulicos e sanitários são as seguintes:

A) Qualidade dos serviços:

A.1) Durabilidade e confiabilidade

- Vida útil dos componentes:

Um dos itens é o intervalo de renovação para equipamentos e serviços necessários ao funcionamento do edifício e trata do desempenho dos equipamentos e serviços necessários ao funcionamento de edifícios de escritórios, como transformadores e receptores de energia, geradores, boilers, chillers, equipamentos de ar condicionado, reservatórios e sistemas elevatórios de água, etc.

O desempenho esperado é dividido em cinco níveis, em função do intervalo de renovação (tempo que levará até que o equipamento tenha que ser reformado ou substituído por outro):

$$
\begin{aligned}
& 1 \text { - intervalo de renovação de } 7 \text { anos; } \\
& 2 \text { - intervalo de renovação de } 7 \text { a } 15 \text { anos; } \\
& 3 \text { - intervalo de renovação de } 15 \text { anos; } \\
& 4 \text { - intervalo de renovação de } 15 \text { a } 30 \text { anos; } \\
& 5 \text { - intervalo de renovação de } 30 \text { anos ou superior. }
\end{aligned}
$$

- Confiabilidade

Um de seus itens trata do abastecimento de água e drenagem, avaliando os seguintes aspectos: 
- uso de equipamentos economizadores de água;

- sistemas prediais hidráulicos projetados de forma que não fiquem inoperantes na ocorrência de um desastre (terremotos, por exemplo), ou seja, deve ser prevista a separação física entre os sistemas;

- previsão de fossa para armazenamento de esgoto sanitário para o caso da rede de coleta pública estar fora de funcionamento após um desastre;

- previsão de dois reservatórios de água, sendo um deles, elevado;

- planejamento de uso de água de fontes alternativas (nascentes, água de chuva, reúso de água, etc.);

- previsão de um tanque para armazenamento de água pluvial para prover água na ocorrência de um desastre e

- o edifício deve ser equipado com sistema de filtragem simples que permita o uso de água pluvial para fins potáveis na ocorrência de um desastre.

O desempenho esperado é classificado apenas nos níveis 3, 4 e 5, sendo que os níveis 1 e 2 não existem, ou seja, não são aplicáveis a este item:

1 - não aplicável;

2 - não aplicável;

3 -aplicável a 1 aspecto dos citados anteriormente;

4 - aplicável a 2 aspectos dos citados anteriormente e 5 - aplicável a 3 ou mais aspectos dos citados anteriormente. 
A.2) Flexibilidade e adaptabilidade

- Adaptabilidade das Facilidades:

Um dos requisitos é a facilidade de reformas nos sistemas prediais de água fria, quente e de esgoto sanitário. De acordo com as características dos sistemas prediais hidráulicos, os seguintes níveis podem ser alcançados:

1 - a tubulação não pode ser substituída sem danificar os elementos estruturais (vigas, pilares e alvenaria estrutural);

2 - em alguns casos a tubulação pode ser trocada sem danificar elementos estruturais, com o uso de luvas, porém este método não é aplicado a todos os tubos;

3 - foram previstos espaços para reforma de modo que toda a tubulação possa ser substituída sem danificar elementos estruturais; 4 - tubulação embutida em dutos ou no forro, de modo que toda a tubulação possa ser substituída sem danificar elementos estruturais ou acabamentos e

5 - sistemas isolados e outras medidas que permitam fácil substituição da tubulação sem danificar acabamentos.

As categorias e subcategorias referentes à redução das cargas ambientais geradas pelo edifício e que tratam do uso da água e dos sistemas prediais hidráulicos e sanitários são as seguintes:

A) Recursos Materiais: 
A.1) Água:

- Economia de água: avalia os métodos para economizar água instalados no edifício, sendo os seguintes os níveis de classificação:

1 - não há sistemas para economizar água;

2 - não aplicável;

3 - a maioria das torneiras são equipadas com dispositivos economizadores;

4 - além de dispositivos economizadores nas torneiras, uso de outros equipamentos economizadores, como bacias sanitárias com descarga de volume reduzido ou dual-flush e flush-mimicking sound system e 5 - não aplicável.

O flush-mimicking sound system é um dispositivo utilizado no Japão devido a um hábito peculiar de algumas mulheres naquele país que costumam acionar a descarga da bacia sanitária enquanto a utilizam. Segundo Yoshizawa (2006), este hábito gera um grande desperdício de água em edifícios comerciais e de escritórios, por isso alguns empreendedores prevêem a instalação de um dispositivo que emite um ruído similar ao do de fluxo de água, conforme ilustrado na figura 4 (informação pessoal) $)^{8}$.

${ }^{8}$ YOSHIZAWA, N. CASBEE information desk. Mensagem recebida por andreza@olimpiatur.com.br em 18 jan. 2006. 


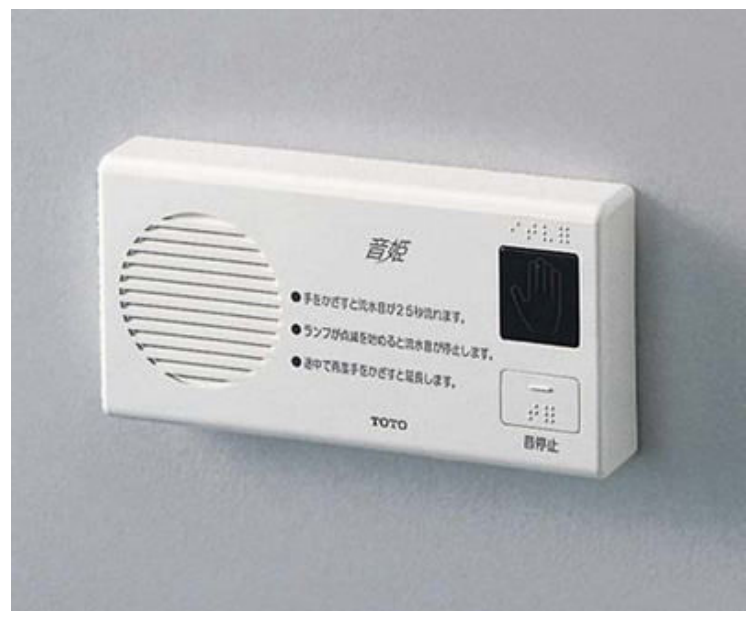

Figura 4-Flush-mimicking sound system Fonte: Yoshizawa (2006)

- Aproveitamento de água pluvial e reúso de água:

Um dos requisitos é a avaliação dos sistemas de utilização de água pluvial. Os níveis de classificação são os seguintes:

1 - não aplicável;

2 - não aplicável;

3 - não há sistema de uso da água pluvial;

4 - há sistema de uso da água da pluvial (com taxa menor que $20 \%$ ) e 5 - uso da água da pluvial de, no mínimo $20 \%$.

O cálculo da taxa de uso da água pluvial é efetuado pela seguinte fórmula:

Taxa de uso da $=\underline{\text { Volume previsto de uso de água pluvial }}$ água da chuva $\quad$ Volume total previsto de uso de água

Onde o volume total previsto de uso de água inclui a água potável e a água pluvial a ser utilizada no edifício. 
Outro requisito é a avaliação do sistema de reúso da água do edifício, sendo que a classificação se dá nos seguintes níveis:

1 - não aplicável;

2 - não aplicável;

3 - não há sistema de reúso da água;

4 - uso de águas cinza e

5 - uso de águas cinza e previsão de sistema de reúso de águas negras.

B) Ambiente externo ao terreno:

B.1) Efeito "ilha de calor": cita-se nessa subcategoria apenas uma das medidas de contenção da formação das "ilhas de calor" que é a previsão de espaços verdes e de um corpo d'água no terreno. Dentro deste item principal, um dos itens secundários é o uso de irrigação utilizando água pluvial e de esgoto (reúso da água).

B.2) Carga na infra-estrutura local: o edifício impõe cargas na infra-estrutura do local onde o mesmo se insere, no que se refere ao abastecimento de água e de energia, tratamento de esgoto, tráfego e transporte, disposição de lixo e drenagem pluvial. Como o uso de energia e de água são tratados respectivamente em LR-1 Energia e LR-2 - Recursos e materiais, as cargas na infra-estrutura local avaliadas nesse item são as seguintes: 
- de drenagem;

- de tratamento de esgoto;

- de transporte e

- de tratamento de lixo.

Para o enquadramento do projeto em um dos níveis há uma tabela de requisitos a serem atendidos, dependendo do tipo do edifício. Para edifícios de escritório, os requisitos referentes à carga provocada pelo uso da água são os relacionados na tabela 2.4:

Tabela 2.4 - Créditos referentes aos esforços para evitar a carga na infra-estrutura local no que se refere ao uso da água

\begin{tabular}{|l|c|c|c|}
\hline \multirow{2}{*}{ Esforços } & \multicolumn{3}{c|}{ Nível dos esforços } \\
\cline { 2 - 4 } & Alto & Baixo & Nenhum \\
\hline I. Esforços para reduzir cargas de drenagem pluvial & \multicolumn{3}{|c|}{} \\
\hline 1) Medidas para encorajar a percolação da água no solo & 2 & 1 & 0 \\
\hline 2) Medidas para detenção temporária da água da chuva & \multicolumn{3}{|c|}{ Obrigatório } \\
\hline 3) Outro & 2 & 1 & 0 \\
\hline II. Esforços para reduzir cargas de tratamento de esgoto & \multicolumn{3}{|c|}{} \\
\hline $\begin{array}{l}\text { 4) Observação de padrões de qualidade da água descartada } \\
\text { observando leis locais (quando o descarte é em rede pública) }\end{array}$ & \multicolumn{2}{|c|}{0} \\
\hline $\begin{array}{l}\text { 5) Para instalação de tanques sépticos, o desempenho deve } \\
\text { ser acima do padrão local de qualidade da água }\end{array}$ & 2 & 1 & 0 \\
\hline $\begin{array}{l}\text { 6) Uso de sistemas de reúso da água (redução do volume de } \\
\text { esgoto reduz a carga de tratamento de esgoto) }\end{array}$ & 2 & 1 & 0 \\
\hline 7) Outro & 2 & 1 & 0 \\
\hline
\end{tabular}

Fonte: Adaptado de JSCB (2003). 
São computados o número máximo de créditos que podem ser alcançados e o número de créditos efetivamente alcançados para realizar posteriormente a seguinte divisão:

$$
\text { Taxa }=\frac{\text { Créditos alcançados }}{\text { Número máximo de créditos possível }}
$$

A partir dessa taxa, a subcategoria Carga na infra-estrutura local pode ser classificada em um dos níveis a seguir:

1 - maior ou igual a 0 e menor que 0,2 ;

2 - maior ou igual a 0,2 e menor que 0,4 ;

3 - maior ou igual a 0,4 e menor que 0,6 ;

4 - maior ou igual a 0,6 e menor que $0,8 \mathrm{e}$

5 - maior ou igual a 0,8 e menor que 1,0 .

O CASBEE cita ainda algumas recomendações, como tipos de dispositivos facilitadores de percolação da água, algumas restrições quanto à carga de drenagem pluvial e quanto à carga no sistema de tratamento de esgoto sanitário. O método recomenda também a utilização desta água servida, inclusive apresentando uma tabela com alguns parâmetros de qualidade da água a serem alcançados de acordo com o uso a que essa água se destinará. 


\subsection{COMPARAÇÃO ENTRE OS CRITÉRIOS DE AVALIAÇÃO DOS SISTEMAS PREDIAIS HIDRÁULICOS E SANITÁRIOS E DO USO DA ÁGUA DOS SISTEMAS DE AVALIAÇÃO DE SUSTENTABILIDADE DE EDIFÍCIOS DE ESCRITÓRIOS}

Cada sistema de avaliação de sustentabilidade de edifícios propõe uma maneira diferente de avaliar a sustentabilidade ambiental dos sistemas prediais hidráulicos e sanitários e do uso da água em edifícios de escritórios. Com o objetivo de agrupar critérios com pretensões semelhantes e comparar os diferentes requisitos propostos em cada método, os diferentes critérios de avaliação são apresentados em uma tabela comparativa na seqüência. Assim, foi considerada a divisão dos critérios nas seguintes categorias de desempenho:

- confiabilidade, qualidade e manutenabilidade dos sistemas prediais hidráulicos e sanitários;

- saúde e qualidade sanitária da água;

- uso racional da água;

- carga na infra-estrutura local (drenagem pluvial);

- carga na infra-estrutura local (tratamento de esgotos);

- interferência do edifício em aqüíferos subterrâneos, áreas inundadas e cursos d'água;

- materiais componentes dos sistemas prediais hidráulicos e sanitários;

- reúso da água;

- aproveitamento de água pluvial.

A tabela 2.5 aponta os critérios de avaliação referentes aos sistemas prediais hidráulicos e sanitários e ao uso da água propostos pelos diferentes métodos de avaliação de 
sustentabilidade ambiental de edifícios de escritórios, agrupados nas categorias de desempenho anteriormente propostas.

Tabela 2.5 - Avaliação comparativa entre os critérios referentes aos sistemas prediais hidráulicos e sanitários e ao uso da água para cada sistema de avaliação de sustentabilidade ambiental

\begin{tabular}{|c|l|c|}
\hline \multicolumn{3}{|c|}{ Tema abordado relacionado à avaliação dos sistemas prediais hidráulicos e sanitários e } \\
do uso da água
\end{tabular}


continuação

\section{Saúde e qualidade sanitária da água}

\begin{tabular}{|c|c|c|}
\hline $\begin{array}{l}\text { Sistema } \\
\text { de } \\
\text { avaliação }\end{array}$ & Parâmetros avaliados & $\begin{array}{l}\text { Subitem } \\
\text { do } \\
\text { capítulo } 2\end{array}$ \\
\hline BREEAM & $\begin{array}{l}\text { Sistemas de aquecimento de água projetados para minimizar o } \\
\text { risco de contaminação por legionella Pneumophila ou ações que } \\
\text { minimizem este risco. }\end{array}$ & $2.2 \mathrm{~B}$ \\
\hline GBTool & Não há. & - \\
\hline LEED & Não há. & - \\
\hline \multirow{3}{*}{ CSTB } & $\begin{array}{l}\text { Separação total dos sistemas para que não ocorram conexões } \\
\text { cruzadas. }\end{array}$ & $2.5 \mathrm{~F}$ \\
\hline & $\begin{array}{l}\text { Controle da temperatura nos sistemas prediais hidráulicos para } \\
\text { minimizar riscos relacionados a legionella Pneumophila e a } \\
\text { acidentes com queimaduras. }\end{array}$ & $2.5 \mathrm{~F}$ \\
\hline & $\begin{array}{l}\text { Garantia de higiene dos sistemas prediais hidráulicos através de } \\
\text { tratamentos anti corrosão e anti incrustação. }\end{array}$ & $2.5 \mathrm{~F}$ \\
\hline CASBEE & Não há. & - \\
\hline \multicolumn{3}{|c|}{ Uso Racional da Água } \\
\hline $\begin{array}{l}\text { Sistema } \\
\text { de } \\
\text { avaliação }\end{array}$ & Parâmetros avaliados & $\begin{array}{l}\text { Subitem } \\
\text { do } \\
\text { capítulo } 2\end{array}$ \\
\hline \multirow{4}{*}{ BREEAM } & $\begin{array}{l}\text { Consumo: a pontuação obtida neste item varia de acordo com o } \\
\text { consumo anual previsto para o edifício. Maior valor aceitável para } \\
\text { o consumo de água: } 3,85 \mathrm{~m}^{3} / \text { pessoa/ano. }\end{array}$ & $2.2 \mathrm{C}$ \\
\hline & $\begin{array}{l}\text { Medição e monitoramento: medidores de água para todo o } \\
\text { suprimento do edifício. }\end{array}$ & $2.2 \mathrm{C}$ \\
\hline & $\begin{array}{l}\text { Deteç̧ão de vazamentos: sistema de detecção de vazamentos } \\
\text { cobrindo todos os principais pontos. }\end{array}$ & $2.2 \mathrm{C}$ \\
\hline & $\begin{array}{l}\text { Equipamentos economizadores: detector de presença em todos } \\
\text { os mictórios e bacias sanitárias. }\end{array}$ & $2.2 \mathrm{C}$ \\
\hline \multirow{2}{*}{ GBTool } & $\begin{array}{l}\text { Consumo: avalia o volume anual de água potável a ser utilizado } \\
\text { por pessoa }\left(\mathrm{m}^{3} / \text { pessoa/ano), descontando o volume proveniente de }\right. \\
\text { prática de reúso de água e de aproveitamento de água pluvial. }\end{array}$ & $2.3 \mathrm{~A}$ \\
\hline & $\begin{array}{l}\text { Medição e monitoramento: mecanismos para detecção de } \\
\text { vazamentos e procedimentos para resolver estes vazamentos. }\end{array}$ & $2.3 \mathrm{C}$ \\
\hline
\end{tabular}


continuação

\begin{tabular}{|c|c|c|}
\hline $\begin{array}{l}\text { Sistema } \\
\text { de } \\
\text { avaliação }\end{array}$ & Parâmetros avaliados & $\begin{array}{l}\text { Subitem } \\
\text { do } \\
\text { capítulo } 2\end{array}$ \\
\hline \multirow[t]{3}{*}{ LEED } & $\begin{array}{l}\text { Medição e monitoramento: previsão de equipamentos de } \\
\text { medição de água (sistemas prediais hidráulicos e de irrigação } \\
\text { paisagística), além de um plano de medição e verificação } \\
\text { (monitoramento dos dados). }\end{array}$ & $2.4 \mathrm{C}$ \\
\hline & $\begin{array}{l}\text { Equipamentos economizadores: emprego de estratégias que } \\
\text { reduzirão em pelo menos } 20 \% \text { o uso de água quando comparado } \\
\text { ao padrão calculado para o edifício, através do uso de dispositivos } \\
\text { de alta eficiência, além da prática de reúso de água e de } \\
\text { aproveitamento de água pluvial para fins não potáveis. }\end{array}$ & $2.4 \mathrm{~B}$ \\
\hline & $\begin{array}{l}\text { Limitação (em até } 50 \% \text { ) ou eliminação do uso de água potável } \\
\text { para irrigação paisagística através da utilização de tecnologia de } \\
\text { alta eficiência. }\end{array}$ & $2.4 \mathrm{~B}$ \\
\hline \multirow{4}{*}{ CSTB } & $\begin{array}{l}\text { Equipamentos economizadores: redução do consumo de água } \\
\text { potável através do uso de dispositivos economizadores de água e } \\
\text { através da redução de pressões de serviço. }\end{array}$ & $2.5 \mathrm{D}$ \\
\hline & $\begin{array}{l}\text { Equipamentos economizadores: limitação do consumo de água } \\
\text { no canteiro de obras através do uso de dispositivos para } \\
\text { economizar água potável. }\end{array}$ & $2.5 \mathrm{C}$ \\
\hline & $\begin{array}{l}\text { Conscientização dos usuários: redução do consumo de água } \\
\text { potável através da sensibilização dos usuários. }\end{array}$ & $2.5 \mathrm{D}$ \\
\hline & $\begin{array}{l}\text { Monitoramento: monitoramento do consumo de água a fim de } \\
\text { evitar desperdícios e vazamentos. }\end{array}$ & $2.5 \mathrm{D}$ \\
\hline CASBEE & $\begin{array}{l}\text { Equipamentos economizadores: presença de dispositivos } \\
\text { economizadores de água. }\end{array}$ & 2.6 A.1 \\
\hline \multicolumn{3}{|c|}{ Carga na infra-estrutura local (drenagem pluvial) } \\
\hline $\begin{array}{l}\text { Sistema } \\
\text { de } \\
\text { avaliação }\end{array}$ & Parâmetros avaliados & $\begin{array}{l}\text { Subitem } \\
\text { do } \\
\text { capítulo } 2 \\
\end{array}$ \\
\hline BREEAM & $\begin{array}{l}\text { Atenuar o escoamento superficial em, no mínimo, } 50 \% \text { no período } \\
\text { de pico, tanto para descarte em cursos naturais de água, como para } \\
\text { descarte nos sistemas municipais de drenagem pluvial. }\end{array}$ & $2.2 \mathrm{D}$ \\
\hline GBTool & $\begin{array}{l}\text { Disposição de água da chuva no terreno de modo a evitar carga } \\
\text { sobre a infra-estrutura local nos períodos de pico e impactos no } \\
\text { ecossistema local, como erosão de cursos naturais de água e } \\
\text { transbordamento de estações de tratamento. }\end{array}$ & $2.3 \mathrm{~B}$ \\
\hline
\end{tabular}


continuação

\begin{tabular}{|c|c|c|}
\hline $\begin{array}{l}\text { Sistema } \\
\text { de } \\
\text { avaliação }\end{array}$ & Parâmetros avaliados & $\begin{array}{l}\text { Subitem } \\
\text { do } \\
\text { capítulo } 2\end{array}$ \\
\hline \multirow[t]{2}{*}{ LEED } & $\begin{array}{l}\text { Redução de impactos negativos na qualidade da água através da } \\
\text { prevenção de sedimentação no sistema de drenagem e em córregos } \\
\text { receptores. }\end{array}$ & $2.4 \mathrm{~A}$ \\
\hline & $\begin{array}{l}\text { Limitação da destruição e poluição de fluxos naturais de água } \\
\text { através da administração do escoamento superficial. }\end{array}$ & $2.4 \mathrm{~A}$ \\
\hline \multirow{4}{*}{ CSTB } & $\begin{array}{l}\text { Otimização da retenção e infiltração da água da chuva, além da } \\
\text { recuperação da água de escoamento superficial poluída e } \\
\text { tratamento anterior ao despejo, em função da sua natureza. }\end{array}$ & $2.5 \mathrm{~A}$ \\
\hline & Gestão de águas pluviais através da retenção no terreno. & $2.5 \mathrm{D}$ \\
\hline & $\begin{array}{l}\text { Gestão de águas pluviais através da infiltração no terreno. } \\
\text { Coeficiente máximo de impermeabilização do solo: } 80 \% \text {, exceto } \\
\text { para áreas fortemente urbanizadas. }\end{array}$ & $2.5 \mathrm{D}$ \\
\hline & $\begin{array}{l}\text { Gestão das águas superficiais poluídas: disposições tomadas para } \\
\text { recuperar águas superficiais potencialmente poluídas e do } \\
\text { tratamento em função de sua natureza antes do descarte. }\end{array}$ & $2.5 \mathrm{D}$ \\
\hline CASBEE & $\begin{array}{l}\text { Redução das cargas de drenagem pluvial através de medidas que } \\
\text { garantam a percolação da água pluvial no solo e/ou a detenção } \\
\text { temporária. }\end{array}$ & 2.6 A. 2 \\
\hline \multicolumn{3}{|c|}{ Carga na infra-estrutura local (tratamento de esgoto) } \\
\hline $\begin{array}{l}\text { Sistema } \\
\text { de } \\
\text { avaliação }\end{array}$ & Parâmetros avaliados & $\begin{array}{l}\text { Subitem } \\
\text { do } \\
\text { capítulo } 2\end{array}$ \\
\hline BREEAM & Previsão de sistemas de tratamento de efluentes no local. & $2.2 \mathrm{D}$ \\
\hline GBTool & Não há, porém premia o reúso de água no local. & - \\
\hline LEED & $\begin{array}{l}\text { Inovações tecnológicas para as águas servidas: tratamento de } \\
100 \% \text { do esgoto no local (alcançando um padrão de tratamento } \\
\text { terciário). }\end{array}$ & $2.4 \mathrm{~B}$ \\
\hline CSTB & Coerência com as políticas ambientais de saneamento. & $2.5 \mathrm{~A}$ \\
\hline CASBEE & $\begin{array}{l}\text { Observação obrigatória de padrões de qualidade da água } \\
\text { descartada observando leis locais, quando o descarte é em rede } \\
\text { pública. Para instalação de tanques sépticos, o desempenho deve } \\
\text { ser acima do padrão local de qualidade da água. }\end{array}$ & 2.6 A. 2 \\
\hline
\end{tabular}


continuação

\begin{tabular}{|c|c|c|}
\hline \multicolumn{3}{|c|}{ Interferência do edifício em aqüíferos subterrâneos, áreas inundadas e cursos d'água } \\
\hline $\begin{array}{l}\text { Sistema } \\
\text { de } \\
\text { avaliação }\end{array}$ & Parâmetros avaliados & $\begin{array}{l}\text { Subitem } \\
\text { do } \\
\text { capítulo } 2\end{array}$ \\
\hline BREEAM & $\begin{array}{l}\text { Minimização de riscos de poluição de águas subterrâneas, cursos } \\
\text { d'água e de sistemas municipais. }\end{array}$ & $2.2 \mathrm{~A}$ \\
\hline GBTool & $\begin{array}{l}\text { Medidas apropriadas para manutenção das características de lagos } \\
\text { e aqüíferos. }\end{array}$ & $2.3 \mathrm{~B}$ \\
\hline LEED & $\begin{array}{l}\text { Localização: os edifícios devem estar distantes, no mínimo, } 30,48 \\
\text { metros de qualquer fonte de água, incluindo áreas inundadas, } \\
\text { como pântanos. }\end{array}$ & $2.4 \mathrm{~A}$ \\
\hline CSTB & $\begin{array}{l}\text { Poluição: ações visando a limitação da poluição da água no } \\
\text { canteiro de obras, como a utilização de produtos menos tóxicos, } \\
\text { identificação dos reservatórios de água, controle e coleta de } \\
\text { efluentes. }\end{array}$ & $2.5 \mathrm{C}$ \\
\hline CASBEE & Não há. & \\
\hline \multicolumn{3}{|c|}{ Materiais componentes dos sistemas prediais hidráulicos e sanitários } \\
\hline $\begin{array}{l}\text { Sistema } \\
\text { de } \\
\text { avaliação }\end{array}$ & Parâmetros avaliados & $\begin{array}{l}\text { Subitem } \\
\text { do } \\
\text { capítulo } 2\end{array}$ \\
\hline BREEAM & Não há. & - \\
\hline GBTool & Não há. & - \\
\hline LEED & Não há. & - \\
\hline \multirow{4}{*}{ CSTB } & $\begin{array}{l}\text { Escolha integrada dos produtos, sistemas e processos construtivos } \\
\text { de modo a limitar os impactos ambientais da obra. Devem ser } \\
\text { analisados a durabilidade, adaptabilidade, acessibilidade, impactos } \\
\text { ambientais da obra e impactos sanitários dos produtos e deve ser } \\
\text { realizado um cálculo da carga ambiental sobre recursos. }\end{array}$ & $2.5 \mathrm{~B}$ \\
\hline & $\begin{array}{l}\text { Obtenção de uma autorização de conformidade sanitária para } \\
\text { todos os materiais componentes dos sistemas prediais hidráulicos } \\
\text { e sanitários. }\end{array}$ & $2.5 \mathrm{~F}$ \\
\hline & $\begin{array}{l}\text { Os materiais componentes dos sistemas prediais hidráulicos não } \\
\text { devem interferir nas condições físico-químicas da água a ser } \\
\text { consumida. }\end{array}$ & $2.5 \mathrm{~F}$ \\
\hline & $\begin{array}{l}\text { Projeto com especificação de materiais que respeite as normas } \\
\text { pertinentes. }\end{array}$ & $2.5 \mathrm{~F}$ \\
\hline CASBEE & $\begin{array}{l}\text { O intervalo de renovação (reforma ou substituição) para } \\
\text { equipamentos e serviços necessários ao funcionamento de } \\
\text { edifícios de escritório (como boilers, chillers, reservatórios de } \\
\text { água, sistemas elevatórios de água) deve ser de, no mínimo, } 7 \\
\text { anos. }\end{array}$ & $2.6 \mathrm{~A}$ \\
\hline
\end{tabular}


continuação

\begin{tabular}{|c|c|c|}
\hline \multicolumn{3}{|c|}{ Reúso da água } \\
\hline $\begin{array}{l}\text { Sistema } \\
\text { de } \\
\text { avaliação }\end{array}$ & Parâmetros avaliados & $\begin{array}{l}\text { Subitem } \\
\text { do } \\
\text { capítulo } 2\end{array}$ \\
\hline BREEAM & Não há. & - \\
\hline GBTool & $\begin{array}{l}\text { Reúso de água no local para diminuição do volume anual de } \\
\text { esgoto (águas cinza) encaminhado ao sistema de tratamento de } \\
\text { esgoto. }\end{array}$ & $2.3 \mathrm{~B}$ \\
\hline LEED & $\begin{array}{l}\text { Limitação ou eliminação do uso de água potável para irrigação } \\
\text { paisagística através do reúso da água. }\end{array}$ & $2.4 \mathrm{~B}$ \\
\hline CSTB & $\begin{array}{l}\text { Redução do consumo de água potável através da utilização de } \\
\text { água não potável para usos que não requerem água com tal } \\
\text { qualidade. }\end{array}$ & $2.5 \mathrm{D}$ \\
\hline & $\begin{array}{l}\text { Redução da carga na infra-estrutura local de tratamento de esgoto } \\
\text { através de sistemas de reúso da água. }\end{array}$ & $2.6 \mathrm{~A}$ \\
\hline CASBEE & $\begin{array}{l}\text { Contenção da formação de "ilhas de calor" com a previsão de } \\
\text { espaços verdes e de um corpo d'água no terreno. Uma das } \\
\text { recomendações é o emprego de irrigação de áreas verdes } \\
\text { utilizando água pluvial e de esgoto (reúso da água). }\end{array}$ & 2.6 B.1 \\
\hline \multicolumn{3}{|c|}{ Aproveitamento de água pluvial } \\
\hline $\begin{array}{c}\text { Sistema } \\
\text { de } \\
\text { avaliação }\end{array}$ & Parâmetros avaliados & $\begin{array}{l}\text { Subitem } \\
\text { do } \\
\text { capítulo } 2 \\
\end{array}$ \\
\hline BREEAM & Não há. & - \\
\hline GBTool & Não há. & - \\
\hline \multirow[t]{2}{*}{ LEED } & $\begin{array}{l}\text { Gerenciamento de águas pluviais: previsão de um sistema de } \\
\text { tratamento. }\end{array}$ & $2.4 \mathrm{~A}$ \\
\hline & $\begin{array}{l}\text { Limitação ou eliminação do uso de água potável para irrigação } \\
\text { paisagística com a utilização de água pluvial. }\end{array}$ & $2.4 \mathrm{~B}$ \\
\hline CSTB & $\begin{array}{l}\text { Redução do consumo de água potável através do uso de água de } \\
\text { qualidade inferior quando o uso assim permitir: aproveitamento de } \\
\text { água pluvial. }\end{array}$ & $2.5 \mathrm{D}$ \\
\hline \multirow[b]{2}{*}{ CASBEE } & $\begin{array}{l}\text { Parcela de utilização de água pluvial de, no mínimo, } 20 \% \text {. Esta } \\
\text { parcela é o quociente entre o volume previsto de uso de água } \\
\text { pluvial e o volume total previsto de uso de água para fíns } \\
\text { benéficos no edifício. }\end{array}$ & $2.6 \mathrm{~A}$ \\
\hline & $\begin{array}{l}\text { Contenção da formação de "ilhas de calor", citando a prática da } \\
\text { irrigação dos espaços verdes com água pluvial. }\end{array}$ & $2.6 \mathrm{~B}$ \\
\hline
\end{tabular}




\subsection{CONSIDERAÇÕES SOBRE OS CRITÉRIOS REFERENTES AOS SISTEMAS PREDIAIS HIDRÁULICOS E SANITÁRIOS CONTEMPLADOS NOS MÉTODOS DE AVALIAÇÃO PESQUISADOS}

Dependendo de fatores tais como o contexto local, as prioridades são diferentes para cada um dos sistemas de avaliação e, conseqüentemente, algumas categorias de desempenho são mais ou menos enfatizadas e os parâmetros de avaliação, diferentes. A partir da análise da tabela comparativa dos diferentes requisitos de avaliação, os diferentes critérios de avaliação dos sistemas prediais hidráulicos e do uso da água em edifícios de escritórios foram agrupados tendo como base as categorias propostas anteriormente.

Como os critérios propostos pelos sistemas de avaliação de sustentabilidade ambiental possuem organização e nomenclatura pertinentes a cada um dos métodos, foi elaborada uma lista única que engloba todos os principais critérios estudados para os diferentes sistemas, a qual será utilizada para subsidiar as propostas efetuadas no capítulo seguinte.

A) Confiabilidade, qualidade e manutenabilidade dos sistemas prediais hidráulicos e sanitários

Nesse item são contemplados os seguintes critérios:

- disponibilização de guia informativo para o administrador do edifício, com dados sobre os sistemas prediais hidráulicos e sanitários;

- provisão de projetos "como construído" dos sistemas prediais hidráulicos e sanitários;

- treinamento e conscientização dos usuários;

- uso de diferentes cores para identificação dos sistemas prediais que transportam água não potável;

- manutenabilidade: previsão de dispositivos de fechamento dos sistemas prediais 
de suprimento de água de maneira setorizada e de acesso para manutenção dos sistemas prediais hidráulicos e sanitários;

- controle da manutenção da temperatura da água no sistema predial de água quente: previsão de sistema de controle e gestão e

- confiabilidade: continuidade de abastecimento.

B) Saúde e qualidade sanitária da água

Os seguintes critérios são contemplados nessa categoria:

- tratamentos anti corrosão e anti incrustação nos sistemas prediais de abastecimento de água potável;

- separação total dos sistemas e

- minimização dos riscos de contaminação por legionella Pneumophila.

C) Uso racional da água

Os critérios contemplados nessa categoria são:

- utilização de equipamentos economizadores;

- medição e monitoramento e

- conscientização dos usuários.

D) Carga na infra-estrutura local (drenagem pluvial)

Os seguintes critérios são contemplados nesse item:

- disposição da água da chuva no terreno: detenção temporária;

- disposição da água da chuva no terreno: infiltração no solo e

- recuperação e tratamento de água de escoamento superficial poluída. 
E) Carga na infra-estrutura local (tratamento de esgoto)

Essa categoria contempla apenas um critério:

- observação do padrão de qualidade exigido pela legislação local para os efluentes.

F) Interferência do edifício em aqüíferos subterrâneos, áreas inundadas e cursos d'água

Nesse item são contemplados os seguintes critérios:

- manutenção das características da água em aqüíferos subterrâneos, áreas inundadas e cursos d'água localizados no terreno e

- localização do terreno: distância mínima de corpos d'água.

G) Materiais componentes dos sistemas prediais hidráulicos e sanitários

Os seguintes critérios são contemplados nesse item:

- escolha integrada dos produtos, sistemas e processos construtivos de modo a limitar os impactos ambientais e - adequação à legislação e às normas técnicas locais.

H) Reúso da água

Esse item apresenta apenas um critério:

- utilização de águas servidas para usos benéficos no edifício.

I) Aproveitamento de água pluvial

Apenas um critério consta nessa categoria:

- utilização de águas pluviais para usos benéficos no edifício. 
O presente capítulo abordou a maneira pela qual os métodos de avaliação analisam os sistemas prediais hidráulicos e sanitários e o uso da água em edifícios de escritórios, compilando os critérios em categorias de desempenho. A partir desta divisão, com a verificação dos pontos pertinentes contemplados na documentação técnica consultada, pretende-se chegar também a outros critérios que venham a integrar uma lista única, proposta no próximo capítulo do presente trabalho. 


\section{CRITÉRIOS DE AVALIAÇÃO DE SUSTENTABILIDADE AMBIENTAL DOS SISTEMAS PREDIAIS HIDRÁULICOS E SANITÁRIOS E DO USO DA ÁGUA EM EDIFÍCIOS DE ESCRITÓRIOS}

O presente capítulo apresenta a verificação de pontos pertinentes aos critérios analisados pelos métodos de avaliação estudados, além de outros critérios contemplados na documentação técnica consultada. É importante porém, lembrar que, para pôr em prática cada um destes critérios, há cargas ambientais que precisam ser quantificadas para que se chegue ao impacto de cada ação. $\mathrm{O}$ consumo de recursos, o $\mathrm{CO}_{2}$ incorporado e a poluição gerada pela fabricação de um determinado componente ou sistema precisam ser levados em conta, por exemplo. O consumo de recursos para operação e manutenção também, assim como seu destino final.

Para aproximar o presente trabalho do conceito de eficiência ambiental do edifício, a definição do CASBEE pode ser utilizada (figura 5).

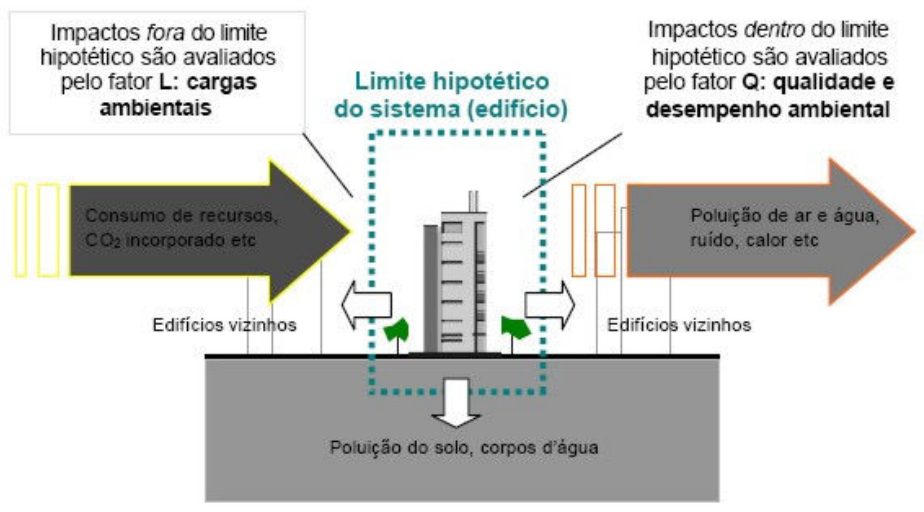

Figura 5 - Estrutura conceitual do CASBEE

Fonte: SILVA (2003) 
Segundo Silva (2003), o fator qualidade ambiental avaliado pelo CASBEE se refere à qualidade e ao desempenho ambiental do edifício, dentro do espaço hipotético, que é o ambiente como propriedade privada. As cargas ambientais são os impactos negativos que se estendem para fora deste espaço hipotético. A avaliação de critérios se dá através da medição de esforços para redução das cargas ambientais. São avaliados pelo CASBEE a utilização de energia, a eficiência dos sistemas, a utilização de água e de materiais (recursos, energia, $\mathrm{CO}_{2}$ incorporado), a poluição, a carga na infra-estrutura local, o acesso a iluminação, ventilação, o efeito "ilha de calor", etc.

Dentro do limite hipotético do terreno, os critérios propostos objetivam a utilização da água de modo a contribuir para sua conservação, mantidos o conforto e a saúde dos usuários. Fora do limite hipotético, os critérios propostos também contribuem para a conservação da água (que além de ser de interesse dos usuários do edifício, também é parte importante na análise de impactos no meio ambiente). Ainda fora do limite hipotético, os critérios propostos procuram contribuir para a redução de carga de drenagem pluvial, de tratamento de esgotos e de distribuição de água potável, além da redução da poluição de corpos d'água.

É importante, portanto, ressaltar que os impactos ambientais de cada especificação, quando do projeto e execução de um edifício, precisam ser analisados para que a esperada sustentabilidade ambiental seja, de fato, alcançada. 


\subsection{CRITÉRIOS PROPOSTOS PELOS SISTEMAS DE AVALIAÇÃO PESQUISADOS CONTEMPLADOS NA DOCUMENTAÇÃO TÉCNICA E NA NORMALIZAÇÃO BRASILEIRA}

3.1.1 Confiabilidade, qualidade e manutenabilidade dos sistemas prediais hidráulicos e sanitários

A) Disponibilização de guia informativo para o administrador do edifício, com dados sobre os sistemas prediais hidráulicos e sanitários

O guia deve conter informações sobre a manutenção preventiva dos sistemas prediais de água fria, água quente, esgoto sanitário, águas pluviais, além de sistemas de aproveitamento de águas pluviais e de reúso da água, quando houver. O guia também deve conter informações sobre conservação da água, além de aspectos de segurança, saúde e qualidade da água (como periodicidade de limpeza de reservatórios, manutenção da potabilidade da água, laudos necessários). Segundo Prado et al. (2000), deve ser disponibilizado um manual que estabeleça os procedimentos de uso e manutenção (preventiva, corretiva ou de urgência) compatíveis com os sistemas prediais hidráulicos e sanitários, para os usuários dos edifícios.

ABNT, através do Comitê Brasileiro de Construção Civil, desenvolveu o Projeto "Desempenho de edifícios habitacionais até cinco pavimentos" (ABNT, 2004a), dividido em seis partes. A sexta parte trata dos sistemas hidráulicos e sanitários, propondo que seja desenvolvido um manual que especifique todas as condições de uso, operação e manutenção dos sistemas prediais hidráulicos e sanitários e de seus componentes. Esse manual deve conter recomendações sobre a utilização dos componentes dos sistemas prediais hidráulicos e sanitários, processos de desobstrução, limpeza e conservação dos componentes, periodicidade 
de inspeções e manutenções dos sistemas, além de técnicas, processos e equipamentos necessários para manutenção. Convém lembrar que tal projeto foi idealizado para a verificação de desempenho de edificações habitacionais para população de baixa renda, por isso a aderência dos requisitos de desempenho para edifícios de escritórios deve ser verificada.

A NBR 14037 (ABNT, 1998) dá recomendações quanto à elaboração e apresentação do manual de operação, uso e manutenção de edificações, estabelecendo o conteúdo a ser incluído. Os objetivos do manual, segundo a referida norma, são:

- informar aos usuários as características técnicas da edificação;

- descrever procedimentos recomendáveis;

- orientar os usuários para a realização de atividades de manutenção;

- prevenir falhas e acidentes decorrentes de uso inadequado e

- contribuir para aumento da durabilidade da edificação.

A referida norma recomenda que a redação do manual seja simples e apresente informações de forma didática sobre operação, uso e manutenção do edifício, além de responsabilidades e garantias. O manual deve trazer também o conjunto completo de projetos e discriminações técnicas atualizadas em relação ao que foi realmente construído (ABNT, 1998).

Segundo Amorim (1997), o guia informativo deve conter informações técnicas sobre materiais, componentes, equipamentos e subsistemas dos sistemas prediais hidráulicos e sanitários. O autor afirma que o manual deve conter orientações a serem seguidas para que haja bom funcionamento de reservatórios, do sistema elevatório de água, de piscinas, do sistema de combate a incêndio, do sistema elevatório de esgoto e águas pluviais e de sistemas de aquecimento de água. Segundo Novaes (1996), o projeto “como construído" deve ser parte 
integrante do manual a ser disponibilizado aos usuários.

O impacto de redução de cargas ambientais deste critério se dá pela maior eficiência na operação dos sistemas prediais hidráulicos e sanitários, gerando como conseqüência uma redução na carga sobre a infra-estrutura de distribuição de água e coleta de esgotos sanitários. Outro ponto importante é a correta manutenção do sistema, que contribui para o aumento da vida útil de seus componentes, reduzindo assim, o tempo necessário para substituição de materiais.

B) Provisão de projetos “como construído" dos sistemas prediais hidráulicos e sanitários

Segundo pesquisa realizada por Amorim (1997), o projeto de acordo com o que foi construído ainda não é realidade plena no Brasil. A não disponibilização desse tipo de projeto aos usuários do edifício, por parte do empreendedor, gera problemas como a dificuldade de manutenção, gastos desnecessários e desconforto aos usuários (pela necessidade de interrupção de abastecimento para eventual necessidade de manutenção, por exemplo).

O referido autor afirma também que os projetistas e profissionais responsáveis pela execução da obra são os responsáveis pelo fornecimento das informações para a confecção do projeto “como construído". O processo de confecção envolve visitas do projetista ao canteiro de obras, discussão com os profissionais responsáveis pela execução quanto às soluções de eventuais problemas durante a execução e participação em reuniões técnicas para esclarecimento de dúvidas. O projeto "como construído" será útil não apenas aos profissionais durante a execução da obra, como também aos demais usuários, que estarão em contato com o edifício durante sua operação. A importância da disponibilização do projeto “como construído" também é citada por Arantes (2003), em sua proposta de modelo de avaliação de qualidade para projetos de sistemas prediais hidráulicos e sanitários.

Dessa maneira, a provisão do projeto "como construído" trará economia (por evitar 
incursões desnecessárias) e conforto (por tornar a manutenção mais rápida e eficiente) aos usuários do edifício. Segundo Novaes (1996), o projeto a ser arquivado e a ser entregue aos usuários "deve representar fielmente o objeto construído, com registros, no conjunto do projeto, de todas as alterações que por ventura tenham se verificado durante a execução". Segundo o autor, esta prática dará suporte às atividades de manutenção e servirá para identificação de causas de problemas que eventualmente surjam após a ocupação do edifício.

O impacto de redução de cargas ambientais se dá devido à possibilidade de corretas incursões de reforma ou substituição de componentes dos sistemas prediais hidráulicos e sanitários, havendo, como conseqüência, menor geração de resíduos.

C) Treinamento e conscientização dos usuários

O treinamento dos usuários para a operação dos sistemas prediais hidráulicos e sanitários trará segurança, na medida em que evitará acidentes e contaminações ocasionados pelo mau uso. Outro benefício do treinamento é o conforto dos usuários, já que o treinamento propicia a completa utilização das funções dos componentes dos sistemas prediais hidráulicos e sanitários. As campanhas de conscientização devem ser planejadas e têm o objetivo de incentivar o uso correto dos sistemas e de economizar água potável.

Silva (2003) também cita, na ferramenta proposta para avaliação de sustentabilidade ambiental de edifícios de escritórios no Brasil, ações de treinamento dos usuários responsáveis pela manutenção e operação do edifício.

O impacto de redução de cargas ambientais se dá através da economia de água, redução de carga no sistema público de distribuição de água e de coleta de esgotos, resultados esperados em campanhas de conscientização e treinamento.

D) Uso de diferentes cores para identificação dos sistemas prediais que transportam água não 
potável.

Os sistemas prediais que transportam água potável devem ser diferenciados dos sistemas que transportam água não-potável para evitar a utilização da água para finalidades que não as especificadas. A NBR 6493 (ABNT, 1998) fixa padrões para identificação de tubulações industriais através do emprego de diferentes cores. A norma recomenda que a tubulação que transporta água potável seja diferenciada de forma inconfundível de outros tipos de tubulação. A recomendação para adoção das cores é que a tubulação de combate a incêndio receba pintura vermelha; de água, verde; de ar comprimido, azul; eletrodutos, cinza escuro; etc.

Blum (2002) sugere que seja criado um padrão de identificação para os elementos do sistema de reúso de água, que pode ser através de cores, além da implantação de um canal de comunicação com os usuários a fim de esclarecer as restrições de utilização da água de reúso. Santos (2002c) cita a importância da padronização ao descrever o sistema de reúso de água do Projeto São Caetano, que utiliza água proveniente da Estação de Tratamento de Efluentes $\mathrm{ABC}$ para a rega de parques e lavação de ruas na cidade de São Caetano. Todo o sistema (equipamentos e tubulação) e os veículos utilizados no projeto para transporte de água não potável possuem a cor padrão púrpura, além de a tubulação ser rotulada com a frase "Água não potável - não beba”.

A NBR 13969 (ABNT, 1997) prevê a utilização de águas servidas e recomenda a clara identificação do sistema de reservação e de distribuição da água de reúso. Esta identificação deve ser realizada através do emprego de placas indicativas nos reservatórios, na tubulação e nas torneiras e do uso de cores distintas (em todo o sistema que transporta água de reúso) das cores empregadas no sistema que transporta água potável.

A contaminação da água traz impactos ambientais através do desperdício gerado ao inutilizar água com padrão de potabilidade, principalmente se houve necessidade de 
tratamento para que chegasse a tal padrão. O que ocorre é desperdício de água e possivelmente de energia (para tratamento, por exemplo).

E) Manutenabilidade: previsão de dispositivos de fechamento dos sistemas prediais de suprimento de água de maneira setorizada e de acesso para manutenção dos sistemas prediais hidráulicos e sanitários

Uma das exigências da NBR 5626 (ABNT, 1998) é que o projeto do sistema predial de água fria seja projetado de modo a possibilitar manutenção fácil e econômica. Ainda recomenda a utilização de registros de fechamento ou de outros dispositivos que cumpram a mesma função no barrilete, nas colunas de distribuição e nos ramais de distribuição de água. A previsão de acesso aos sistemas prediais hidráulicos e sanitários é imprescindível para evitar custos desnecessários quando da manutenção.

ABNT (2004a) cita a previsão da necessidade de manutenção preventiva e corretiva nos sistemas, propondo que os sistemas prediais de esgoto sanitário e de águas pluviais sejam inspecionáveis em qualquer parte, sem que haja necessidade de quebra ou desmonte de partes do sistema.

Dessa maneira, para que seja assegurada a facilidade de manutenção dos sistemas prediais hidráulicos e sanitários do edifício de escritórios, é necessária a previsão de dispositivos de fechamento dos sistemas prediais de suprimento de água de maneira setorizada, além da previsão de acesso para manutenção dos sistemas. Prado et al. (2000) recomendam que a localização dos reservatórios de água permita a limpeza e que a localização de todos os componentes dos sistemas prediais permita manutenção. Os autores afirmam ainda, sobre os sistemas prediais hidráulicos e sanitários, que a manutenção compreende um conjunto de ações necessárias para garantia do controle do desempenho no nível pré-estabelecido para os sistemas. A manutenção deve constituir um programa contínuo 
de atividades capazes de evitar e corrigir deficiências no sistema, de modo a assegurar seu correto funcionamento.

Silva (2003) propõe, na ferramenta de avaliação de sustentabilidade ambiental de edifícios de escritórios brasileiros, o critério planejamento da operação e manutenção do edifício, onde são analisadas as facilidades previstas para as atividades de manutenção. A mesma ferramenta analisa o desempenho dos sistemas prediais verificando a acessibilidade aos componentes dos sistemas para manutenção e substituição. Santos (2002a) e Rosrud apud Farina (2003) também citam a importância da consideração do fator manutenabilidade quando da análise de desempenho de sistemas prediais hidráulicos e sanitários.

Possibilitando e facilitando a correta manutenção dos sistemas prediais hidráulicos e sanitários, a redução de cargas ambientais se dá por evitar o desperdício de água (facilitando reparos de vazamentos, por exemplo); e por evitar também a geração de resíduos, resultado da necessidade de criação de acessos não previstos.

F) Controle da manutenção da temperatura da água no sistema predial de água quente: previsão de sistema de controle e gestão

O controle da temperatura do reservatório de água quente pode ser realizado por equipamentos controladores de temperatura, com saída de dados digital, que permitem ao usuário escolher a temperatura de utilização da água. A NBR 7198 (ABNT, 1993) apenas exige que os aquecedores sejam dotados de dispositivo automático de controle da temperatura máxima admissível da água, não citando nenhum tipo de sistema de controle e gestão do sistema predial de água quente. A mesma Norma Técnica fixa a temperatura máxima da água nos sistemas prediais de água quente em $70^{\circ} \mathrm{C}$.

Em ABNT (2004a), observa-se o risco de queimaduras ao propor critérios de desempenho para os sistemas prediais de água quente. O projeto propõe que os aparelhos 
elétricos de acumulação sejam providos de dispositivos de alívio para o caso de sobrepressão e de dispositivo de segurança para o caso de superaquecimento. O projeto também propõe a temperatura máxima de saída da água aquecida, por equipamento de aquecimento. Estes cuidados no projeto e especificação dos componentes do sistema predial de água quente objetivam, além do conforto para o usuário, assegurar saúde e segurança.

Para esse critério, o impacto de redução de cargas ambientais se dá pela economia de energia através da utilização de um sistema de controle e gestão do sistema de aquecimento de água.

G) Confiabilidade: continuidade de abastecimento

Nesse critério, sugerido apenas pelo CASBEE, é considerada a possibilidade de funcionamento dos sistemas prediais hidráulicos e sanitários na ocorrência de desastres naturais. Visa, assim, a garantia de abastecimento de água e de destino do esgoto sanitário gerado, no caso da ocorrência de um desastre natural.

No Brasil, a continuidade do fornecimento de água é um dos requisitos de desempenho propostos pela $\mathrm{ABNT}$ (2004a), ainda que não relacionado à ocorrência de desastres naturais. A proposta é que haja a garantia de abastecimento, mesmo quando o fornecimento público seja passível de descontinuidade. Dessa maneira, o projeto dos sistemas prediais de suprimento de água deve prever reservatórios compatíveis com o número de usuários do edifício e com o tempo de interrupção do fornecimento. O critério de avaliação é a análise do dimensionamento do volume de reservação de água, que deve ser calculado de modo a suprir as necessidades do edifício por, pelo menos, um dia.

Para esse critério, o impacto de redução de cargas ambientais está na eficiência dos sistemas prediais do edifício. 


\subsubsection{Saúde e qualidade sanitária da água}

A) Preservação da potabilidade da água: tratamento contra formação de incrustações e de corrosão nos sistemas prediais de abastecimento de água potável

Esse critério visa assegurar a higiene dos sistemas prediais hidráulicos que transportam água potável, preservando a saúde dos usuários. A incrustação, segundo Melo (2005), tende a se formar com a elevação do $\mathrm{pH}$ da água e a dureza da água resulta principalmente na presença de íons de sais, como o cálcio. Castro apud Hoffmann (2004) descreve que a dureza elevada tende a formar incrustações de carbonatos, principalmente para água quente. Hoffmann (2004) lembra, porém, que águas com pouca dureza podem se tornar corrosivas.

Rosrud apud Farina (2003) estuda os requisitos de desempenho para o sistema predial de suprimento de água fria e estabelece a resistência à corrosão como um dos requisitos ao considerar as ações externas, do ambiente, sobre o sistema. Segundo Correc, Derrien e Diab (2005), a corrosão pode modificar os parâmetros de qualidade da água e favorecer o desenvolvimento de bactérias.

A preocupação com a resistência à corrosão e com a formação de incrustações nos sistemas prediais de abastecimento de água potável é imprescindível para garantia da saúde dos usuários e para a preservação da potabilidade da água, segundo os referido autores. $\mathrm{O}$ impacto de redução de cargas ambientais desse critério se dá pela maior eficiência na operação dos sistemas, preservando a qualidade da água, reduzindo a carga sobre a infra-estrutura de coleta de esgotos sanitários e preservando os componentes dos sistemas prediais hidráulicos (reduzindo assim, o tempo necessário para substituição de materiais). 
B) Preservação da potabilidade da água: separação total dos sistemas

ABNT (2004a), no item "Saúde e higiene" propõe que haja separação física dos sistemas prediais hidráulicos de qualquer sistema que conduza "água não potável ou fluido de qualidade insatisfatória, desconhecida ou questionável”. Nesse mesmo item são recomendadas, para evitar a contaminação por agentes externos, as seguintes especificações no projeto de tubulações enterradas de água potável:

As tubulações enterradas devem distar horizontalmente no mínimo 3,0m de qualquer fonte potencialmente poluidora, tais como tubulações enterradas de esgoto, fossas sépticas, sumidouros, valas de infiltração, etc. Quando houver necessidade de cruzamento de tubulações enterradas de água e esgoto, o fundo da tubulação de água deve ficar no mínimo $0,30 \mathrm{~m}$ acima da geratriz superior da tubulação de esgoto.

O projeto e a execução dos sistemas prediais hidráulicos devem ser realizados de modo a assegurar que não ocorram ligações cruzadas do sistema de esgotos sanitários ou de qualquer sistema que transporte água proveniente de fontes alternativas com os sistemas prediais que transportam água potável.

Para esse critério, devem ser levadas em consideração as cargas ambientais provenientes da contaminação da água e do desperdício gerado ao inutilizar água com padrão de potabilidade (principalmente se houve necessidade de tratamento para que esta chegasse a tal padrão).

C) Minimização dos riscos de contaminação por legionella Pneumophila

A contaminação nos sistemas prediais hidráulicos pode se dar através da reservação de água para beber, para banho, lavagem ou outros propósitos (VAN DER SCHEE, 2005). As ações para a minimização do risco de contaminação devem iniciar com o conhecimento e a verificação de todos os pontos de consumo em que possa haver a formação de aerossóis, além da separação total dos sistemas que conduzem água fria e água quente. A proposta do referido 
autor para garantir esta última ação é o emprego de válvulas de retenção que impeçam o retorno de água quente dos aquecedores para o sistema de água fria. A NBR 7198 (ABNT, 1993), no entanto, apenas permite o uso de válvula de retenção no ramal de alimentação de água fria do aquecedor, quando este ramal de alimentação de água por gravidade for protegido por respiro.

Os fatores de risco de contaminação por legionella Pneumophila, segundo Van der Schee (2005), são:

- temperatura de água entre $25^{\circ} \mathrm{C}$ e $50^{\circ} \mathrm{C}$;

- água estagnada;

- períodos longos sem a utilização do sistema e

- sedimentação e formação de biofilme.

Navarotto (2004) cita o risco de contaminação através de torres de resfriamento e dos sistemas de distribuição de água em edifícios, também associado a temperaturas entre $25^{\circ} \mathrm{C}$ e $50^{\circ} \mathrm{C}$. Van Wolferen (2001) apresenta os riscos de contaminação nos pontos de consumo associados ao desenvolvimento da bactéria em temperaturas entre $20^{\circ} \mathrm{C}$ e $50^{\circ} \mathrm{C}$ (figura 6).

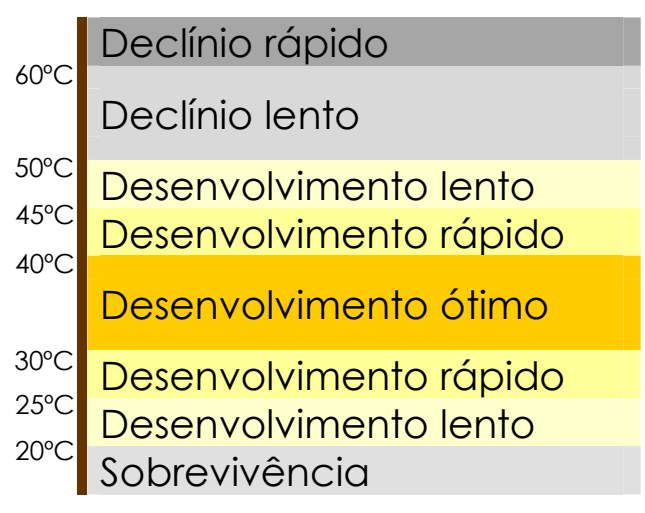

Figura 6 - Desenvolvimento e declínio da legionella de acordo com a temperatura da água Fonte: VAN WOLFEREN (2001). 
Van der Schee (2005) recomenda ainda que não haja trechos nos sistemas prediais hidráulicos que favoreçam a estagnação da água e que, se forem utilizados métodos de desinfecção, que a efetividade seja periodicamente verificada. Para esse critério, o impacto de redução de cargas ambientais está na eficiência dos sistemas prediais do edifício contribuindo para manutenção da saúde pública.

\subsubsection{Uso racional da água}

A) Utilização de equipamentos economizadores

Os sistemas prediais hidráulicos devem ser projetados de modo a minimizarem o consumo de água, reduzindo a demanda de água da rede pública de abastecimento e o volume de esgoto a ser tratado (ABNT, 2004a). Para isso, podem ser empregados equipamentos economizadores e dispositivos de alta eficiência. A referida norma sugere o emprego de bacias sanitárias de volume de descarga reduzido, o emprego de torneiras de lavatório e pia dotadas de arejadores e a limitação da vazão em chuveiros a um valor máximo igual a 9 litros/minuto. FGBC (2004) sugere a utilização de composting toilets, mictórios sem água e de dispositivos dotados de sensores de presença. A Agenda 21 on Sustainable Construction (1999) também sugere o emprego de composting toilets, além de bacias sanitárias com sistema dual flush, e de chuveiros com restritores de vazão.

Silva (2003), quando da avaliação de sustentabilidade ambiental de edifícios de escritório, analisa as medidas incorporadas no projeto que objetivam a economia de água e, entre elas, a previsão de dispositivos eficientes e economizadores. Alguns equipamentos economizadores de água que podem ser especificados no projeto dos sistemas prediais hidráulicos de edifícios de escritórios são (IOSHIMOTO, OLIVEIRA, GONÇALVES, 2004): - torneira com funcionamento hidromecânico; 
- torneira com funcionamento por sensor de presença;

- torneira com acionamento por válvula de pé;

- torneira com acionamento por pedal;

- arejadores;

- torneira de comando restrito;

- mictórios com acionamento hidromecânico;

- mictório com válvula de acionamento por sensor de presença;

- mictório com válvula de descarga temporizada;

- mictório sem água;

- bacias sanitárias com volume de descarga por acionamento igual a 6 litros;

- bacias sanitárias com válvula de acionamento por sensor de presença;

- bacias sanitárias com caixa acoplada e sistema dual flush e

- dispositivos restritores de vazão.

Shouler (2005) propõe a utilização de bacias sanitárias dual flush, controle de pressão em chuveiros, restritores de vazão e a rotulagem de produtos economizadores de água para promoção da sustentabilidade em edifícios. Asano (2005) afirma que a economia de água leva à redução do consumo de energia e da geração de dióxido de carbono, utilizados para tratamento de água que abastece o edifício e para posterior tratamento de esgotos gerados.

O impacto de redução de cargas ambientais desse critério se dá pela maior eficiência dos sistemas prediais hidráulicos, que leva a uma redução na carga sobre a infra-estrutura de distribuição de água e coleta de esgotos sanitários. Isso também gera como conseqüência a utilização de menos energia e menor geração de $\mathrm{CO}_{2}$.

B) Medição e monitoramento 
Todos os sistemas de avaliação de sustentabilidade ambiental de edifícios de escritório analisados, com exceção do CASBEE, contemplam ações de gerenciamento do consumo de água. O objetivo é que se otimize o desempenho referente ao consumo de água através de medição, monitoramento, avaliação e correção de eventuais desperdícios e vazamentos. A medição setorizada ou individualizada já é, por si, uma ferramenta de incentivo à economia de água. Segundo Santos (2002a) e Yamada, Prado e Ioshimoto (2001), o pagamento, em função do consumo gerado pela medição individualizada ou setorizada, faz com que o usuário passe a ter maior consciência do uso da água.

As coletas de dados de consumo podem ser realizadas através de medição setorizada e telemedição ou mesmo através de instrumentos simples, como análise de contas de água e leituras in loco. Deve ser realizado um levantamento de dados (cadastramento de pontos, área atendida, número de usuários, além dos dados de consumo) que possibilitará a elaboração de indicadores de consumo. Dessa maneira, é possível estabelecer parâmetros de controle, como o consumo mensal, o consumo mensal per capita e consumo mensal por área (TAMAKI, 2003). Tais indicadores devem ser revisados periodicamente para detectar possíveis anomalias no consumo e posterior correção de vazamentos.

Assim como no critério anteriormente descrito, o impacto de redução de cargas ambientais se dá através da eficiência dos sistemas prediais hidráulicos e conseqüente redução na carga sobre a infra-estrutura de distribuição de água e coleta de esgotos sanitários.

\section{C) Conscientização dos usuários}

A relevância desse critério já foi discutida no item "Treinamento e conscientização dos usuários". Uma das áreas a ser tratada quando da elaboração do plano de treinamento dos usuários e de campanhas de conscientização é a importância da economia de água. Tais campanhas devem ser eficientes no sentido de sensibilizar os usuários e para isso, os mesmos 
devem ser identificados e caracterizados.

Castro apud Santos (2002a) alerta que as intervenções de ordem educacional devem conduzir os usuários a um comportamento tal que o posicionamento pessoal dos mesmos seja contrário ao desperdício. Segundo Silva e Gonçalves (s.d), existem vários meios para atingir os usuários em um programa de uso racional da água, como a distribuição de folhetos explicativos, cartazes, publicações em veículo de comunicação interna do edifício, distribuição de manuais de operação e manutenção dos equipamentos, além da realização de palestras de conscientização e de treinamento dos usuários.

O impacto de redução de cargas ambientais desse critério também se dá pela maior eficiência na operação dos sistemas prediais hidráulicos e sanitários, gerando como conseqüência uma redução na carga sobre a infra-estrutura de distribuição de água e coleta de esgotos sanitários.

\subsubsection{Carga na infra-estrutura local (drenagem pluvial)}

Todos os sistemas de avaliação de sustentabilidade ambiental de edifícios de escritório analisados propõem, em seus critérios de avaliação, a detenção de água pluvial no terreno durante o período de pico. No caso de haver a detenção, é importante ressaltar a possibilidade de utilização da água, o que será tratado de maneira mais aprofundada em 3.1.9.

\section{A) Disposição da água da chuva no terreno: detenção temporária}

Todos os sistemas de avaliação de sustentabilidade ambiental de edifícios estudados estabelecem uma pontuação relativa à prática da detenção de águas pluviais no período de pico das precipitações. Em algumas cidades brasileiras já existe a obrigatoriedade da 
construção de micro-reservatórios de detenção de água pluvial. Os micro-reservatórios de detenção são dispositivos armazenadores de água precipitada, que permitem a atenuação do pico dos hidrogramas de saída, recuperando a capacidade de amortecimento perdida devido à impermeabilização do solo (ANDRADE FILHO; SZÉLIGA; SZESZ, 2000).

Fendrich (2002) relata a necessidade da detenção temporária de águas pluviais para promoção de retardamento do escoamento superficial, contribuindo assim para o abatimento dos níveis de enchentes urbanas. Tucci (2003) também apresenta os reservatórios de águas pluviais implantados no terreno como uma das medidas de controle de inundações. Gonçalves (2004) propõe a simples detenção para posterior descarga no sistema de drenagem urbana ou a utilização da água armazenada para fins diversos, como irrigação paisagística, lavagem de superfícies e outros fins não-potáveis.

Silva (2003) propõe, para edifícios de escritórios no Brasil, dentre as medidas de gestão da água da chuva, já incorporadas no projeto, a previsão de reservatório enterrado e de sistema de retenção por criação de áreas alagáveis. O impacto de redução de cargas ambientais desse critério se dá pela redução na carga sobre a infra-estrutura de drenagem pluvial.

B) Disposição da água da chuva no terreno: infiltração no solo

Esse critério é mais um esforço no sentido de aliviar a carga na infra-estrutura local, porém desta vez, encorajando práticas que permitam a infiltração da água da chuva no solo. A infiltração pode ocorrer através da utilização de pavimentos permeáveis e/ou de dispositivos de drenagem que armazenam a água junto ao solo por tempo suficiente para que haja infiltração (ANDRADE FILHO; SZÉLIGA; SZESZ, 2000). Segundo Agra (2001), as principais medidas de infiltração da água pluvial no solo para controle de inundações são as seguintes: 
- trincheiras de infiltração: dispositivo de forma linear, preenchido por material granular, envolvido por filtro de geotêxtil;

- valas de infiltração: depressão linear, gramada ou com solo nu, que funciona como um canal, desacelerando o escoamento e possibilitando infiltração parcial;

- poços de infiltração: estrutura pontual e vertical, que possibilita a infiltração de forma radial no solo, podendo ser preenchida com material poroso ou não; e

- pavimentos permeáveis: superfície permeável que desvia parte do escoamento para leito de pedras localizado sob a superfície do terreno.

Algumas vantagens da infiltração, segundo Urbonas e Stahre apud Tucci (2003), são o aumento da recarga do aqüífero, redução da poluição transportada para rios e redução de vazões máximas a jusante.

Silva (2003), dentre as medidas de gestão da água da chuva, propõe que sejam utilizados pavimentos permeáveis de modo a possibilitar uma taxa maior de infiltração no solo. O impacto de redução de cargas ambientais desse critério se dá pela redução na carga sobre a infra-estrutura de drenagem pluvial.

C) Recuperação e tratamento de água de escoamento superficial

Dois dos sistemas de avaliação de sustentabilidade ambiental de edifícios de escritório analisados (LEED e CSTB) sugerem que haja o gerenciamento das águas de escoamento superficial, avaliando as disposições no sentido de recuperação das águas potencialmente poluídas e do tratamento em função de sua natureza antes do descarte ou utilização. Nesse caso, novamente é importante ressaltar a possibilidade de utilização da água tratada. Gonçalves et al. (2005) recomendam o aproveitamento de água de drenagem de terrenos (em vez do lançamento em rede pública) quando há controle da qualidade dessa água para que 
não haja riscos à saúde pública nem ao meio ambiente. Devem, porém, ser levados em consideração os riscos de contaminação por fontes externas. Vivacqua (2005) constatou em sua pesquisa a possibilidade de utilização de águas de escoamento superficial para diversos fins (após verificação de qualidade e tratamento), ressaltando a importância econômica e ambiental de tal prática. O impacto de redução de cargas ambientais desse critério se dá pela redução na carga de poluição da água e do solo.

\subsubsection{Carga na infra-estrutura local (tratamento de efluentes)}

A) Observação do padrão de qualidade exigido pela legislação local para os efluentes

Um problema no que concerne ao tratamento de efluentes, segundo Santos (2002b), é a questão da coleta integrada de esgotos sanitários domésticos e industriais e de águas pluviais. Com isso, há grande variabilidade na concentração dos principais poluentes, o que pode prejudicar o funcionamento das estações de tratamento. Os efluentes industriais coletados em conjunto com efluentes domésticos podem apresentar poluentes para os quais as estações de tratamento de esgotos domésticos não estão projetadas para tratar de maneira eficaz. Desta maneira, para que haja lançamento de efluentes de origem não doméstica no sistema público de coleta e tratamento, o referido autor sugere que seja realizado um prétratamento ou tratamento completo.

O lançamento de águas pluviais no sistema de coleta e tratamento de esgotos resulta em um efluente mais diluído, o que, segundo o referido autor, pode sobrecarregar o sistema em termos de vazão e diminuir sua eficiência. A NBR 8160 (ABNT, 1999) estabelece que não haja nenhuma ligação entre o sistema predial de esgoto sanitário e o sistema predial de águas pluviais. ABNT (1997) atesta a possibilidade de lançamento de esgoto sanitário, após 
tratamento adequado, em galerias de águas pluviais, se atender aos seguintes requisitos:

- o efluente deve possuir padrões físico-químico-biológicos de lançamento no corpo hídrico receptor da galeria em questão;

- o efluente deve sofrer desinfecção anterior ao lançamento;

- o empreendedor deve receber autorização pelo órgão competente para que haja o lançamento e

- o efluente deve alcançar padrão mínimo, conforme tabela 3.1 (tais parâmetros devem ser verificados em pelo menos $80 \%$ das amostras coletadas ao longo de 12 meses, em intervalos regulares).

Tabela 3.1 - Valores para lançamento de efluentes tratados em galerias de águas pluviais

Fonte: ABNT, 1997.

\begin{tabular}{|c|c|}
\hline Parâmetro & Valor \\
\hline DBO $_{5,20}$ & Inferior a $60 \mathrm{mg} / \mathrm{L}$ \\
\hline $\mathrm{DQO}$ & Inferior a $150 \mathrm{mg} / \mathrm{L}$ \\
\hline $\mathrm{pH}$ & Entre 6,0 e 9,0 \\
\hline Temperatura & Inferior a $40^{\circ} \mathrm{C}$ \\
\hline Óleos e graxas & Inferiores a $50 \mathrm{mg} / \mathrm{L}$ \\
\hline Oxigênio dissolvido & Superior a $1,0 \mathrm{mg} / \mathrm{L}$ \\
\hline Sólidos sedimentáveis & Inferior a $0,5 \mathrm{mg} / \mathrm{L}$ \\
\hline Sólidos não filtráveis totais & Inferior a $50 \mathrm{mg} / \mathrm{L}$ \\
\hline Coliformes fecais & $<1.000 \mathrm{NMP} / 100 \mathrm{~mL}$ \\
\hline Cloro residual livre & Superior a $0,5 \mathrm{mg} / \mathrm{L}$ \\
\hline
\end{tabular}

O que ocorre também, em muitas cidades brasileiras, é o não-atendimento por parte da rede pública de coleta, de parte do município ou do município como um todo. Em outros casos, mesmo quando há coleta, não há posterior tratamento e o efluente é lançado em corpos hídricos sem nenhum tipo de tratamento. Segundo Santos e Câmara (2002), os dados do ano de 2000, do Instituto Brasileiro de Estatística e Geografia mostram que apenas 54,50\% da população brasileira residem em domicílios ligados a um sistema de coleta de esgotos que os conduzem a um desaguadouro geral. Dessa parcela, apenas uma parte possui sistema que 
dispõe de estação de tratamento de efluentes.

Para a coleta de esgoto sanitário em rede pública, o padrão de qualidade do efluente deve estar dentro do exigido pela legislação local. No caso da não existência de rede pública de coleta, deve ser previsto um sistema de tratamento dos efluentes do edifício in loco que atenda, da mesma maneira, a legislação local pertinente.

A resolução $n^{0} 357$ do Conselho Nacional do Meio Ambiente (CONAMA) estabelece que os efluentes de qualquer fonte poluidora somente poderão ser descartados em corpos d'água (direta ou indiretamente), se obedecerem a condições estabelecidas, como pH, temperatura, vazão, proporção de materiais sedimentáveis e de óleos e graxas (BRASIL, 2005).

A referida resolução também estabelece padrões de lançamento de efluentes, relacionando substâncias orgânicas e inorgânicas com o respectivo valor máximo permitido por litro de efluente. O impacto de redução de cargas ambientais desse critério se dá pela redução na carga sobre a infra-estrutura de coleta e tratamento de esgotos sanitários.

\subsubsection{Interferência do edifício em aqüíferos subterrâneos, áreas inundadas e cursos d'água}

A) Manutenção das características da água em aqüíferos subterrâneos, áreas inundadas e cursos d'água localizados no terreno

Segundo Hespanhol e Gonçalves (2004), a cobrança pela utilização ou poluição de corpos hídricos induz à economia de água, redução de perdas e de poluição e à gestão com justiça ambiental. Os autores citam a Lei $n^{0} 6.938 / 81$ que prevê a possibilidade de imposição ao poluidor e ao predador, de indenização e/ou da recuperação de danos causados ao meio ambiente.

A Lei no 9.433 (BRASIL, 1997) instituiu a Política Nacional de Recursos Hídricos. 
Tal política objetiva assegurar a disponibilidade de água (dentro dos padrões de uso requeridos) à atual e às futuras gerações. Para tanto, um dos instrumentos da referida lei é a cobrança, não só pela captação de água de aqüíferos e corpos d'água, como pelo lançamento de efluentes nos mesmos. No último caso, não só o volume é considerado, como também as características físico-químicas e biológicas do esgoto e demais resíduos líquidos e gasosos lançados.

O impacto de redução de cargas ambientais desse critério se dá pela redução na carga de poluição da água e do solo.

B) Localização do terreno: distância mínima de corpos d'água

No Brasil, as Leis Federais no 4.771 (BRASIL, 1965) e 7.803 (BRASIL, 1989) consideram áreas de preservação permanente as faixas de terra situadas ao longo dos rios ou de qualquer curso d’água (desde o seu nível mais alto), com a largura mínima da faixa marginal variando de acordo com a largura do curso d'água, conforme tabela 3.2:

Tabela 3.2 - Largura da faixa marginal de preservação permanente em função da largura do curso d'água

\begin{tabular}{|c|c|}
\hline $\begin{array}{c}\text { Largura curso } \\
\text { d'água }\end{array}$ & $\begin{array}{c}\text { Largura mínima da } \\
\text { faixa de preservação }\end{array}$ \\
\hline Até $10 \mathrm{~m}$ & $30 \mathrm{~m}$ \\
\hline 10 a $50 \mathrm{~m}$ & $50 \mathrm{~m}$ \\
\hline 50 a $200 \mathrm{~m}$ & $100 \mathrm{~m}$ \\
\hline 200 a $600 \mathrm{~m}$ & $200 \mathrm{~m}$ \\
\hline Maior que $600 \mathrm{~m}$ & $500 \mathrm{~m}$ \\
\hline \multicolumn{2}{|c|}{ Fonte: BRASIL (1989). } \\
\hline
\end{tabular}

No caso de nascentes e "olhos d'água", a área de preservação permanente se situa em um raio mínimo de 50 metros. A resolução no 004 do CONAMA classifica como reservas ecológicas esta faixa de 50 metros em nascentes permanentes ou temporárias, com o objetivo de proteger a bacia de drenagem contribuinte (BRASIL, 1985).

A referida resolução classifica como reservas ecológicas também as florestas e demais 
formas de vegetação natural situadas ao longo dos rios e corpos d'água, respeitando os seguintes limites:

- 5 metros para corpos d'água com até 10 metros de largura;

- igual à metade da largura para corpos d'água com 10 a 200 metros de largura e

- 100 metros para corpos d'água com mais de 200 metros de largura.

Dessa forma, parte da área de preservação permanente, definidas pelas Leis $\mathrm{n}^{\circ} 4.771 \mathrm{e}$ 7.803, também é considerada reserva ecológica pela resolução $\mathrm{n}^{\circ} 004$ do CONAMA. Tal resolução considera reservas ecológicas, áreas ao redor de lagoas, lagos ou reservatórios naturais ou artificiais de água com as seguintes faixas marginais:

- 30 metros para os que estejam situados em áreas urbanas;

- 50 metros para os que estejam situados em áreas rurais e tiverem área superficial de até 20 hectares;

- 100 metros para os que estejam situados em áreas rurais e tiverem área superficial maior que 20 hectares e

- 100 metros para represas hidrelétricas.

A preservação da vegetação é fundamental para a proteção dos corpos d'água, contribuindo para a estabilização das margens, para redução do assoreamento e para a manutenção da qualidade da água (BARROS et al., 2003). O impacto de redução de cargas ambientais desse critério se dá pela redução na carga de poluição da água e do solo, além dos benefícios ambientais citados anteriormente.

Ainda segundo Barros et al., a legislação vigente é suficiente para proteção do meio ambiente e dos recursos naturais. O principal problema apontado, porém, é a falta de cumprimento e a falta de fiscalização pelas autoridades competentes. 


\subsubsection{Materiais componentes dos sistemas prediais hidráulicos e sanitários}

A) Escolha integrada dos produtos, sistemas e processos construtivos de modo a limitar os impactos ambientais

De acordo com o CSTB, o empreendedor deve fazer um cálculo da carga ambiental sobre recursos energéticos, não energéticos, mudanças climáticas, acidificação atmosférica e dejetos sólidos para famílias de produtos a serem avaliadas. A Certificação cita a norma francesa NF P01-010, relativa a cargas ambientais dos produtos da construção (sua contribuição a diferentes impactos ambientais, inclusive emissões poluentes na água e o volume consumido de água).

Segundo Ramos (2001), o impacto ambiental de um produto pode ser devido ao uso de recursos não-renováveis; ao método de extração de materiais que compõem o produto; ao consumo de energia e geração de emissões e resíduos na fase de fabricação, distribuição e transporte; às emissões durante a fase de utilização e à contaminação do solo após descarte. $\mathrm{O}$ referido autor incentiva a utilização de análise do ciclo de vida para escolha de produtos, porém a reconhece como uma metodologia cara e complexa, que carece de desenvolvimento.

Segundo CIB (1999), a escolha dos materiais deve ser feita com base no desempenho ambiental do material, em sua vida útil e em suas conseqüências à saúde humana. ABNT (2004b) recomenda a utilização de materiais que causem menor impacto ambiental, considerando desde a exploração dos recursos naturais até o destino final do material. A decisão, através do conhecimento do impacto ambiental, deve estar pautada na análise do ciclo de vida de cada produto, a ser disponibilizado pelos respectivos fabricantes.

A redução de cargas ambientais através desse critério se dá pela redução da utilização de recursos, que inclui matéria-prima, energia, $\mathrm{CO}_{2}$ incorporado, além da poluição da água e 
do solo.

B) Adequação à legislação e às normas técnicas locais

Segundo a NBR 5626 (ABNT, 1998), nos sistemas prediais de distribuição de água, a escolha dos materiais deve garantir, em primeiro lugar, a potabilidade da água. A segunda premissa é que as características da água e do meio em que o sistema esteja inserido não afetem o seu desempenho. Por último, o desempenho também deve ser adequado quando houver submissão às solicitações de uso. A corrosão e a degradação dos materiais também devem ser consideradas e a especificação deve ser feita de modo que tais problemas sejam evitados.

A referida norma cita ainda que o chumbo não deve ser utilizado nos sistemas que transportam água potável devido à possibilidade de liberação de material, o que resultaria em concentração de chumbo acima do permitido pelo padrão de potabilidade. Quanto ao emprego de materiais plásticos, a recomendação é a observação da temperatura, que pode danificar os componentes. De uma maneira geral, o emprego de materiais mencionados ou não pela referida norma pode ocorrer, desde que os princípios da mesma sejam obedecidos.

Para os sistemas prediais de coleta de esgotos sanitários, os materiais devem ser especificados em função das características do efluente (como temperatura, efeitos físicos e químicos). Também devem ser consideradas as solicitações mecânicas a que os componentes dos sistemas possam ser submetidos (ABNT, 1999).

A adequação dos materiais às normas locais deveria trazer redução de cargas de utilização de energia, de utilização de água e de materiais (recursos, energia, $\mathrm{CO}_{2}$ incorporado), de poluição, do efeito "ilha de calor", etc. Porém não se pode afirmar que de fato isso ocorra. Para tanto, deve haver um verificação das exigências referentes à escolha dos materiais inseridas na legislação e nas normas técnicas pertinentes, de modo a averiguar a 
utilização do conceito de análise do ciclo de vida.

\subsubsection{Reúso da água}

A) Utilização de águas servidas para usos benéficos no edifício

O que se pretende, primeiramente, ao praticar o reúso da água é a redução do consumo de água potável. Isso é possível através da utilização de água não potável para usos que não requerem água com tal qualidade. Existem diversas possibilidades de utilização de águas servidas em um edifício de escritórios.

A prática do reúso da água vem ao encontro também de um outro objetivo relacionado aos sistemas de avaliação de sustentabilidade ambiental de edifícios de escritório analisados: a diminuição da carga sobre o sistema de tratamento de efluentes local.

CIB (1999) cita o reúso de água como alternativa para economia de água potável. Santos (2002a) recomenda a avaliação rigorosa da qualidade da água de reúso para atender aos usos previstos. Deve ser analisada também a viabilidade econômica da utilização de águas servidas, considerando a finalidade de utilização, já que, quanto maior o nível de exigência com relação à qualidade da água, maiores serão os custos de tratamento. O projetista deve analisar tais fatores para que não se corra o risco da inviabilização do sistema de reúso no edifício (SANTOS, 2002a).

O reúso da água traz redução de cargas ambientais pela economia de água potável e pela redução da carga sobre a infra-estrutura de distribuição de água e de coleta de esgotos sanitários. 


\subsubsection{Aproveitamento de água pluvial}

A) Utilização de água pluvial para usos benéficos no edifício

O objetivo do aproveitamento de águas pluviais também é a redução do consumo de água potável, já que a água da chuva também pode ser utilizada para usos que requerem parâmetros de qualidade da água inferiores aos da água potável. Silva (2003) propõe a utilização de águas pluviais para irrigação, analisando a parcela do consumo mensal de água para irrigação resultante da coleta e tratamento de água da chuva.

CIB (1999) também cita a utilização de água pluvial como alternativa para economia de água potável. Santos (2002a) recomenda a caracterização da qualidade da água pluvial coletada e o confronto com os requisitos necessários para atender aos usos previstos.

O aproveitamento de águas pluviais também vem ao encontro de um outro objetivo dos sistemas de avaliação de sustentabilidade ambiental de edifícios de escritório analisados, que é a diminuição da carga sobre o sistema de drenagem pluvial local. O aproveitamento de água pluvial traz redução das cargas ambientais através da economia de água potável e da redução da carga sobre a infra-estrutura de distribuição de água e de drenagem pluvial.

\subsection{OUTROS CRITÉRIOS CONTEMPLADOS NA DOCUMENTAÇÃO TÉCNICA E NA NORMALIZAÇÃO BRASILEIRA}

Como forma de complementar as exigências dos sistemas de avaliação existentes, a partir do estudo de fontes bibliográficas que tratam da área de sistemas prediais, é efetuada uma proposta de inclusão de critérios à lista avaliada por tais sistemas. A referida proposta é 
efetuada tomando-se como base a mesma classificação de categorias de desempenho apresentada anteriormente.

3.2.1 Confiabilidade, qualidade e manutenabilidade dos sistemas prediais hidráulicos e sanitários

A) Provisão de água com a qualidade requerida pelo usuário, com vazões, pressões e temperaturas adequadas ao uso e no horário em que o usuário necessita

Gonçalves (1997) afirma que o objetivo do projetista de um sistema predial deve ser a adequação do sistema às necessidades e exigências do usuário, e não o caso contrário, ou seja, dos usuários aos sistemas. A provisão de água com a qualidade requerida pelo usuário, com vazões, pressões e temperaturas adequadas ao uso é ponto fundamental para o atendimento de necessidades e exigências dos usuários dos sistemas prediais hidráulicos. Rosrud apud Farina (2003) propõe, entre os requisitos de desempenho para o sistema predial de água fria, a provisão de água na qualidade desejada, em vazão suficiente, à temperatura adequada, no momento em que o usuário desejar utilizá-la.

Santos (2002a) recomenda que os sistemas prediais hidráulicos sejam projetados de modo que as demandas relativas à vazão, pressão e qualidade nos pontos de consumo sejam atendidas. O autor menciona, como meios para que estes objetivos sejam atendidos, a verificação de volumes e cotas dos reservatórios, o atendimento das pressões dinâmicas mínimas de cada aparelho sanitário e o correto dimensionamento dos diâmetros das tubulações.

Para esse critério, o impacto de redução de cargas ambientais está na eficiência dos sistemas prediais hidráulicos do edifício, o que gera economia de água e, conseqüente, redução na carga de infra-estrutura de distribuição de água e de coleta de esgoto. 
B) Projeto dos sistemas prediais hidráulicos e sanitários de modo a evitar a geração de ruídos, grandes vibrações e sobrepressão nos componentes dos sistemas

Rosrud apud Farina (2003) estabelece como requisito de desempenho para os sistemas prediais, a não-geração de ruídos, grandes vibrações e golpes de aríete. Graça e Gonçalves (1986) apresentam os seguintes requisitos para os sistemas de suprimento de água, de equipamento sanitário e para o sistema de coleta de esgotos sanitários:

- ruído: restringir a níveis aceitáveis os ruídos produzidos pelo funcionamento dos sistemas;

- vibrações: restringir a ocorrência de vibrações dos equipamentos do sistema, de maneira a não causar desconforto e danos materiais.

Nesse caso, outros critérios elaborados pela ABNT, para medir o desempenho de edifícios habitacionais de até cinco pavimentos (ABNT, 2004a), também podem ser aplicados para garantir o desempenho dos sistemas prediais hidráulicos e sanitários de edifícios de escritórios. Um deles diz respeito à limitação de ruídos no edifício gerados pelos sistemas prediais hidráulicos. O critério utilizado é a limitação da velocidade de escoamento da água nos sistemas prediais de suprimento de água à velocidade proposta pela NBR 5626 (ABNT, 1998). A Norma Brasileira em questão estabelece o valor de $3,0 \mathrm{~m} / \mathrm{s}$ como velocidade máxima para o escoamento da água no sistema predial de água fria.

Outro critério, ligado à limitação de ruídos, citado pelo Comitê Brasileiro da Construção Civil, para garantir o desempenho de sistemas prediais hidráulicos e sanitários (ABNT, 2004a), verifica os ruídos gerados por vibrações. O critério de desempenho é o isolamento de tubulações, equipamentos e demais componentes sujeitos a esforços dinâmicos de modo que não sejam propagadas vibrações à estrutura de sustentação do edifício. 
Os ruídos gerados em sistemas prediais hidráulicos e sanitários não se restringem apenas ao ambiente sanitário, podendo causar incômodos aos ocupantes de outros ambientes no edifício. São diversas as fontes causadoras de ruídos nos sistemas prediais hidráulicos e sanitários, quais sejam (QUERIDO, 1993):

- vibrações nos sistemas elevatórios;

- escoamento de água em tubulações, conexões, caixas sifonadas, ralos e registros;

- fechamento repentino de componentes;

- choque da água com as superfícies de aparelhos de utilização e - deslocamento de bolsões de ar nas tubulações.

As causas de ruídos nos sistemas prediais hidráulicos e sanitários são (QUERIDO, 1993):

- distúrbios no fluxo de suprimento de água em tubulações, conexões e acessórios;

- distúrbios devido ao excesso de pressão no suprimento;

- distúrbios no escoamento quando do esvaziamento de aparelhos sanitários e

- distúrbios devido ao esguichamento e espargimento de água quando do enchimento ou uso de algum aparelho sanitário.

Segundo WHO apud Prado (2003), os efeitos adversos do ruído podem resultar em perda de capacidade funcional ou em perda de capacidade de compensar estresses ou em aumento da suscetibilidade de um organismo a efeitos prejudiciais de outras influências ambientais. Para ABNT (1987), alguns dos valores recomendados para o nível sonoro em escritórios são os seguintes (tabela 3.3): 
Tabela 3.3 - Intervalos apropriados para o nível de ruído ambiente, em dB(A), num recinto de edificação, conforme a finalidade mais característica de utilização desse recinto

\begin{tabular}{|l|c|}
\hline \multicolumn{1}{|c|}{ Tipo de recinto } & $\begin{array}{c}\text { Nível de ruído ambiente em } \\
\text { dB(A) }\end{array}$ \\
\hline Escritórios (salas de reunião) & $30-40$ \\
\hline Escritórios (salas de administração, gerência e projeto) & $35-45$ \\
\hline Escritórios (salas de computadores) & $45-65$ \\
\hline
\end{tabular}

Fonte: ABNT (1987)

$\mathrm{O}$ valor inferior da faixa representa o nível sonoro para conforto e o valor superior, o nível sonoro aceitável para a finalidade.

ABNT (2004a) ainda propõe que os componentes dos sistemas prediais hidráulicos não provoquem golpes e vibrações que impliquem em risco à sua estabilidade estrutural, limitando a sobrepressão no fechamento de válvulas de descarga a 0,2 MPa. Este critério tem por objetivo a não geração do golpe de aríete nas válvulas de descarga, o que não só traz a possibilidade de colapso no sistema de suprimento de água (podendo acarretar na descontinuidade de abastecimento de parte do edifício) como também gera níveis de ruídos inadequados nos ambientes.

Para esse critério, o impacto de redução de cargas ambientais está na eficiência dos sistemas prediais hidráulicos e sanitários do edifício. Podem ser levadas em consideração as cargas ambientais provenientes da possível necessidade de substituição de materiais e componentes dos sistemas (utilizando, com isso, recursos) no caso de projetos que não atendam a esse critério.

C) Projeto dos sistemas prediais hidráulicos e sanitários de modo a evitar a entrada de gases no interior do edifício

Santos (2002a) afirma que novas concepções, configurações e tecnologias referentes ao sistema predial de coleta de esgotos têm sido desenvolvidas para atender exigências e 
necessidades dos usuários, citando como requisitos a garantia de rápido escoamento das águas servidas e o impedimento de retorno dos gases ao interior do edifício. Graça e Gonçalves (1986) também propõem como requisito de desempenho a restrição de entrada de odores provenientes do sistema.

Yen, Cheng e Ho (2005) discorrem sobre a habilidade dos sistemas prediais de coleta de esgotos sanitários para a prevenção de doenças infecciosas, destacando a importância do subsistema de ventilação, da garantia de integridade dos fechos hídricos e da manutenção adequada dos sistemas.

ABNT (2004a) estabelece critérios que se relacionam ao impedimento do retorno de gases provenientes do sistema de coleta de esgotos ao ambiente. É o caso do requisito "ausência de odores provenientes da instalação de esgoto", que estabelece os seguintes critérios:

- estanqueidade aos gases por meio de desconectores: a altura do fecho hídrico dos desconectores de todos os aparelhos sanitários, incorporados ou independentes, antes ou após a descarga, deve ser igual ou superior a $50 \mathrm{~mm}$;

- liberação de gases a partir do sistema de ventilação: as extremidades dos tubos ventiladores situados na cobertura do edifício devem guardar distância da própria cobertura, das janelas e portas, de acordo com o previsto na norma NBR 8160. A NBR 8160 (ABNT, 1999) recomenda que a extremidade aberta de um tubo ventilador primário ou coluna de ventilação deve estar a, pelo menos, 0,30 metros da laje de cobertura do edifício (ou a 2,00 metros no caso de lajes utilizadas para fins além dos de cobertura) e não deve estar situada a menos de 4,00 metros de qualquer janela ou porta, salvo se elevada pelo menos 1,00 metro das vergas dos respectivos vãos. 
O impacto de redução de cargas ambientais também está na eficiência dos sistemas prediais hidráulicos e sanitários do edifício. O não atendimento desse critério pode levar à necessidade de substituição de materiais e componentes dos sistemas (utilizando, com isso, recursos) e gerando cargas ambientais pela utilização de materiais e geração de resíduos.

D) Segurança: aterramento da tubulação metálica, de equipamento, acessórios e de aquecedores elétricos

Com relação ao risco de choques elétricos, os sistemas prediais hidráulicos e equipamentos de aquecimento de água devem ser seguros aos seus usuários, quando em operação e no uso normal (ABNT, 2004a). Para tanto, todas as tubulações, equipamentos e acessórios metálicos devem ser direta ou indiretamente aterrados. Além disso, quando houver a utilização de aparelhos aquecedores elétricos, os mesmos devem ser interligados ao sistema de aterramento, através de condutor de proteção, e devem apresentar corrente de fuga menor que $15 \mathrm{~mA}$ (ABNT, 2004a).

Para esse critério, o impacto de redução de cargas ambientais está na eficiência dos sistemas prediais do edifício, que contribuem para a segurança contra incêndio, por exemplo, o que geraria como carga a poluição do ar.

\subsubsection{Saúde e qualidade sanitária da água}

A) Evitar respingamentos e a geração de aerossóis

Os aparelhos sanitários, peças de utilização e outros componentes dos sistemas prediais hidráulicos devem fornecer água de modo a que não ocorram respingamentos ou a geração de aerossóis. É uma patologia que pode ocorrer devido a peças de utilização que não apresentem o fornecimento de água com adequada dispersão do jato, louças sanitárias que não 
estejam de acordo com as normas técnicas pertinentes ou projetos que não respeitem os limites máximos de pressão estática.

A NBR 13.696 (1997), ao citar a possibilidade de reúso de água, recomenda que, se existir a possibilidade de aspiração de aerossóis por quaisquer usuários, os parâmetros para a água utilizada devem ser os seguintes:

- turbidez: inferior a 5;

- número de coliformes fecais: inferior a $200 \mathrm{NMP} / 100 \mathrm{ml}$;

- sólidos dissolvidos totais: inferior a $200 \mathrm{mg} / \mathrm{l}$;

- $\mathrm{pH}$ : ente 6,0 e 8,0 ;

- cloro residual entre $0,5 \mathrm{mg} / \mathrm{l}$ e $1,5 \mathrm{mg} / \mathrm{l}$.

Para esse critério, o impacto de redução de cargas ambientais está na eficiência dos sistemas prediais hidráulicos e sanitários do edifício. Devem ser levadas em consideração as cargas ambientais provenientes da possível necessidade de substituição de materiais e componentes dos sistemas (utilizando, com isso, recursos) no caso de especificações que não atendam a esse critério.

B) Evitar empoçamentos e refluxos

Os sistemas prediais hidráulicos e sanitários devem ser projetados e executados de modo a não permitir a contaminação biológica através da estagnação da água. Para tanto, os componentes dos sistemas não devem permitir empoçamentos de água que possam vir a se tornar foco do desenvolvimento de bactérias (ABNT, 2004a).

Santos (2002a) aborda essa questão destacando o sistema predial de água pluvial e os riscos de transmissão de doenças como leptospirose e dengue. Para minimizar riscos relacionados a essas doenças, o autor propõe que sejam atendidos requisitos de conforto e de 
segurança sanitária, ambos relacionados ao esgotamento rápido da água pluvial, evitando empoçamentos e refluxos.

ABNT (2004a) observa, quanto à possibilidade de contaminação por refluxo da água, que a separação atmosférica mínima deve atender às exigências da NBR 5626 (ABNT, 1998). O projeto observa ainda que banheiras com torneiras afogadas, torneiras com possibilidade de conexão para mangueiras, bidês, lavadoras de louça e de roupas, duchas e outros equipamentos que possam vir a funcionar com a extremidade em contato com a água servida devem ser dotados de dispositivo quebrador de vácuo, assim como caixas de descarga e reservatórios com alimentação afogada.

Para esse critério, o impacto de redução de cargas ambientais está na eficiência dos sistemas prediais, que leva à saúde pública.

C) Projeto dos reservatórios de modo a garantir a potabilidade da água

Os reservatórios de água devem ser fechados com tampas que impeçam a entrada de animais e corpos estranhos, além de líquidos que não a água potável. A superfície superior externa deve ter declividade mínima de 1:3000 no sentido das bordas, não permitindo o acúmulo de água sobre o reservatório. A tampa deve ser elevada, no mínimo, $10 \mathrm{~cm}$ em relação ao piso acabado. Os reservatórios de água potável devem permitir inspeção e limpeza, possuindo ainda dispositivos de extravasão, limpeza e ventilação com as respectivas extremidades dotadas de crivo de tela com malha fina (ABNT, 2004a).

Para esse critério, devem ser levadas em consideração as cargas ambientais provenientes da contaminação da água e do desperdício gerado ao inutilizar água com padrão de potabilidade. 


\subsubsection{Uso racional da água}

A) Paisagismo eficiente: projeto prevendo a utilização de espécies locais (redução da necessidade de irrigação)

Silva (2003), ao propor uma ferramenta de avaliação de sustentabilidade de edifícios de escritórios no Brasil, avalia a utilização de espécies da flora local para o projeto paisagístico do edifício. A referida autora afirma que esta prática melhora a biodiversidade e reduz a necessidade de irrigação. CIB (1999) também cita o paisagismo eficiente como forma de economizar água, recomendando o emprego de espécies de plantas que não necessitem de sistemas de irrigação. FGBC (2004) disponibiliza um checklist de ações sustentáveis no projeto de edifícios comerciais em que o paisagismo, baseado na utilização da água da chuva na maior parte do tempo, sem o emprego de sistemas permanentes para irrigação, é incentivado. O instituto ainda recomenda uma análise do solo e do clima para a determinação do projeto paisagístico com plantas adequadas à realidade local.

O impacto de redução de cargas ambientais desse critério se dá pela redução na carga sobre a infra-estrutura de distribuição de água e de drenagem pluvial.

B) Evitar o desperdício qualitativo

Santos (2002a) propõe como conceito de desperdício qualitativo de água o "volume de água potável que é inviabilizado qualitativamente para o consumo", ou seja, pode ocorrer a contaminação da água enquanto armazenada ou distribuída pelos componentes dos sistemas prediais, fazendo com que os padrões de potabilidade não sejam mais atendidos.

O autor menciona pontos de possível contaminação da água nos sistemas prediais hidráulicos:

- peças de utilização: através de retrossifonagem ocorre o contato da água potável com a água servida; 
- tubulação: quando não existe um posicionamento relativo adequado entre a tubulação do sistema predial de coleta de esgoto sanitário e a tubulação dos sistemas prediais de distribuição de água, pode haver a contaminação da água potável;

- metais: a contaminação pode ocorrer pela corrosão dos metais que constituem tubos, válvulas, registros ou outros componentes dos sistemas prediais de distribuição de água;

- reservatórios: a contaminação ocorre, na maioria dos casos, devido a falhas construtivas ou à deficiência de manutenção. Pode ocorrer infiltração de água não potável no reservatório e a entrada de pequenos animais (através do extravasor ou de falhas na vedação da tampa ou outro acesso). Outras causas de contaminação do reservatório são a poluição atmosférica devido à contaminação do ar por elementos tóxicos e partículas em suspensão, e à falta de limpeza periódica dos reservatórios.

ABNT (1993) preconiza que todos os componentes dos sistemas prediais e os materiais empregados nas execuções devem preservar o padrão de potabilidade da água. $\mathrm{O}$ impacto de redução de cargas ambientais desse critério se dá pela maior eficiência no uso da água. Deve-se levar em conta também que, permitir a contaminação de água potável tratada é desperdiçar energia.

C) Localização otimizada de aquecedores e isolamento da tubulação de água quente

FGBC (2004) incentiva a localização, na fase de projeto, do aquecedor de água de maneira otimizada e o isolamento da tubulação de água quente, contribuindo para que uma quantidade menor de água seja utilizada para uma mesma finalidade. Com a previsão da localização do aquecedor de maneira a minimizar as distâncias aos pontos de consumo de 
água quente, a quantidade de água desperdiçada, ao se abrir a válvula ou registro, é menor. Esta quantidade de água desperdiçada é relativa à quantidade de água dentro da tubulação que não está na temperatura esperada de uso (porém possui os parâmetros de qualidade requeridos) e irá para o sistema de coleta de esgoto sanitário sem ser utilizada.

O desperdício de água ocorre também quando não há isolamento adequado da tubulação de água quente, já que, da mesma maneira, como a água não está na temperatura requerida (porque perdeu calor para o ambiente ao longo da tubulação), esta água será descartada. Com o isolamento adequado, a água dentro da tubulação do sistema predial de água quente conserva o calor por um período de tempo maior, podendo ser utilizada também por um período de tempo maior. ABNT (1993) recomenda que o projeto e execução de tubulações, reservatórios de água quente e aquecedores sejam realizados de modo a racionalizar o consumo. A referida norma recomenda ainda a análise das perdas de calor em função dos materiais empregados e das técnicas de isolamento térmico.

O impacto de redução de cargas ambientais desse critério se dá pela economia de água, gerando como conseqüência uma redução na carga sobre a infra-estrutura de distribuição de água e coleta de esgotos sanitários.

\subsubsection{Materiais componentes dos sistemas prediais hidráulicos e sanitários}

A) Ergonomia: altura adequada dos aparelhos sanitários e adaptação ergonômica dos equipamentos

A análise ergonômica é baseada tanto em estudos de dados físicos e antropométricos como em avaliações fisiológicas, biológicas e psicossociais (SOUZA, 2000). Os aparelhos sanitários devem estar adequadamente instalados de modo que respeitem as alturas e espaços mínimos e máximos para o conforto ergonômico dos usuários. Entre os critérios de 
desempenho propostos pela ABNT (2004a), um vai ao encontro das necessidades de conforto na operação de sistemas prediais. É o critério que objetiva a adaptação ergonômica dos equipamentos, propondo que as peças de utilização (inclusive registros de manobra) possuam volantes com formatos e dimensões adequadas ao uso específico.

O impacto de redução de cargas ambientais desse critério se dá pela diminuição da necessidade de substituição de componentes que não proporcionem o conforto esperado (a substituição gera maior utilização de recursos materiais).

B) Resistência mecânica dos sistemas prediais hidráulicos e sanitários: resistências às solicitações mecânicas durante o uso

Os sistemas prediais hidráulicos e sanitários devem resistir às solicitações mecânicas da seguinte maneira (ABNT, 2004a):

- tubulações suspensas: as tubulações fixas no teto ou em outros elementos estruturais, assim como seus suportes ou fixadores, devem resistir cinco vezes ao peso próprio das tubulações cheias de água sem entrar em colapso.

- tubulações suspensas de recalque ou que transportem água quente: o critério é idêntico ao do item anterior, porém, quando as tubulações estiverem sujeitas a esforços dinâmicos significativos, estes deverão ser levados em consideração.

- peças de utilização e aparelhos sanitários: aparelhos sanitários, peças de utilização e seus componentes de suporte devem resistir às cargas de utilização sem apresentar fissuras ou avarias que comprometam o funcionamento. Da mesma forma, devem resistir às cargas limites sem atingir o estado de ruína. ABNT (2004a) indica as cargas de acordo com cada tipo de aparelho, conforme tabela 3.4. 
Tabela 3.4 - Cargas atuantes em aparelhos sanitários

\begin{tabular}{|c|l|c|c|}
\hline Tipo de & \multicolumn{2}{|c|}{$\begin{array}{c}\text { Aparelho } \\
\text { ou peça }\end{array}$} & \multicolumn{2}{|c|}{ Valor da Carga } \\
\cline { 3 - 4 } & Carga de utilização & Carga limite \\
\hline Carga & Bacia sanitária e bidê apoiados & $1,3 \mathrm{kN}$ & $2,2 \mathrm{kN}$ \\
\cline { 2 - 4 } vertical & Bacia sanitária e bidê suspensos & $2,4 \mathrm{kN}$ & $4,0 \mathrm{kN}$ \\
\cline { 2 - 4 } na área & Lavatório, pia e tanque & $0,8 \mathrm{kN}$ & $1,3 \mathrm{kN}$ \\
\cline { 2 - 4 } de uso & Torneira de lavatório, pia e tanque & $0,2 \mathrm{kN}$ & $0,3 \mathrm{kN}$ \\
\hline
\end{tabular}

Fonte: ABNT (2004a).

- tubulações aparentes: as tubulações aparentes, fixadas até 1,5 metros acima do piso, devem resistir a impactos de utilização sem sofrer perda de funcionalidade e a impactos limite sem que ocorra a ruína da tubulação. ABNT (2004a) indica os valores dos impactos conforme tabela 3.5.

Tabela 3.5 - Impactos atuantes em tubulações aparentes

\begin{tabular}{|l|c|c|}
\hline \multirow{2}{*}{$\begin{array}{c}\text { Tipo de } \\
\text { impacto }\end{array}$} & \multicolumn{2}{|c|}{ Energia } \\
\cline { 2 - 3 } Corpo mole & Impacto de utilização & Impacto limite \\
\hline Corpo duro & $120 \mathrm{~J}$ & $240 \mathrm{~J}$ \\
\hline
\end{tabular}

Fonte: ABNT (2004a).

Para esse critério, o impacto de redução de cargas ambientais também se dá pela diminuição da necessidade de substituição de componentes, o que geraria maior utilização de recursos materiais.

C) Segurança na utilização de peças e aparelhos: prevenção de ferimentos

ABNT (2004a) propõe dois critérios de desempenho para garantir a segurança na utilização de peças de utilização e aparelhos sanitários. O objetivo é assegurar a saúde dos usuários, prevenindo ferimentos e queimaduras decorrentes da manipulação de partes dos sistemas prediais hidráulicos e sanitários:

- prevenção de ferimentos decorrentes de cantos vivos ou superfícies ásperas: peças de utilização e demais componentes dos sistemas prediais hidráulicos e 
sanitários, que sejam manipuladas pelos usuários, não devem possuir cantos vivos ou superfícies ásperas.

- prevenção de ferimentos decorrentes de altas temperaturas das peças: a temperatura superficial das peças de utilização no sistema predial de água quente deve ser de, no máximo, $55^{\circ} \mathrm{C}$ para superfícies metálicas e de, no máximo, $65^{\circ} \mathrm{C}$ para superfícies não metálicas.

O impacto de redução de cargas ambientais desse critério se dá pela contribuição para saúde pública e na diminuição da necessidade de substituição de componentes, o que geraria maior utilização de recursos materiais.

D) Estanqueidade dos sistemas prediais hidráulicos e sanitários

Os sistemas prediais hidráulicos e sanitários devem ser estanques à água. ABNT (2004a) sugere os seguintes critérios relacionados à estanqueidade dos sistemas:

- estanqueidade das tubulações dos sistemas prediais de suprimento de água: as tubulações dos sistemas prediais de suprimento de água não devem apresentar vazamentos quando submetidas a uma pressão hidrostática 1,5 vezes maior que o valor da pressão previsto em projeto para a mesma seção em condições estáticas e, em nenhum caso, inferior a $100 \mathrm{kPa}$.

- estanqueidade das peças de utilização: as peças de utilização não devem apresentar vazamentos quando submetidas à pressão hidrostática de uso prevista em projeto.

- estanqueidade dos reservatórios de água: os reservatórios dos sistemas prediais hidráulicos não devem apresentar vazamentos quando submetidos à pressão hidrostática de uso prevista em projeto. 
- estanqueidade das tubulações dos sistemas prediais de esgoto sanitário e de águas pluviais: as tubulações dos sistemas prediais de esgoto sanitário e de águas pluviais não devem apresentar vazamentos quando submetidas, durante 15 minutos a uma pressão estática de $60 \mathrm{kPa}$ se o teste for realizado com água, ou de $35 \mathrm{kPa}$ se o teste for realizado com ar preenchendo a tubulação.

O impacto de redução de cargas ambientais desse critério se dá pela maior eficiência dos sistemas prediais hidráulicos, gerando economia de água e, como conseqüência, redução na carga sobre a infra-estrutura de distribuição de água, de coleta de esgotos sanitários e de drenagem pluvial.

E) Manutenção da potabilidade da água: utilização de materiais que evitem a contaminação da água

ABNT (2004a) propõe três critérios de desempenho relacionados aos materiais utilizados na fabricação dos componentes dos sistemas prediais hidráulicos, bem como aos materiais empregados na execução destes sistemas. O objetivo dos critérios é evitar a contaminação da água transportada pelos sistemas prediais, garantindo a potabilidade da água e evitando danos à saúde dos usuários. Se houver a possibilidade de algum material causar doenças aos usuários pela introdução de substâncias tóxicas ou impurezas na água potável transportada pelos sistemas prediais hidráulicos, o material não deve ser utilizado. Além disso, da mesma maneira, materiais que possam permitir o desenvolvimento de bactérias (ou outras atividades biológicas) que provoquem doenças nos usuários, não devem também ser utilizados. Para garantir estes dois requisitos, os critérios propostos são os seguintes (ABNT, 2004a): 
- seleção de vedantes: nas juntas das tubulações dos sistemas prediais de distribuição de água, não devem ser utilizados materiais como zarcão ou chumbo, bem como nenhum outro material de vedação que possa contaminar a água.

- limitação de metais pesados no PVC: os tubos de PVC do sistema predial de água fria devem obedecer ao disposto na NBR 5648 no que se refere à contaminação por metais pesados.

- evitar contaminação biológica: todo componente aparente dos sistemas prediais hidráulicos deve ser fabricado em material lavável e impermeável para evitar a impregnação de sujeira, o desenvolvimento de bactérias e atividades biológicas.

O impacto de redução de cargas ambientais desse critério se dá pela maior eficiência no uso da água, já que a contaminação de água potável tratada constitui desperdício não só de água, mas também de energia.

F) Durabilidade

Quanto à vida útil dos sistemas prediais hidráulicos e sanitários, ABNT (2004a) recomenda que a qualidade do projeto e da execução deve garantir sua durabilidade no que se refere à manutenção das funções essenciais durante a vida útil, em condições normais de uso e operação. Quanto à durabilidade dos materiais, equipamentos e peças, ABNT (2004b) propõe a divisão em três níveis de atendimento do critério:

- desempenho mínimo: vida útil de projeto $^{9}$ dos sistemas prediais hidráulicos e sanitários maior ou igual a 8 anos;

- desempenho intermediário: vida útil de projeto dos sistemas prediais hidráulicos e sanitários maior ou igual a 10 anos;

\footnotetext{
9 A ABNT (2004b) define vida útil de projeto como período estimado de tempo em que o componente, equipamento, instalação ou sistema construtivo atende aos critérios previstos na norma de desempenho, no respectivo nível informado pelo fornecedor, cumprido o programa de manutenção por este especificado, além de manutenções corretivas que se fizerem necessárias.
} 
- desempenho superior: vida útil de projeto dos sistemas prediais hidráulicos e sanitários maior ou igual a 12 anos.

O impacto de redução de cargas ambientais desse critério se dá pela elevação da vida útil de componentes, o que traz como conseqüência a economia de recursos materiais, incluindo energia para fabricação, $\mathrm{CO}_{2}$ incorporado e matéria-prima.

\subsection{LISTA DE VERIFICAÇÃO COM BASE NOS CRITÉRIOS DE AVALIAÇÃO DE SUSTENTABILIDADE AMBIENTAL DOS SISTEMAS PREDIAIS HIDRÁULICOS E SANITÁRIOS EM EDIFÍCIOS DE ESCRITÓRIOS PROPOSTOS}

Os sistemas de avaliação de sustentabilidade ambiental estudados geraram uma lista de critérios de avaliação dos sistemas prediais hidráulicos e sanitários em edifícios de escritório. Com base em fontes bibliográficas consultadas, foram propostos no presente capítulo outros critérios de avaliação de sustentabilidade ambiental de modo a complementar esta lista. A criação de uma lista de verificação tem o objetivo de inserir conceitos de sustentabilidade ambiental no projeto e execução de sistemas prediais hidráulicos e sanitários. Com o intuito de auxiliar os envolvidos na indústria da construção civil, quando da concepção dos sistemas prediais hidráulicos e sanitários de edifícios de escritório, foi proposta lista de verificação constante na tabela 3.6. 
Tabela 3.6 - Lista de verificação de ações de sustentabilidade ambiental para os sistemas prediais hidráulicos e sanitários em edifícios de escritórios
CRITÉRIO
OBSERVAÇÕES

\begin{tabular}{|c|c|c|}
\hline \multirow{9}{*}{ 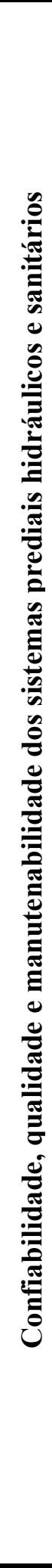 } & $\begin{array}{l}\text { Disponibilização de guia } \\
\text { informativo para o } \\
\text { administrador do edifício, com } \\
\text { dados sobre os sistemas prediais } \\
\text { hidráulicos e sanitários }\end{array}$ & $\begin{array}{l}\text { O guia deve conter informações sobre: } \\
\text { - condições de uso, operação e manutenção dos sistemas prediais } \\
\text { hidráulicos e sanitários e de seus componentes; conservação da água; } \\
\text { segurança, saúde e qualidade da água (como periodicidade de limpeza } \\
\text { de reservatórios, manutenção da potabilidade da água, laudos } \\
\text { necessários). } \\
\text { A NBR } 14037 \text { (ABNT, 1998) dá recomendações sobre o manual a ser } \\
\text { disponibilizado. }\end{array}$ \\
\hline & $\begin{array}{l}\text { Provisão de projetos "como } \\
\text { construído" dos sistemas } \\
\text { prediais hidráulicos e sanitários }\end{array}$ & $\begin{array}{l}\text { O projeto deve representar fielmente o que foi construído. A NBR } \\
14037 \text { (ABNT, 1998) cita a provisão do projeto as built. }\end{array}$ \\
\hline & $\begin{array}{l}\text { Treinamento e conscientização } \\
\text { dos usuários }\end{array}$ & $\begin{array}{l}\text {-Evitar acidentes e contaminações ocasionados pelo mau uso; permitir } \\
\text { completa utilização das funções dos componentes dos sistemas prediais } \\
\text { hidráulicos e sanitários; incentivar a economia de água. }\end{array}$ \\
\hline & $\begin{array}{l}\text { Uso de diferentes cores para } \\
\text { identificação dos sistemas } \\
\text { prediais que transportam água } \\
\text { não potável }\end{array}$ & $\begin{array}{l}\text { - uso de cores distintas nos sistemas que transportam água não potável } \\
\text { das cores empregadas no sistema que transporta água potável; } \\
\text { - emprego de placas indicativas nos reservatórios, na tubulação e nas } \\
\text { torneiras. }\end{array}$ \\
\hline & $\begin{array}{l}\text { Manutenabilidade: previsão de } \\
\text { dispositivos de fechamento dos } \\
\text { sistemas prediais de suprimento } \\
\text { de água de maneira setorizada e } \\
\text { de acesso para manutenção dos } \\
\text { sistemas prediais hidráulicos e } \\
\text { sanitários }\end{array}$ & $\begin{array}{l}\text { - previsão de dispositivos de fechamento dos sistemas prediais de } \\
\text { suprimento de água de maneira setorizada (no barrilete, nas colunas de } \\
\text { distribuição e nos ramais de distribuição de água); } \\
\text { - previsão de acesso para manutenção preventiva e corretiva dos } \\
\text { sistemas prediais hidráulicos e sanitários; } \\
\text { - previsão de acesso para limpeza de reservatórios de água. } \\
\text { A NBR 5626 (ABNT, 1998) dá recomendações sobre } \\
\text { manutenabilidade. }\end{array}$ \\
\hline & $\begin{array}{l}\text { Controle da manutenção da } \\
\text { temperatura da água no sistema } \\
\text { predial de água quente: previsão } \\
\text { de sistema de controle e gestão }\end{array}$ & $\begin{array}{l}\text { - aquecedores dotados de dispositivo automático de controle da } \\
\text { temperatura máxima admissível da água; } \\
\text { - aparelhos elétricos de acumulação providos de dispositivos de alívio } \\
\text { para o caso de sobrepressão e de dispositivo de segurança para o caso } \\
\text { de superaquecimento. } \\
\text { - temperatura máxima de saída da água aquecida, por equipamento de } \\
\text { aquecimento conforme ABNT (2004a). }\end{array}$ \\
\hline & $\begin{array}{l}\text { Confiabilidade: continuidade de } \\
\text { abastecimento }\end{array}$ & $\begin{array}{l}\text { - continuidade do fornecimento de água: o projeto dos sistemas prediais } \\
\text { de suprimento de água deve prever reservatórios compatíveis com o } \\
\text { número de usuários do edifício e com o tempo de interrupção do } \\
\text { fornecimento público; } \\
\text { - o volume de reservação de água que deve suprir as necessidades do } \\
\text { edifício conforme NBR } 5626 \text { (ABNT, 1998). }\end{array}$ \\
\hline & $\begin{array}{l}\text { Provisão de água com a } \\
\text { qualidade requerida, vazões, } \\
\text { pressões e temperaturas } \\
\text { adequadas ao uso e horário em } \\
\text { que o usuário necessita }\end{array}$ & $\begin{array}{l}\text { - fornecimento de água de maneira a proporcionar conforto aos } \\
\text { usuários, com temperatura, pressão, volume e vazão compatíveis com o } \\
\text { uso associado a cada ponto de utilização no momento em que o usuário } \\
\text { necessita. }\end{array}$ \\
\hline & $\begin{array}{l}\text { Projeto dos sistemas prediais } \\
\text { hidráulicos e sanitários de modo } \\
\text { a evitar a geração de ruídos, } \\
\text { grandes vibrações e } \\
\text { sobrepressão nos componentes } \\
\text { dos sistemas }\end{array}$ & $\begin{array}{l}\text { - restringir a níveis aceitáveis os ruídos produzidos pelo funcionamento } \\
\text { dos sistemas; } \\
\text { - restringir a ocorrência de vibrações dos equipamentos do sistema, de } \\
\text { maneira a não causar desconforto e danos materiais. } \\
\text { - limitação da velocidade de escoamento da água nos sistemas prediais } \\
\text { de suprimento de água a } 3,0 \mathrm{~m} / \mathrm{s} \text {; } \\
\text { - isolamento de tubulações, equipamentos e demais componentes } \\
\text { sujeitos a esforços dinâmicos de modo que não sejam propagadas } \\
\text { vibrações à estrutura de sustentação do edifício; } \\
\text { - limitação da sobrepressão no fechamento de válvulas de descarga a } \\
0,2 \mathrm{MPa}(\mathrm{ABNT}, 2004 \mathrm{a}) \text {. }\end{array}$ \\
\hline
\end{tabular}

continua 
continuação

CRITÉRIO

OBSERVAÇÕES

Projeto dos sistemas prediais $\quad$ - estanqueidade aos gases por meio de desconectores, de acordo com a hidráulicos e sanitários de modo a evitar a entrada de gases no interior do edifício NBR 8160 (ABNT, 1999);

- liberação de gases a partir do sistema de ventilação: as extremidades dos tubos ventiladores devem ser projetadas de acordo com a NBR 8160 (ABNT, 1999).

Segurança: aterramento da tubulação metálica, de equipamentos, acessórios e de aquecedores elétricos - aterramento direto ou indireto das tubulações, equipamentos e acessórios metálicos;

- aquecedores elétricos devem ser interligados ao sistema de aterramento através de condutor de proteção, além de apresentarem corrente de fuga menor que $15 \mathrm{~mA}$ (ABNT, 2004a).

\begin{tabular}{|c|c|c|}
\hline \multirow{6}{*}{ 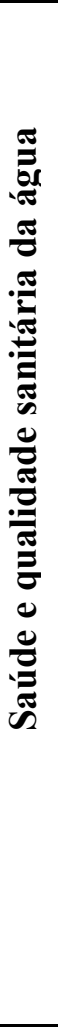 } & $\begin{array}{l}\text { Tratamentos anti corrosão e } \\
\text { anti incrustação nos sistemas } \\
\text { prediais de abastecimento de } \\
\text { água potável }\end{array}$ & $\begin{array}{l}\text { - previsão, em projeto, de materiais resistentes à corrosão e que } \\
\text { dificultem a formação de incrustações nos sistemas prediais de } \\
\text { abastecimento de água potável. }\end{array}$ \\
\hline & $\begin{array}{l}\text { Evitar respingamentos e a } \\
\text { geração de aerossóis }\end{array}$ & $\begin{array}{l}\text { - previsão de emprego de peças de utilização que apresentem o } \\
\text { fornecimento de água com adequada dispersão do jato e de louças } \\
\text { sanitárias que estejam de acordo com as normas técnicas pertinentes; } \\
\text { - projeto respeitando limites máximos de pressão estática. }\end{array}$ \\
\hline & Separação total dos sistemas & $\begin{array}{l}\text { - separação física dos sistemas prediais hidráulicos de qualquer sistema } \\
\text { que conduza água não potável ou fluido de qualidade questionável; } \\
\text { - assegurar que não ocorram ligações cruzadas do sistema de esgotos } \\
\text { sanitários ou de sistema que transporte água proveniente de fontes } \\
\text { alternativas com os sistemas prediais que transportam água potável. }\end{array}$ \\
\hline & $\begin{array}{l}\text { Minimização dos riscos de } \\
\text { contaminação por legionella } \\
\text { Pneumophila }\end{array}$ & $\begin{array}{l}\text { Os fatores de risco, segundo Van der Schee (2005), são temperatura da } \\
\text { água entre } 25^{\circ} \mathrm{C} \text { e } 50^{\circ} \mathrm{C} \text {; água estagnada; períodos longos sem a utilização } \\
\text { do sistema; sedimentação e formação de biofilme. }\end{array}$ \\
\hline & $\begin{array}{l}\text { Evitar empoçamentos e } \\
\text { refluxos }\end{array}$ & - não permitir a contaminação biológica através da estagnação da água. \\
\hline & $\begin{array}{l}\text { Projeto dos reservatórios de } \\
\text { modo a garantir a potabilidade } \\
\text { da água }\end{array}$ & $\begin{array}{l}\text { - os reservatórios devem ser fechados com tampas que impeçam a entrada } \\
\text { de animais e corpos estranhos, além de líquidos que não a água potável; } \\
\text { devem permitir inspeção e limpeza; possuir ainda dispositivos de } \\
\text { extravasão, limpeza e ventilação com as respectivas extremidades } \\
\text { dotadas de crivo de tela com malha fina; } \\
\text { - a superfície superior externa deve ter declividade mínima de } 1: 3000 \text { no } \\
\text { sentido das bordas, não permitindo o acúmulo de água sobre o } \\
\text { reservatório; a tampa deve ser elevada, no mínimo, } 10 \mathrm{~cm} \text { em relação ao } \\
\text { piso acabado (ABNT, 2004a). }\end{array}$ \\
\hline 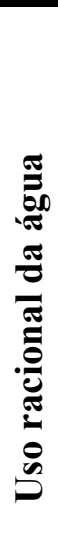 & $\begin{array}{l}\text { Utilização de equipamentos } \\
\text { economizadores }\end{array}$ & $\begin{array}{l}\text { Alguns equipamentos economizadores de água: } \\
\text { - torneira com funcionamento hidromecânico; } \\
\text { - torneira com sensor de presença; } \\
\text { - torneira com acionamento por válvula de pé; } \\
\text { - torneira com acionamento por pedal; } \\
\text { - torneira de comando restrito; } \\
\text { - arejadores; } \\
\text { - mictórios de acionamento hidromecânico; } \\
\text { - mictório com válvula de acionamento por sensor de presença; } \\
\text { - mictório com válvula de descarga temporizada; } \\
\text { - mictório sem água; } \\
\text { - bacias sanitárias com volume de descarga por acionamento igual a } 6 \\
\text { litros; } \\
\text { - bacias sanitárias com válvula de acionamento por sensor de presença; } \\
\text { - bacias sanitárias com caixa acoplada e sistema dual flush; } \\
\text { - dispositivos restritores de vazão. }\end{array}$ \\
\hline & Medição e monitoramento & $\begin{array}{l}\text { - previsão de medição setorizada ou individualizada do consumo de água; } \\
\text { - monitoramento, avaliação e correção de eventuais desperdícios e } \\
\text { vazamentos. }\end{array}$ \\
\hline
\end{tabular}

continua 
continuação

CRITÉRIO

OBSERVAÇÕES

\begin{tabular}{|c|c|c|}
\hline \multirow{4}{*}{ 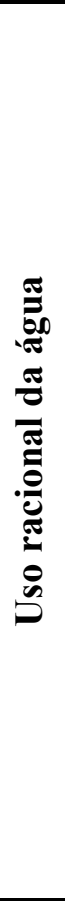 } & Conscientização dos usuários & $\begin{array}{l}\text { Pode ser realizada através de distribuição de folhetos explicativos sobre a } \\
\text { importância da economia de água, cartazes, publicações em veículo de } \\
\text { comunicação interna do edifício, realização de palestras de } \\
\text { conscientização e de treinamento dos usuários, além de informações no } \\
\text { próprio manual do usuário. }\end{array}$ \\
\hline & $\begin{array}{l}\text { Paisagismo eficiente: projeto } \\
\text { prevendo a utilização de } \\
\text { espécies locais (redução da } \\
\text { necessidade de irrigação) }\end{array}$ & $\begin{array}{l}\text { Utilização de espécies da flora local para o projeto paisagístico do } \\
\text { edifício, com o emprego de espécies de plantas que não necessitem de } \\
\text { sistemas de irrigação. }\end{array}$ \\
\hline & $\begin{array}{l}\text { Evitar o } \quad \text { desperdício } \\
\text { qualitativo }\end{array}$ & $\begin{array}{l}\text { - evitar a contaminação da água enquanto armazenada ou distribuída } \\
\text { pelos componentes dos sistemas prediais. Pontos de possível } \\
\text { contaminação da água nos sistemas prediais hidráulicos: } \\
\text { - peças de utilização: através de retrossifonagem ocorre o contato da água } \\
\text { potável com a água servida. } \\
\text { - tubulação: quando não existe um posicionamento relativo adequado } \\
\text { entre a tubulação dos sistemas prediais de distribuição de água potável e } \\
\text { outros sistemas. } \\
\text { - metais: a contaminação pode ocorrer pela corrosão dos metais que } \\
\text { constituem os componentes dos sistemas prediais hidráulicos. } \\
\text { - reservatórios: contaminação devido a falhas construtivas ou à } \\
\text { deficiência de manutenção. }\end{array}$ \\
\hline & $\begin{array}{l}\text { Localização otimizada de } \\
\text { aquecedores e isolamento da } \\
\text { tubulação de água quente }\end{array}$ & $\begin{array}{l}\text { - localização, na fase de projeto, do aquecedor de água de maneira } \\
\text { otimizada e isolamento da tubulação de água quente, contribuindo para } \\
\text { que menor quantidade de água seja utilizada para uma mesma finalidade. }\end{array}$ \\
\hline \multirow{3}{*}{ 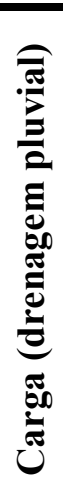 } & $\begin{array}{l}\text { Disposição da água da chuva } \\
\text { no terreno: detenção } \\
\text { temporária }\end{array}$ & $\begin{array}{l}\text { - detenção de águas pluviais de modo a aliviar a carga sobre a infra- } \\
\text { estrutura no horário de pico; } \\
\text { - em algumas cidades brasileiras existe a obrigatoriedade da construção } \\
\text { de dispositivos para detenção temporária de água pluvial. }\end{array}$ \\
\hline & $\begin{array}{l}\text { Disposição da água da chuva } \\
\text { no terreno: infiltração no solo }\end{array}$ & $\begin{array}{l}\text { - aliviar a carga na infra-estrutura local através de práticas que permitam } \\
\text { a infiltração da água pluvial no solo, que pode ocorrer através da } \\
\text { utilização de pavimentos permeáveis e/ou de dispositivos de drenagem } \\
\text { que armazenam a água junto ao solo para que haja infiltração. }\end{array}$ \\
\hline & $\begin{array}{l}\text { Recuperação e tratamento de } \\
\text { água de escoamento superficial }\end{array}$ & $\begin{array}{l}\text { - possibilidade de utilização de águas de escoamento superficial para } \\
\text { diversos fins após verificação de qualidade e tratamento (VIVACQUA, } \\
\text { 2005). }\end{array}$ \\
\hline
\end{tabular}

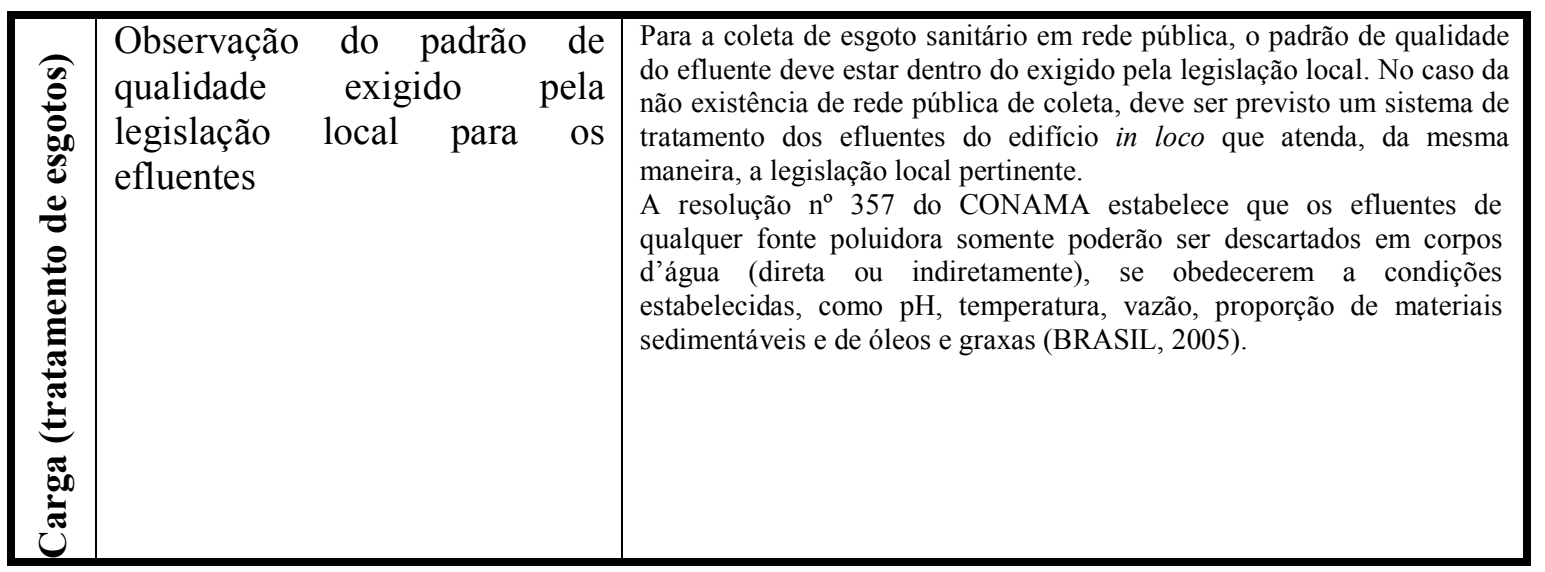

continua 
continuação

CRITÉRIO

OBSERVAÇÕES

\begin{tabular}{|c|c|}
\hline \multirow{2}{*}{ 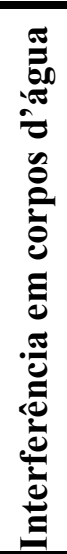 } & $\begin{array}{l}\text { Manutenção das características } \\
\text { da água em aqüíferos } \\
\text { subterrâneos, áreas inundadas } \\
\text { e cursos d'água localizados no } \\
\text { terreno }\end{array}$ \\
\hline & $\begin{array}{l}\text { Localização do } \\
\text { distância mínima de correno: } \\
\text { d'água }\end{array}$ \\
\hline
\end{tabular}

- controle de poluição e qualidade da água para evitar o comprometimento das características de aqüíferos subterrâneos e outros corpos d'água;

\begin{tabular}{|l|l}
\hline Escolha integrada dos & Analisar, quando da escolha dos produtos:
\end{tabular}

produtos, sistemas e processos $\quad$ - análise do ciclo de vida;

os impactos ambientais $\quad$ - acessibilidade e facilidade de manutenção;

- impactos ambientais da obra e

- impactos sanitários dos produtos (conforto e saúde dos usuários).

\begin{tabular}{l|l}
\cline { 2 - 2 } & Adequação à legislação e às
\end{tabular} normas técnicas locais

- cumprimento das normas locais que se referem aos materiais utilizados na execução dos sistemas prediais hidráulicos e sanitários assim como em todos os outros sistemas prediais.

Ergonomia: altura adequada - aparelhos sanitários devem estar adequadamente instalados de modo dos aparelhos sanitários e que respeitem as alturas e espaços mínimos e máximos para o conforto ergonômico dos usuários;

adaptação ergonômica dos equipamentos

- peças de utilização (inclusive registros de manobra) devem possuir volantes com formatos e dimensões adequadas ao uso específico.

Resistência mecânica dos sistemas prediais hidráulicos e sanitários: resistência às solicitações mecânicas durante o uso

Segurança na utilização de peças e aparelhos: prevenção de ferimentos

Os componentes dos sistemas prediais hidráulicos e sanitários devem ser resistentes às solicitações mecânicas de uso. Podem ser utilizados os requisitos propostos por $\mathrm{ABNT}$ (2004a).

- peças de utilização e demais componentes dos sistemas prediais hidráulicos que sejam manipuladas pelos usuários não devem possuir cantos vivos ou superfícies ásperas.

- temperatura superficial das peças de utilização no sistema predial de água quente deve ser de, no máximo, $55^{\circ} \mathrm{C}$ para superfícies metálicas e de, no máximo, $65^{\circ} \mathrm{C}$ para superfícies não metálicas (ABNT, 2004a).

Estanqueidade dos sistemas Os componentes dos sistemas prediais hidráulicos e sanitários não devem prediais hidráulicos e sanitários

Manutenção da potabilidade da água: utilização de materiais que evitem a contaminação da água

Ações para escolha de materiais que evitem a contaminação da água segundo ABNT (2004a):

- seleção de vedantes: nas juntas das tubulações dos sistemas prediais de distribuição de água não devem ser utilizados materiais como zarcão ou chumbo, bem como nenhum outro material de vedação que possa contaminar a água.

- limitação de metais pesados no PVC: os tubos de PVC do sistema predial de água fria devem obedecer ao disposto na NBR 5648 no que se refere à contaminação por metais pesados.

- evitar contaminação biológica: todo componente aparente dos sistemas prediais hidráulicos deve ser fabricado em material lavável e impermeável para evitar a impregnação de sujeira ou o desenvolvimento de bactérias ou atividades biológicas 
continuação

\begin{tabular}{|c|c|c|}
\hline & CRITÉRIO & OBSERVAÇÕES \\
\hline & Durabilidade & $\begin{array}{l}\text { - garantir durabilidade dos componentes dos sistemas prediais hidráulicos } \\
\text { e sanitários no que se refere à manutenção de suas funções essenciais } \\
\text { durante a vida útil, em condições normais de uso e operação. }\end{array}$ \\
\hline 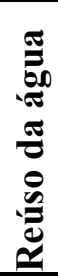 & $\begin{array}{l}\text { Utilização de águas servidas } \\
\text { para usos benéficos no edifício }\end{array}$ & $\begin{array}{l}\text { - utilização de água não potável para usos que não requerem água com tal } \\
\text { qualidade: emprego de sistemas de reúso da água (reduzindo o consumo } \\
\text { de água potável, o volume de efluentes e, conseqüentemente, a carga de } \\
\text { tratamento de esgoto). } \\
\text { - Monitoramento da qualidade e tratamento da água de reúso de acordo } \\
\text { com o uso previsto. }\end{array}$ \\
\hline 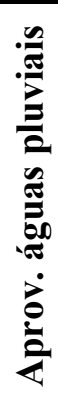 & $\begin{array}{l}\text { Utilização de águas pluviais } \\
\text { para usos benéficos no edifício }\end{array}$ & $\begin{array}{l}\text { - utilização de água não potável para usos que não requerem água com tal } \\
\text { qualidade: emprego de sistemas de aproveitamento de águas pluviais } \\
\text { (reduzindo a carga sobre os sistemas de suprimento de água potável e de } \\
\text { drenagem pluvial local). } \\
\text { - Monitoramento da qualidade e tratamento da água pluvial de acordo } \\
\text { com o uso previsto. }\end{array}$ \\
\hline
\end{tabular}

conclusão

O presente capítulo revê os critérios de avaliação de sistemas de avaliação de sustentabilidade ambiental analisados, verificando a normalização e documentação técnica pertinentes. Além disso, nesse capítulo propõe-se outros critérios para os sistemas prediais hidráulicos e sanitários, com base nessa revisão bibliográfica. O capítulo seguinte trata das considerações finais e recomendações, frutos do presente trabalho. 


\section{CONSIDERAÇÕES FINAIS}

A disponibilidade de água é fator essencial para o desenvolvimento de qualquer região. Para que haja a garantia de desenvolvimento sustentável, a disponibilidade de água precisa ser mantida com o tempo. No Brasil, a Política Nacional de Recursos Hídricos (BRASIL, 1997) qualifica a água como um bem de domínio público e recurso natural limitado, dotado de valor econômico. Na descrição dos objetivos de tal política, enfatiza-se a utilização racional dos recursos hídricos de modo a garantir que haja desenvolvimento sustentável.

Para a manutenção da disponibilidade de água torna-se necessário o gerenciamento do uso desse insumo que, em relação ao ambiente construído, está diretamente ligado aos sistemas prediais hidráulicos e sanitários. Daí a importância da avaliação de sustentabilidade ambiental quando do projeto e execução de tais sistemas.

Por sua vez, o ambiente construído está relacionado a uma grande parcela do impacto no meio ambiente, já que, além das necessidades materiais na etapa de construção (e posterior demolição), a maioria das atividades humanas é realizada em edifícios das mais diversas tipologias. Quanto à água, a importância de sua conservação está na impossibilidade de continuidade de vida sem este recurso.

O presente trabalho alcança seu objetivo principal com a proposição de critérios de avaliação de sustentabilidade ambiental dos sistemas prediais hidráulicos e sanitários em edifícios de escritórios, reunidos em uma lista de critérios, desenvolvida para ser utilizada quando do projeto e execução desses sistemas nessa tipologia de edifícios. Com isso, pretende-se inserir conceitos relacionados à sustentabilidade ambiental nos projetos e uma 
maior preocupação com o uso e conservação da água no ambiente construído. Para tanto, foram selecionados os métodos de avaliação de sustentabilidade ambiental de edifícios de escritórios BREEAM, LEED, GBTool, CSTB e CASBEE, e efetuada uma análise dos respectivos parâmetros de sustentabilidade, com foco na avaliação de itens relacionados aos sistemas prediais hidráulicos e sanitários e ao uso da água.

Por fim, com base na documentação técnica e normalização brasileira consultadas, foi efetuado um aprofundamento dos critérios de avaliação de sustentabilidade ambiental contemplados pelos métodos de avaliação estudados. Através de tal revisão bibliográfica chegou-se também a outros critérios, propostos nesse trabalho, de modo a complementar a lista inicial. A criação de uma lista de verificação para projeto tem o intuito de auxiliar os envolvidos na indústria da construção civil, quando da concepção dos sistemas prediais hidráulicos e sanitários de edifícios de escritórios. Os critérios foram divididos nas seguintes categorias:

- Confiabilidade, qualidade e manutenabilidade dos sistemas prediais hidráulicos e sanitários: trata de assuntos como a disponibilização de guia informativo e de projetos "como construído" quando da entrega da obra; treinamento dos usuários; garantia de continuidade de abastecimento e de segurança dos usuários; provisão de água com a qualidade requerida, com vazões, pressões e temperaturas adequadas; projeto de modo a evitar a entrada de gases no interior do edifício, a geração de ruídos, grandes vibrações e sobrepressão;

- Saúde e qualidade sanitária da água: trata de assuntos como a garantia de separação total dos sistemas e minimização dos riscos de contaminação; garantia de potabilidade da água; projeto de modo a evitar respingamentos e a geração de aerossóis, além de empoçamentos e refluxos; 
- Uso racional da água: apresenta maneiras para que haja economia de água potável através da utilização de equipamentos economizadores; emprego de sistema de medição e monitoramento e esforços de conscientização dos usuários;

- Carga na infra-estrutura local (drenagem pluvial): aborda a disposição da água pluvial no terreno, com detenção temporária e/ou infiltração no solo, além da recuperação e tratamento de água de escoamento superficial poluída;

- Carga na infra-estrutura local (tratamento de esgotos): observação do padrão de qualidade exigido pela legislação local para os efluentes;

- Interferência do edifício em aqüíferos subterrâneos, áreas inundadas e cursos d'água: aborda assuntos como a manutenção das características da água em aqüíferos subterrâneos, áreas inundadas e cursos d'água localizados no terreno e distância mínima do edifício de corpos d'água;

- Materiais componentes dos sistemas prediais hidráulicos e sanitários: aborda assuntos como a escolha integrada dos produtos, sistemas e processos construtivos; adequação à legislação e às normas técnicas locais; adaptação ergonômica dos equipamentos; resistência às solicitações mecânicas durante o uso; segurança na utilização de peças e aparelhos, estanqueidade, manutenção da potabilidade da água e durabilidade;

- Reúso da água: utilização de águas servidas para usos benéficos no edifício;

- Aproveitamento de águas pluviais: utilização de águas pluviais para usos benéficos no edifício. 
A lista de verificação, com critérios divididos nas categorias anteriormente citadas, objetiva trazer aspectos relacionados à sustentabilidade ambiental no ambiente construído, quando da concepção dos sistemas prediais hidráulicos e sanitários de edifícios de escritório. A avaliação de sustentabilidade ambiental é um passo importante para o desenvolvimento sustentável, porém devem ser realizados estudos mais aprofundados para futura inserção das outras dimensões da sustentabilidade em métodos de avaliação nos diversos países, inclusive no Brasil.

Para continuidade dos trabalhos, propõe-se o desenvolvimento de um método de avaliação de sustentabilidade ambiental de sistemas prediais hidráulicos e sanitários e do uso da água em edifícios de escritórios. Como ponto de partida para a realização do trabalho, a lista de critérios proposta no presente estudo pode ser utilizada. Para isso, a aderência e a importância relativa de cada um dos critérios propostos pode ser verificada através de consultas a envolvidos no setor da construção civil. Outra perspectiva para continuidade da pesquisa é a adaptação desta proposta a outras tipologias de edifícios. 


\section{REFERÊNCIAS BIBLIOGRÁFICAS}

AGRA, S. G. Estudo Experimental de Micro-reservatórios para Controle do Escoamento Superficial. Dissertação (Mestrado) - Instituto de Pesquisas Hidráulicas. Universidade Federal do Rio Grande do Sul. Porto Alegre, 2001.

ANDRADE FILHO, A. G.; SZÉLIGA, M. R.; SZESZ, J. R. Utilização de Microreservatórios de Detenção para Atenuação de Inundações em Bacias Urbanas. Universidade Estadual de Ponta Grossa. Ponta Grossa, 2000.

AMORIM, S. V. Metodologia para estruturação de sistemas de informação para projeto dos sistemas hidráulicos prediais, 1997. Tese (Doutorado em Engenharia Civil) Escola Politécnica da Universidade de São Paulo. São Paulo, 1997.

ARANTES, G. A. L. L. Modelo de Avaliação e Lista de Verificação para Projetos de Sistemas Hidrossanitários Prediais. 2003. Dissertação (Mestrado) - Universidade Federal de Santa Catarina, Florianópolis, 2003.

ASANO, Y. Forecast of Amount of Water Saving in Housing Complex and Amount of Carbon Dioxe Reduction According to it. In: CIB W062 Symposium 2005. Tokyo, 2005.

ASSOCIAÇÃO BRASILEIRA DE NORMAS TÉCNICAS - ABNT. NBR 10152: Níveis de Ruído para Conforto Acústico. Rio de Janeiro, 1987.

ASSOCIAÇÃO BRASILEIRA DE NORMAS TÉCNICAS - ABNT. NBR 7198: Projeto e execução de instalações prediais de água quente. Rio de Janeiro, 1993.

ASSOCIAÇÃO BRASILEIRA DE NORMAS TÉCNICAS - ABNT. NBR 8160: Sistemas Prediais de Esgoto Sanitário - Projeto e Execução. Rio de Janeiro, 1999.

ASSOCIAÇÃO BRASILEIRA DE NORMAS TÉCNICAS - ABNT. NBR 13969: Tanques Sépticos - Unidades de Tratamento Complementar e Disposição Final dos Efluentes Líquidos - Projeto, Construção e Operação. Rio de Janeiro, 1997.

ASSOCIAÇÃO BRASILEIRA DE NORMAS TÉCNICAS - ABNT. NBR 5626: Instalações Prediais de Água Fria. Rio de Janeiro, 1998.

ASSOCIACAO BRASILEIRA DE NORMAS TÉCNICAS - ABNT/CB-02. Desempenho de Edifícios Habitacionais de até 4 Pavimentos - Parte 8: Sistemas Hidro-Sanitários. Projeto 02:136.01.008, Rio de Janeiro, 2001. 
ASSOCIACAO BRASILEIRA DE NORMAS TÉCNICAS - ABNT/CB-02. Desempenho de Edifícios Habitacionais de até cinco Pavimentos - Parte 6: Sistemas Hidrossanitários. Projeto 02:136.01.008, Rio de Janeiro, 2004a.

ASSOCIACAO BRASILEIRA DE NORMAS TÉCNICAS - ABNT/CB-02. Desempenho de Edifícios Habitacionais de até cinco Pavimentos - Parte 1: Requisitos Gerais. Projeto 02:136.01.008, Rio de Janeiro, 2004b.

BALDWIN, R. et al. BREEAM 98 for Offices: an environmental assessment method for office buildings. Garston, 1998. 36 p.

BARROS, M. V. F. et al. Identificação das Ocupações Irregulares nos Fundos de Vale da Cidade de Londrina/PR por meio de Imagem Landsat 7. Revista RA'E GA., Curitiba, v. 7, p. 47-54, 2003.

BLUM, J. R. C. Critérios e padrões de qualidade da água. In: SANTOS, H. F.; MANCUSO, P. C. S. (org). Reúso de Água. Editora Manole. São Paulo, 2002, cap. 5, p. 125-174.

BRASIL. Conselho Nacional do Meio Ambiente. Resolução $n^{0} 004$ de 18 de setembro de 1985. Diário Oficial da União. Brasília, DF, 1985.

BRASIL. Conselho Nacional do Meio Ambiente. Resolução n 357 de 17 de março de 2005. Diário Oficial da União. Brasília, DF, 2005.

BRASIL. Lei $n^{\circ} 4.771$ de 15 de setembro de 1965. Institui o Novo Código Florestal. Diário Oficial da União. Brasília, DF, 1965.

BRASIL. Lei ${ }^{0} 7.803$ de 15 de julho de 1989. Altera a redação da Lei ${ }^{0} 4.771$, de 15 de setembro de 1965, e revoga as Leis $\mathrm{n}^{\mathrm{0}} 6.535$, de 15 de julho de 1978 e 7.511 , de 7 de julho de 1986. Diário Oficial da União. Brasília, DF, 1989.

BRASIL. Lei $\mathrm{n}^{\circ} 9.433$ de 8 de janeiro de 1997. Institui a Política Nacional de Recursos Hídricos. Diário Oficial da União. Brasília, DF, 1997.

BUILDING RESEARCH ESTABLISHMENT - BRE. BREEAM Offices 2004: Design and Procurement Assessment Prediction Checklist. Garston, 2003. 16 p.

CARDOSO, F. F. Certificação de Empreendimento Comercial de Elevado Desempenho Ambiental 2002 2 PCC USP / CSTB, São Paulo, 2003.

CENTRE SCIENTIFIQUE ET TECNIQUE DU BÂTIMENT - CSTB Référentiel de Certification Bâtiment Tertiaires: Démarche HQE Bureau et Enseinement. Paris, 2004.

COLE, R. J.; LARSSON, N. Review of GBTool and Analysis of GBC 2002 Case-Study Projects. Vancouver, 2002, $74 \mathrm{p}$.

CORREC, O.; DERRIEN, F.; DIAB, Y. An Original Tool to Investigate Drinking Water Distribution System. In: CIB W062 Symposium 2005. Tokyo, 2005. 
FARINA, H. Formulação de Diretrizes para Modelos de Gestão de Produção de Projetos de Sistemas Prediais. Dissertação (Mestrado) em Engenharia de Construção Civil. Escola Politécnica, Universidade de São Paulo. São Paulo, 2003.

FENDRICH, R. Aplicabilidade do Armazenamento, Utilização e Infiltração das Águas Pluviais na Drenagem Urbana. Tese (Doutorado) em Geologia. Universidade Federal do Paraná. Curitiba, 2002.

FLORIDA GREEN BUILDING COUNCIL. Florida Green Home Designation Standard Checklist. www.floridagreenbuilding.org, acesso em Abril de 2003.

GLOSSAIRE. Clermont-Ferrand: Agence Départementale d'Information sur le Logement du Puy de Dôme. Disponíel em <http://www.adil.org/63/reference/gloss.html $>$. Acesso em: 10 nov. 2005.

GONÇALVES, J. A. S. Planejamento Urbano e a Drenagem Urbana com melhoria de qualidade de vida em Ribeirao Preto - SP. Programa de Pós-Graduação em Engenharia Urbana. Universidade Federal de São Carlos. 2004.

GONÇALVES, O. M. Contribuições para a Economia e Qualidade dos Sistemas Prediais. São Paulo, 1997. Concurso de Livre Docência. Escola Politécnica, Universidade de São Paulo, 1997.

GONÇAlveS, O. M. et al. Conservação e Reúso da Água em Edificações. Prol Editora Gráfica. São Paulo, 2005.

GRAÇA, M. E. A.; GONÇALVES. O. M. Desempenho de Sistemas Sanitários Prediais: Conceitos Fundamentais. Revista de Engenharia Mackenzie. São Paulo, 1986.

GREEN BUILDING CHALLENGE - GBC. GBTool Overview. Vancouver. Disponível em $<$ http://greenbuilding.ca $>$. Acesso em: 15 jun. 2004.

HESPANHOL, I.; GONÇALVES, O. M. (org). Conservação e Reúso de Água: Manual de Orientações para o Setor Industrial - Volume 1. São Paulo, 2004.

HOFFMANN, M. A. Qualidade dos Recursos Hídricos da APA do Arroio Maestra Caxias do Sul. Dissertação (Mestrado) - Departamento de Geociências. Universidade Federal de Santa Catarina. Florianópolis, 2004.

INTERNATIONAL COUNCIL FOR RESEARCH AND INNOVATION IN BUILDING AND CONSTRUCTION - CIB. Agenda 21 on Sustainable Construction. CIB, [S.L.], 1999.

IOSHIMOTO, E.; OLIVEIRA, L. H.; GONÇALVES, O. M. Produtos Economizadores de Água nos Sistemas Prediais. DTA $n^{\circ}$ F2 do Programa Nacional de Combate ao Desperdício de Água. Brasília, 2004.

JAPAN SUSTAINABILITY BUILDING CONSORTIUM - JSCB. Comprehensive assessment system for building environmental efficiency - CASBEE. 2003. 
MAY, S. Estudo da Viabilidade do Aproveitamento de Água de Chuva para Consumo Não Potável em Edificações. Dissertação (Mestrado) - Engenharia de Construção Civil, Universidade de São Paulo. São Paulo, 2004.

MELO, A. R. Otimização do Reúso de Água em Lavadores Contínuos da Indústria Têxtil. Dissertação (Mestrado) - Centro Tecnológico. Universidade de Santa Catarina. Florianópolis, 2005.

NAVAROTTO, P. Risk Assessment on Use of Recycled Wastewater in Public Park Irrigation. Mediterranean Network on Wastewater Reclamation and Reuse. Barcelona, 2004.

NOVAES, C. C. Diretrizes para Garantia da Qualidade do Projeto na Produção de Edifícios Habitacionais. Tese (Doutorado) - Escola Politécnica da Universidade de São Paulo. São Paulo, 1996.

PRADO, R. T. A. (org.) et al. Execução e Manutenção de Sistemas Hidráulicos Prediais. Pini, São Paulo, 2000.

PRADO, R. T. A. Contribuição ao Estudo do Papel da Engenharia nas Interações entre o Homem, o Edifício e o Ambiente. Tese (Livre Docência) - Engenharia de Construção Civil e Urbana. Escola Politécnica da Universidade de São Paulo. São Paulo, 2003.

QUERIDO, J. G. Instalações Prediais Hidráulicas Sanitárias: Prognóstico de Ruídos. Tese (Doutorado) em Engenharia de Construção Civil. Escola Politécnica da Universidade de Sãso Paulo. São Paulo, 1993.

RAMOS, J. Alternativas para o Projeto Ecológico de Produtos. Tese (Doutorado) Engenharia de Produção. Universidade Federal de Santa Catarina. Florianópolis, 2001.

SANTOS, D. C. Os Sistemas Prediais e a Promoção da Sustentabilidade Ambiental. Ambiente Construído, Porto Alegre, 2002a.

SANTOS, G. J. Água de Reúso para Lavagem de Ruas e Rega de Parques. In: SANTOS, H. F.; MANCUSO, P. C. S. (org). Reúso de Água. Editora Manole. São Paulo, 2002c, p. 501511.

SANTOS, M. O. R. M. O Impacto de Cobrança pelo Uso da Água no Comportamento do Usuário. 2002. 231 p. Tese (Doutorado) - Departamento de Engenharia Civil, Universidade Federal do Rio de Janeiro, Rio de Janeiro, 2002b.

SANTOS, T. C. C.; CAMARA, J. B. D. (org). GeoBrasil 2002: Perspectivas do Meio Ambiente no Brasil. Edições Ibama. Brasília, 2002.

SAUTCHÚK, C. A. Código de Prática de Projeto e Execução de Sistemas Prediais de Água: Conservação de Água em Edifícios. DTA n ${ }^{\circ}$ F3 do Programa Nacional de Combate ao Desperdício de Água. Brasília, 2004.

SHOUlER, M. C. Water Efficient Appliances for Sustainable Buildings. In: CIB W062 Symposium 2005. Tokyo, 2005. 
SIlva, G. S; GOlÇAlVeS, O. M. Programas Permanentes de Uso Racional da Água em Campi Universitários: o Programa de Uso Racional da Água da Universidade de São Paulo. São Paulo, s.d. \{disponível em http://www.pura.poli.usp.br/download.htm acesso em 24 de junho de 2005 19:06h\}

SILVA, S. R. M. Indicadores de Sustentabilidade Urbana: as perspectivas e as limitações da operacionalização de um referencial sustentável. São Carlos, 2000. 260 p. Dissertação de Mestrado em Engenharia Urbana - Programa de Pós Graduação em Engenharia Urbana do Departamento de Engenharia Civil, Universidade Federal de São Carlos, 2000.

SILVA, V. G. Avaliação da Sustentabilidade de Edifícios de Escritórios Brasileiros: Diretrizes e Base Metodológica. 2003. Tese (Doutorado em Engenharia) - Escola Politécnica da Universidade de São Paulo, São Paulo.

SOUZA, R. V. G. Ergonomia e Ambiente Construído: uma análise de parâmetros de conforto ambiental. Disponível em <http://www.eps.ufsc.br/ergon/revista/resumos.htm>. Florianópolis, 2000.

TAMAKI, H. O. A Medição Setorizada como Instrumento de Gestão da Demanda de Água em Sistemas Prediais - Estudo de Caso: Programa de Uso Racional da Água da Universidade de São Paulo. 2003. Dissertação (Mestrado em Engenharia) - Escola Politécnica da Universidade de São Paulo, São Paulo.

TUCCI, C. E. M. Inundações e Drenagem Urbana. In: TUCCI, C. E. M.; BERTONI, J. C. (org.). Inundações Urbanas na América do Sul. Porto Alegre: Editora da Associação Brasileira de Recursos Hídricos, 2003. p.45-150.

UNITED STATES GREEN BUILDING COUNCIL - USGBC. LEED: Green Building Rating System for New Construction and Major Renovations version 2.1. San Francisco, 2002.

UNIVERSIDADE DE SÃo PAUlO. Programa de Uso Racional da Água. Disponível em http://www.pura.usp.br. Acesso em 20 de março de 2004.

VAN BELLEN, H. M. Indicadores de sustentabilidade: uma análise comparativa. 2002. 235 p. Tese (Doutorado em Engenharia de Produção) - Curso de Pós Graduação em Engenharia de Produção - Universidade Federal de Santa Catarina, Florianópolis, 2002.

VAN DER SCHEE, W. G. Regulation on Legionella Prevention in Colletive Water Systems. In: CIB W062 Symposium 2005. Tokyo, 2005.

VAN WOLFEREN, H. Legionella in Hot Tap Water Production. In: INTERNATIONAL ENERGY AGENCY. Proceedings IEA Workshop - Legionella. International Energy Agency. Holanda, 2001.

VIVACQUA, A. C. R. Qualidade da água do escoamento superficial urbano: revisão visando o uso local. Dissertação (Mestrado) - escola Politécnica da Universidade de São Paulo. São Paulo, 2005. 
YAMADA, E. S., PRADO, R. T. A, IOSHIMOTO, E. Os Impactos do Sistema Individualizado de Medição de Água. Boletim técnico da Escola Politécnica da Universidade de São Paulo. São Paulo: EPUSP, 2001.

YEN, C. J.; CHENG, A. L.; HO, J. R. Research of Infection Spread Risk Evaluation in Building Drainage System. In: CIB W062 Symposium 2005. Tokyo, 2005. 


\section{APÊNDICES}

APÊNDICE A - SISTEMAS PREDIAIS HIDRÁULICOS E SANITÁRIOS: USO E CONSERVAÇÃO DA ÁGUA

APÊNDICE B - ESTUDO PARA APLICAÇÃO DOS CRITÉRIOS DE AVALIAÇÃO DE SUSTENTABILIDADE AMBIENTAL DOS SISTEMAS PREDIAIS HIDRÁULICOS E SANITÁRIOS EM UM EDIFÍCIO DE ESCRITÓRIOS EM JOINVILLE - SANTA CATARINA 


\section{APÊNDICE A - SISTEMAS PREDIAIS HIDRÁUlICOS E SANITÁRIOS: USO E CONSERVAÇÃO DA ÁGUA}

Ao se pensar em construção sustentável, um dos aspectos mencionados em qualquer Agenda local é a necessidade de gestão do uso da água. No ambiente construído, através das atividades dos usuários, surgem algumas necessidades relacionadas à água que, por conseqüência, envolvem os sistemas prediais hidráulicos e sanitários.

Com a conscientização sobre a importância da preservação e da economia de água, várias iniciativas no sentido de uma utilização mais adequada desse insumo começaram a surgir. Os Programas de Uso Racional da Água - PURAs - objetivam a economia através de um menor consumo. Já os Programas de Conservação da Água - PCAs - têm o objetivo de gerar economia através de um consumo menor aliado ao uso de fontes alternativas de abastecimento. Desta maneira, os PURAs têm enfoque na demanda de água, enquanto os PCAs têm enfoque na oferta e na demanda (informação verbal) ${ }^{1}$. A figura 1 apresenta esquematicamente a relação entre um PURA e um PCA.

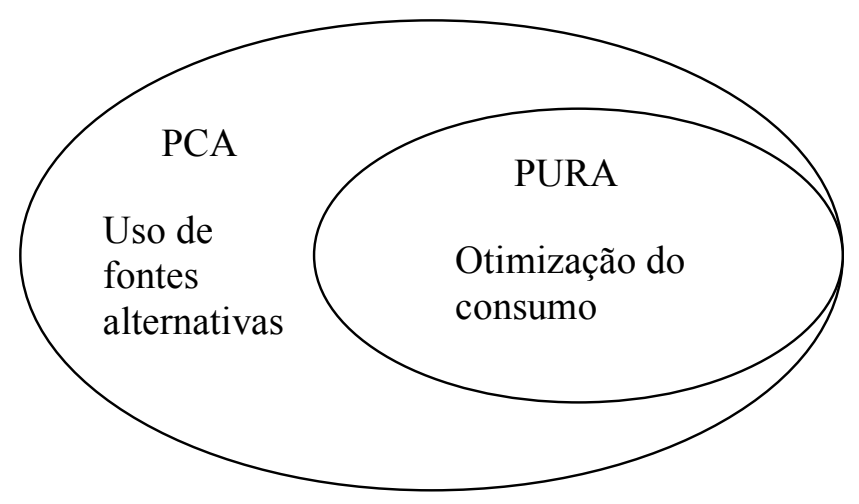

Figura 1 - Programa de Uso Racional de Água e Programa de Conservação da Água

\footnotetext{
${ }^{1}$ Palestra proferida pelo Professor Doutor Orestes Marracini Gonçalves, na Escola Politécnica da Universidade de São Paulo em 01 de abril de 2003.
} 


\section{USO RACIONAL DA ÁGUA}

Uso racional da água pode ser definido como "otimização em busca do menor consumo de água possível mantidas, em qualidade e quantidade, as atividades consumidoras" (GONÇALVES, 2002). Esta otimização do consumo de água pode ser alcançada com o planejamento e posterior implementação de ações para redução de desperdícios, ações essas que estejam de acordo com as necessidades e exigências dos usuários. As ações que contribuem para a redução de consumo de água em edifícios, segundo Oliveira (1999), podem ser divididas em:

- econômicas: podem ser incentivos econômicos, tais como subsídios para aquisição de sistemas e equipamentos e redução da tarifa conforme a diminuição do consumo; ou desincentivos econômicos como a elevação das tarifas de água;

- sociais: compreendem campanhas com o objetivo de conscientizar os usuários, mudando o comportamento dos mesmos frente o uso da água e

- tecnológicas: substituição de sistemas e componentes convencionais por economizadores de água, implantação de sistemas de medição setorizada do consumo de água, detecção e correção de vazamentos e reaproveitamento de água.

Oliveira e Gonçalves (1999) formularam uma proposta para implantação de um PURA estruturada em quatro etapas. Em uma primeira etapa, é realizada a auditoria no consumo de água. Os referidos autores propõem o levantamento de indicadores de consumo (IC) para evitar avaliações errôneas. O IC é a relação entre o volume de água consumido em um determinado período e o número de agentes consumidores nesse mesmo período. Nessa fase, 
um diagnóstico preliminar já pode ser realizado, comparando o Indicador de Consumo estimado e o Indicador de Consumo histórico (ICh) ${ }^{2}$.

Ainda na etapa de auditoria do consumo de água, é necessário um levantamento das características físicas e funcionais do sistema hidráulico e das atividades desenvolvidas pelos usuários no edifício.

Nesse levantamento deve ser efetuada a detecção dos vazamentos visíveis e não visíveis, utilizando testes expeditos (teste do hidrômetro) e especiais (correlacionador de ruídos, geofone eletrônico e haste de escuta).

A segunda etapa trata do diagnóstico do consumo de água no edifício, o que possibilita a elaboração de um plano de intervenção para ações específicas para cada tipologia de edifício e a consideração das características próprias de cada sistema. O diagnóstico deve conter pelo menos as seguintes informações (GONÇALVES et al., 2005; OLIVEIRA e GONÇALVES, 1999; OLIVEIRA, 1999):

- consumo diário de água no período histórico: volume total de água consumido (utilizado e desperdiçado), por dia, considerando determinado período histórico; - número de agentes consumidores: número total correspondente à variável adotada para a representação de volume consumido unitariamente na edificação, como por exemplo, pessoa, leito, aluno, etc.;

- valor do indicador de consumo de água no período histórico: relação entre o volume de água consumido em um determinado período e o número de agentes consumidores neste mesmo período;

- desperdício diário estimado: volume de perdas e de uso excessivo estimado por dia;

\footnotetext{
${ }^{2}$ Podem ser usados indicadores de consumo de edifícios de mesma tipologia ou da média de ICh antes do aumento do consumo de água no sistema (Oliveira e Gonçalves, 1999).
} 
- índice de desperdício estimado: relação entre o volume de perdas e de uso excessivo estimado em um determinado período e o volume total de água consumido no mesmo período;

- perda por vazamento visível: volume perdido, perceptível a olho nu, seja por escoamento ou gotejamento de água;

- índice de perda por vazamento visível: relação entre o volume total perdido em vazamentos visíveis em um determinado período de tempo e o consumo total de água neste mesmo período;

- índice de vazamento visível: relação entre o número de pontos de utilização que apresentam vazamento visível e o número total de pontos de utilização;

- perda por vazamento não-visível: volume perdido, não perceptível a olho nu, constatado por meio de indícios, como manchas de umidade, sons de escoamento, sistemas de recalque continuamente ligados, constante entrada de água em reservatórios, etc.;

- índice de perda por vazamento não-visível: relação entre o volume total perdido em vazamentos não-visíveis em um determinado período de tempo e o consumo total de água neste mesmo período;

- índice de vazamento não-visível: relação entre o número de pontos de utilização que apresentam vazamento não-visível e o número total de pontos de utilização;

- perda diária total levantada no sistema: volume total de água que escapa do sistema predial hidráulico antes de ser utilizada para uma atividade fim;

- consumo diário de água em sistemas especiais: volume de água consumido por dia em sistemas de ar condicionado, ar comprimido, vácuo, vapor com caldeira, hemodiálise por osmose reversa, e destilação, entre outros e 
- procedimentos inadequados dos usuários relacionados ao consumo de água: levantamento de procedimentos como banho prolongado, utilização de torneiras abertas ininterruptamente em atividades que não exijam tal uso, banhos prolongados, etc. Este levantamento pode ser realizado através de observação e de entrevistas.

O plano de intervenção é a terceira etapa. Através dele, são pensadas as ações para a economia de água através da diminuição no consumo. Nessa etapa, ocorre a correção de vazamentos anteriormente detectados, a substituição de componentes convencionais por economizadores de água, a redução de perdas e reaproveitamento de água em sistemas hidráulicos especiais. Ainda nessa fase, segundo os autores, devem ocorrer campanhas de conscientização e educação dos usuários.

A quarta etapa é a avaliação do impacto de redução do consumo de água por agente consumidor, calculado através da equação 1:

$$
\mathrm{IR}=\frac{\mathrm{ICAP}-\mathrm{ICDP}}{\mathrm{ICAP}} \times 100(\%)
$$

Onde:

IR = impacto de redução de consumo de água por agente consumidor;

ICAP $=$ indicador de consumo de água antes do PURA e

ICDP = indicador de consumo de água depois do PURA.

Acredita-se que a implantação de PURAs acarrete no incentivo à pesquisa e desenvolvimento de produtos mais adequados, mais eficientes e que ajudam a utilizar uma quantidade cada vez menor de água para cumprir a finalidade a que se destinam. Além do aspecto que engloba pesquisa e desenvolvimento tecnológico, outro ponto importante na 
implantação dos PURAs é a conscientização dos usuários. Percebe-se que, quando alguém se conscientiza sobre a importância da economia de água no seu local de trabalho, por exemplo, acaba levando os conceitos adquiridos para a sua casa e para a sua família, passando a ser também um agente disseminador da idéia da importância da economia de água.

\section{USO DE FONTES ALTERNATIVAS DE ABASTECIMENTO}

O uso de fontes alternativas para o abastecimento de água depende da qualidade requerida para o uso final. Ou seja, é possível utilizar água com qualidade diferente dependendo do emprego que se dará a esta água (HESPANHOL, 2002). Alguns Órgãos, Agências e Associações definiram parâmetros para a água de reúso nos diferentes países. No Brasil, a Associação Brasileira de Normas Técnicas - ABNT, através da publicação da NBR 13.969 (1997), prevê a possibilidade de reutilização e indica os parâmetros que a água deve ter, conforme o tipo de uso final.

Blum (2002) afirma que, se a qualidade da água utilizada exceder os padrões de qualidade necessários para determinado uso ocorre um desperdício de recursos. Desta maneira, o que se pretende com o emprego de fontes alternativas de abastecimento é a otimização do uso da água através da utilização do conceito de substituição de fontes que, segundo Hespanhol (2002) é a alternativa mais plausível para atender a demandas menos restritivas. Ainda, segundo o referido autor, esta prática permite que as águas de melhor qualidade sejam empregadas para fins mais nobres.

Segundo Sautchúk (2004a), a escolha de fontes alternativas de abastecimento deve considerar não somente os custos de aquisição do sistema, porém também a necessidade de garantia da qualidade necessária a cada uso específico. Ou seja, é necessário um estudo para 
garantir a viabilidade econômica do sistema, além de se pensar na questão da gestão do uso da água, resguardando assim, a saúde dos usuários.

Dentre as fontes alternativas de abastecimento de água destacam-se a captação de águas subterrâneas, a captação direta em corpos hídricos, a água de reúso e o aproveitamento de águas pluviais. É importante ressaltar que a opção pelo emprego de fontes alternativas de abastecimento implica na responsabilidade pela gestão qualitativa e quantitativa da água. Desta maneira, qualquer que seja a fonte alternativa de abastecimento, deve haver um planejamento de modo que haja monitoramento contínuo da quantidade e da qualidade da água a ser utilizada (GONÇALVES et al., 2005). O reúso de água e o aproveitamento de água pluvial são apresentados de forma mais detalhada.

\section{Reúso de Água}

O reúso de água nada mais é que a utilização de uma quantidade de água já utilizada anteriormente. Esta prática pode ocorrer de maneira planejada ou não e de maneira direta ou indireta, segundo Lavrador Filho (1987):

- reúso não planejado indireto: o reúso não planejado indireto ocorre quando certa quantidade de água é - após ter sido utilizada, descartada e diluída em um corpo d'água - a jusante captada novamente e utilizada, sem que haja estudos, nem para seu despejo, nem para nova captação. Um exemplo seria o despejo do esgoto doméstico de uma ou mais residências em um riacho, que a jusante serviria de fonte de abastecimento para outras residências, de maneira não planejada.

- reúso planejado indireto: o reúso planejado indireto ocorre quando uma certa quantidade de água é - após ter sido utilizada, descartada e diluída em um corpo d'água - novamente utilizada, porém com estudos periódicos para a verificação da 
qualidade da água descartada e da água a ser novamente captada, após a diluição. Um exemplo desta forma de reúso seria uma empresa que trata seus efluentes e os deposita em um lago natural, utilizando esta água posteriormente para a lavagem dos veículos de sua propriedade.

- reúso planejado direto: o reúso planejado direto ocorre quando uma certa quantidade de água é, após utilizada, reutilizada para o mesmo ou para outro fim, sem ser diluída em outra fonte, conhecendo-se as suas características. Um exemplo desta prática é a captação da água de um ou mais aparelhos sanitários (exceto de bacias sanitárias e de pias de cozinha), seguida de tratamento, para ser utilizada na descarga das bacias sanitárias.

A prática do reúso da água é ponto importante para a sustentabilidade ambiental em várias regiões do mundo. Segundo Hespanhol (2002), “não há dúvida de que a utilização destes recursos hídricos não convencionais para usos benéficos diversos constitui prática de imenso valor potencial para diversas áreas do Brasil". O referido autor ainda cita a importância do reúso da água em regiões como o Nordeste semi-árido, e outras regiões em que a oferta de água é inviável economicamente, como ocorre nas grandes aglomerações metropolitanas.

No que diz respeito ao aspecto econômico da água, a partir da Constituição Federal de 1988, os corpos d'água não podem mais ser considerados propriedade privada, não sendo mais assegurado o uso gratuito de qualquer corrente ou nascente (FINK; SANTOS, 2002). Ainda, segundo os autores, "a gestão dos recursos hídricos, a gestão do uso da água por bacias hidrográficas e o conceito do usuário pagador conduzem a um novo enfoque que começa a ser efetivamente implantado a partir da promulgação da Lei $n^{\circ}$ 9.433/97, que institui a Política Nacional de Recursos Hídricos”. 
Os referidos autores ainda mencionam a possibilidade da cobrança pela captação da água (considerando a quantidade captada) e pelo lançamento do efluente (considerando não somente a quantidade a ser lançada, como também a qualidade do efluente). Este tipo de cobrança poderá estimular não apenas a economia de água através de um consumo menor, como também estimular a prática de tratamento de efluentes antes do descarte.

Existem vários empregos possíveis para a água de reúso. A NBR 13.969 (ABNT, 1997) recomenda que, no caso do esgoto de origem essencialmente doméstica ou com características similares, o esgoto tratado pode ser reutilizado para fins que exigem qualidade de água não potável, mas sanitariamente segura. Esta Norma ainda divide a água de reúso em classes, de acordo com seus parâmetros (como turbidez, coliformes fecais, pH, sólidos dissolvidos totais e cloro residual), indicando o uso possível:

a) Classe 1: lavagem de carros e outros usos em que há o contato com o usuário de forma direta. ABNT (1997) destaca ainda a possibilidade de aspiração de aerossóis pelo operador na lavagem de veículos ou até mesmo por transeuntes em chafarizes;

b) Classe 2: lavagem de pisos, irrigação de jardins, manutenção de canais e lagos para fins paisagísticos (excluindo chafarizes);

c) Classe 3: reúso nas descargas de bacias sanitárias e

d) Classe 4: reúso para irrigação de pomares, cereais, forragens, pastagens e outros cultivos através de escoamento superficial ou irrigação pontual. ABNT (1997) recomenda que as aplicações sejam interrompidas, pelo menos, nos dez dias anteriores à colheita para este tipo de reúso.

Quanto aos usos potenciais de esgotos tratados, Hespanhol (1999) expõe a possibilidade de utilização de esgoto de origem doméstica e industrial, na agricultura, 
aqüicultura, recreação, além de usos urbanos e industriais. Os tipos básicos de usos potenciais de esgotos tratados são apresentados na figura 2.

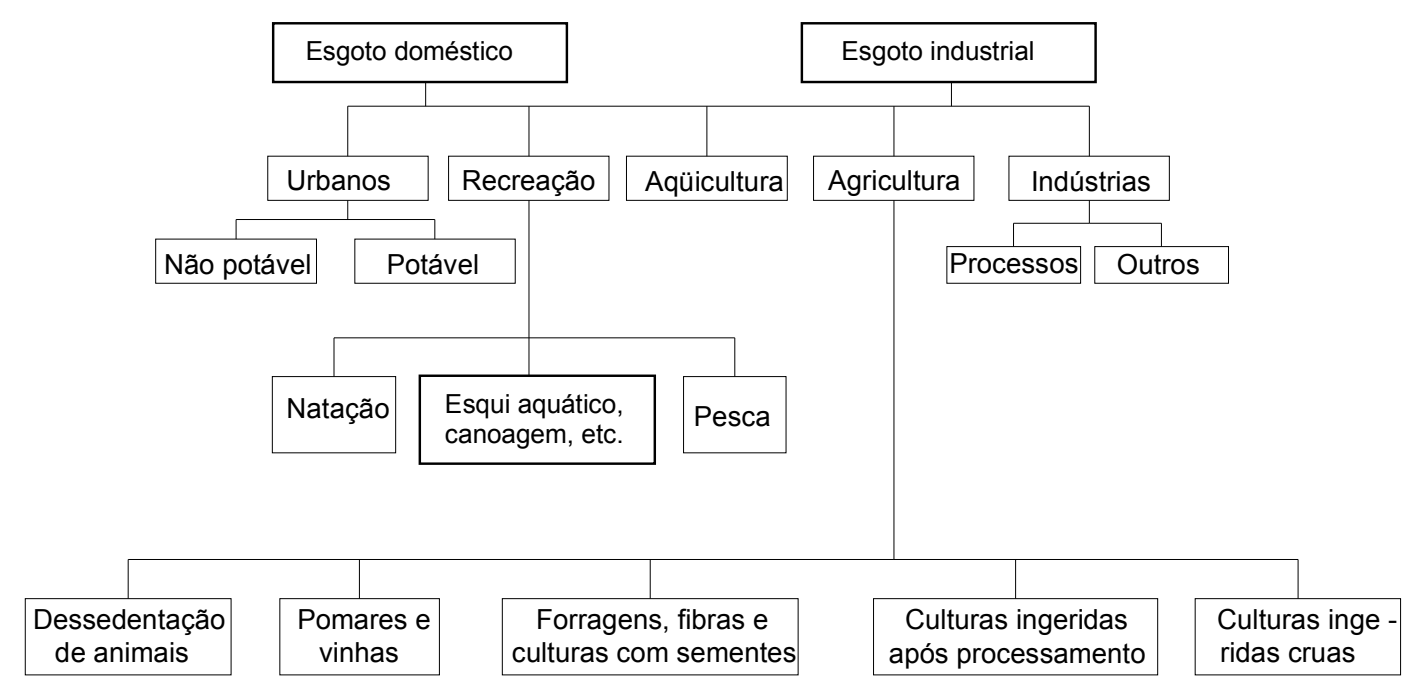

Figura 2 - Usos potenciais de esgotos tratados

Fonte: Hespanhol (1999)

As diretrizes para a água de reúso variam de acordo com o país ou organização que propõe os parâmetros. A World Health Organisation (WHO) apresenta as diretrizes de reúso da água apenas para agricultura e aqüicultura. A United States Environmental Protection Agency (USEPA), por sua vez, apresenta diretrizes para reúso de água em recarga de aqüíferos, irrigação de alimentos, água para fins paisagísticos, uso industrial e também emprego na construção civil (CROOK, 1994).

Em edifícios de escritórios, a água de reúso poderia ser empregada na irrigação de jardins, em sistemas decorativos (fontes, chafarizes), para proteção contra incêndio, lavação de veículos e calçadas, máquinas de lavar roupas e nas descargas das bacias sanitárias, além de outras possíveis máquinas e equipamentos que utilizem água em seus processos. 


\section{Aproveitamento de Água Pluvial}

A utilização de água pluvial também é uma alternativa que pode levar a um menor consumo de água potável, caso empregada para determinados fins que não necessitem de água de qualidade superior à da chuva. Além da economia de água potável, há a vantagem da retirada de carga do sistema de drenagem urbana, muitas vezes comprometido pela excessiva impermeabilização do solo. Ao coletar e utilizar a água da chuva, esta quantidade de água deixa de ser escoada no horário de pico, não sobrecarregando o sistema de drenagem pluvial.

Em algumas cidades brasileiras já existe a obrigatoriedade da construção de reservatórios para armazenamento de água pluvial em edificações novas para amenizar o referido problema. Em São Paulo, o sistema deve ser instalado quando a área impermeabilizada resulta em mais de $500 \mathrm{~m}^{2}$ de acordo com a Lei Municipal 13.276 de 04 de janeiro de 2002. A mesma lei municipal estabelece que, para o caso de reformas, o sistema deve ser instalado quando o acréscimo de área impermeabilizada for igual ou superior a $100 \mathrm{~m}^{2}$ (SÃO PAULO, 2002). O intuito da construção destes reservatórios é o alívio do sistema de drenagem urbana no horário de pico, já que o volume armazenado seria descartado após a chuva. Uma vez armazenada, descartá-la simplesmente, em alguns casos, poderia ser um contra-senso, já que esta água poderia ser utilizada para diversos fins benéficos. Alguns usos mais comuns da água pluvial em edifícios são a rega de jardins e a descarga em bacias sanitárias (TOMAZ, 2001).

No semi-árido brasileiro, a construção de reservatórios para armazenamento de água pluvial trouxe uma série de benefícios para a população, como a diminuição de doenças (MAY, 2004). A água pluvial armazenada é utilizada para o preparo de alimentos e para beber, sendo captada no período chuvoso e utilizada o ano todo. As comunidades recebem 
também um treinamento para que descartem as primeiras águas, que limpam o telhado e para que tratem a água com cloro (ARTICULAÇÃO NO SEMI-ÁRIDO BRASILEIRO, 2004).

Alguns pontos precisam ser verificados ao se pensar em aproveitamento de água pluvial. A qualidade é o primeiro. A caracterização da água coletada é necessária para que possa haver uma comparação com os parâmetros mínimos exigidos para os diferentes usos. Para a implantação do sistema, segundo May (2004), três fatores básicos devem ser verificados quando da análise de viabilidade: a precipitação, a área de coleta e a demanda.

Em edifícios, a referida autora afirma que o sistema de armazenamento pode estar enterrado ou apoiado no nível do chão, havendo a necessidade de recalque aos pontos de utilização (no caso das bacias sanitárias, por exemplo). Outra opção é projetar o reservatório de modo que fique apoiado na laje do edifício. Nesse caso, deve ser verificada a disponibilidade de espaço físico e a sobrecarga na estrutura do edifício.

\section{REFERÊNCIAS BIBLIOGRÁFICAS}

ARTICULAÇÃO NO SEMI-ÁRIDO BRASILEIRO. Programa de Formação e Mobilização Social para a Convivência com o Semi-Árido: Um Milhão de Cisternas Rurais. Disponível em <http://www.asabrasil.org.br>. Acesso em: 05 abr. 2004.

ASSOCIAÇÃO BRASILEIRA DE NORMAS TÉCNICAS - ABNT. NBR 13969: Tanques Sépticos - Unidades de Tratamento Complementar e Disposição Final dos Efluentes Líquidos - Projeto, Construção e Operação. Rio de Janeiro, 1997.

BLUM, J. R. C. Critérios e padrões de qualidade da água. In: MANCUSO, P. C. S. Reúso de água. São Paulo: Editora Manole, 2002, cap. 5, p. 125-174.

CROOK, J. et al. Water Reuse. Water Environment Research Foundation, Estados Unidos, 1994.

FINK, D. R.; SANTOS, H. F. A Legislação de Reúso de Água. In: SANTOS, H. F.; MANCUSO, P. C. S. (org). Reúso de Água. Editora Manole. São Paulo, 2002.

GONÇALVES, O. M. Uso Racional da Água nos Edifícios. Disponível em 〈http://pcc5100.pcc.usp.br/05_Agua/uso\%20racional\%20agua-25-03-2002.pdf〉. São Paulo, 2002. Acesso em 20 de outubro de 2005. 
GONÇAlveS, O. M. et al. Conservação e Reúso da Água em Edificações. Prol Editora Gráfica. São Paulo, 2005.

HESPANHOL, I. Água e Saneamento Básico: uma Visão Realista. In: REBOUÇAS A. C.; BRAGA, B.; TUNDISI, J. G. (org). Águas Doces no Brasil. Escrituras, São Paulo, 1999.

HESPANHOL, I. Potencial de Reúso de Água no Brasil: Agricultra, Indústria, Município e Recarga de Aqüíferos. In: SANTOS, H. F.; MANCUSO, P. C. S. (org). Reúso de Água. Editora Manole. São Paulo, 2002.

LAVRADOR FILHO, J. Contribuição para o Entendimento do Reúso Planejado da Água e algumas Considerações sobre as Possibilidades no Brasil. Dissertação (Mestrado) Universidade de São Paulo. São Paulo, 1987.

MAY, S. Estudo da Viabilidade do Aproveitamento de Água de Chuva para Consumo Não Potável em Edificações. Dissertação (Mestrado) - Engenharia de Construção Civil, Universidade de São Paulo. São Paulo, 2004.

OLIVEIRA, L. H. Metodologia para Implantação de Programa de Uso Racional da Água em Edifícios. São Paulo, 1999. Tese de Doutorado em Engenharia de Construção Civil da Escola Politécnica - Universidade de São Paulo, São Paulo, 1999.

OLIVEIRA, L. H.; GONÇALVES. O. M. Metodologia para Implantação de Programa de Uso Racional da Água em Edifícios. Boletim Técnico da Escola Politécnica da Universidade de São Paulo, São Paulo, 1999.

SÃO PAULO. Lei Municipal 13.276 de 04 de janeiro de 2002. Torna obrigatória a execução de reservatório para as águas coletadas por coberturas e pavimentos nos lotes, edificados ou não, que tenham área impermeabilizada superior a 500 $\mathrm{m}^{2}$. São Paulo, 2002.

SAUTCHÚK, C. A. Formulação de Diretrizes para Implantação de Programas de Conservação de Água em Edificações. Dissertação (Mestrado em Engenharia) - Escola Politécnica da Universidade de São Paulo, São Paulo, 2004a.

SAUTCHÚK, C. A. Código de Prática de Projeto e Execução de Sistemas Prediais de Água: Conservação de Água em Edifícios. DTA n ${ }^{\circ}$ F3 do Programa Nacional de Combate ao Desperdício de Água. Brasília, 2004b.

TOMAZ, P. Economia de Água para Empresas e Residências, Navegar Editora, São Paulo, 2001. 


\section{APÊNDICE B - ESTUDO PARA APLICAÇÃO DOS CRITÉRIOS DE AVALIAÇÃO DE SUSTENTABILIDADE AMBIENTAL DOS SISTEMAS PREDIAIS HIDRÁULICOS E SANITÁRIOS EM UM EDIFÍCIO DE ESCRITÓRIOS EM JOINVILLE - SANTA CATARINA}

O edifício de escritórios em estudo se situa em Joinville, município da região norte do Estado de Santa Catarina. O empreendimento conta com área total de $10.053,52 \mathrm{~m}^{2}$, distribuída em um pavimento térreo mais 10 pavimentos. O terreno contém área total de $2.342,58 \mathrm{~m}^{2}$. Tanto o piso térreo como o $10^{\circ}$ piso são compostos por 9 salas; os demais pisos são compostos por 12 escritórios individuais cada, totalizando 126 unidades. Todas as salas de escritório possuem acesso direto às áreas de circulação comum. $\mathrm{O}$ piso térreo e o segundo pavimento abrigam ainda boxes de garagem.

A proposta de aplicação dos critérios de avaliação de sustentabilidade ambiental dos sistemas prediais hidráulicos e sanitários no edifício de escritórios em estudo está dividida em categorias de desempenho. A presente proposta tem o objetivo de balizar as ações de projeto para os sistemas prediais hidráulicos e sanitários do edifício de escritórios em estudo. Desta maneira, esse estudo de caso pretende firmar especificações para o projeto e execução dos sistemas prediais hidráulicos e sanitários do edifício de escritórios localizado na cidade de Joinville-SC, de forma a adequá-lo aos critérios de avaliação de sustentabilidade ambiental os sistemas prediais hidráulicos e sanitários propostos.

\section{Confiabilidade, qualidade, manutenabilidade dos sistemas prediais hidráulicos e sanitários}

A) Disponibilização de guia informativo para o administrador do edifício, com dados sobre os sistemas prediais hidráulicos e sanitários: deverá ser disponibilizado um guia informativo contendo informações sobre a manutenção preventiva dos sistemas prediais de água fria, água 
quente, esgoto sanitário, águas pluviais, além de sistemas de aproveitamento de águas pluviais e de reúso da água. O guia também deve conter informações sobre conservação da água, recomendações sobre a utilização dos componentes dos sistemas prediais hidráulicos e sanitários, processos de limpeza e conservação dos componentes, periodicidade de inspeções e manutenções dos sistemas, técnicas, processos e equipamentos necessários para manutenção, além de informações sobre responsabilidades e garantias. Deve ser indicada também a importância da implantação de um sistema de gestão do uso da água, dando algumas diretrizes de implantação quando da operação do edifício. A NBR 14037 (ABNT, 1998) recomenda ainda que o manual inclua também o conjunto completo de projetos e discriminações técnicas atualizadas em relação ao que foi realmente construído.

B) Provisão de projetos "como construído" dos sistemas prediais hidráulicos: essa etapa deve ser cumprida após a execução do edifício de escritórios, devendo haver a entrega dos projetos as built, que representem fielmente o que foi executado.

C) Treinamento e conscientização dos usuários: essa etapa também deve ser cumprida após a ocupação do edifício, devendo haver ações contínuas de treinamento dos usuários e de conscientização quanto ao uso da água, à operação e manutenção dos sistemas prediais hidráulicos e sanitários.

D) Uso de diferentes cores para identificação dos sistemas prediais que transportam água não potável: os sistemas prediais que transportam água potável serão diferenciados dos sistemas que transportam água não-potável no projeto do edifício de escritórios em estudo seguindo as mesmas prescrições constantes na NBR 6493 (ABNT, 1980), que fixa os seguintes padrões para identificação de tubulações: 
- tubulação que transporta água potável: pintura verde e

- tubulação de combate a incêndio: pintura vermelha.

Para a tubulação componente do sistema de reúso da água no edifício em estudo, será utilizada a padronização citada por Santos (2002), sendo, portanto, empregada a pintura púrpura na tubulação. Para os demais sistemas hidráulicos e sanitários será utilizada a padronização proposta por Engwhere (s.d.):

- tubulação que transporta águas pluviais: pintura marrom e

- tubulação que transporta esgoto sanitário: pintura preta.

Além da pintura da tubulação, também deve haver no projeto a identificação do sistema de reservação e de distribuição da água de reúso e de águas pluviais, através do emprego de placas indicativas com a frase "Água não potável - não beba". Para o edifício em estudo também devem ser utilizadas torneiras de acesso restrito, operadas com sistemas de chaves destacáveis, para evitar o consumo de forma incorreta.

E) Manutenabilidade: previsão de dispositivos de fechamento dos sistemas prediais de suprimento de água de maneira setorizada e de acesso para manutenção dos sistemas prediais hidráulicos: o projeto deve prever a utilização de registros de fechamento no barrilete, nas colunas de distribuição e nos ramais de distribuição de água. Os sistemas prediais hidráulicos e sanitários devem ser inspecionáveis, o que facilita a manutenção. Além disso, para o edifício de escritórios em estudo, a localização dos reservatórios de água deve permitir as limpezas periódicas.

F) Controle da manutenção da temperatura da água no sistema predial de água quente: previsão de sistema de controle e gestão: no edifício de escritórios em estudo são previstos 
apenas cinco pontos de abastecimento de água quente, nos chuveiros localizados no pavimento térreo. Recomenda-se que o projeto seja realizado de acordo com a NBR 7198 (ABNT, 1993) que exige que os aquecedores sejam dotados de dispositivo automático de controle da temperatura máxima admissível da água. A mesma Norma Técnica fixa a temperatura máxima da água nos sistemas prediais de água quente em $70^{\circ} \mathrm{C}$.

G) Confiabilidade - continuidade de abastecimento: no edifício de escritórios em estudo é previsto um volume de reservação para o consumo de um dia, de modo a garantir o abastecimento, mesmo quando houver descontinuidade no fornecimento público. Propõe-se que o volume de reservação seja calculado considerando o número de usuários do edifício e o consumo diário de 30 litros/usuário, conforme prescrição do CSTB (2004).

H) Provisão de água com a qualidade requerida pelo usuário, com vazões, pressões e temperaturas adequadas ao uso e no horário em que o usuário necessita: para o projeto em questão deve haver a verificação de volumes e cotas dos reservatórios, verificação do atendimento das pressões dinâmicas mínimas de cada aparelho sanitário e a verificação dos diâmetros empregados. As ações para garantia de manutenção da qualidade sanitária da água são especificadas no presente estudo, na categoria "saúde e qualidade sanitária da água".

I) Projeto dos sistemas prediais hidráulicos e sanitários de modo a evitar a geração de ruídos, grandes vibrações e sobrepressão nos componentes dos sistemas: para isso, no projeto são propostas as seguintes ações na concepção dos projetos hidráulicos e sanitários:

- limitação da velocidade de escoamento da água nos sistemas prediais de suprimento de água à velocidade máxima de 3,0 m/s, proposta pela NBR 5626 (ABNT, 1998); 
- isolamento de tubulações, equipamentos e demais componentes sujeitos a esforços dinâmicos de modo que não sejam propagadas vibrações à estrutura de sustentação do edifício.

- limitação de vibrações nos sistemas elevatórios;

- especificação de componentes que não permitam fechamentos repentinos;

- limitação da sobrepressão no fechamento de válvulas de descarga a 0,2 MPa;

- concepção de modo a impedir deslocamento de bolsões de ar nas tubulações.

- concepção de modo a impedir distúrbios no fluxo de suprimento de água em tubulações, conexões e acessórios;

- concepção de modo a impedir distúrbios devido ao excesso de pressão no suprimento e

- especificação de aparelhos sanitários de modo a impedir distúrbios no escoamento quando do esvaziamento e devido ao esguichamento e espargimento de água quando do enchimento ou uso.

J) Projeto dos sistemas prediais hidráulicos e sanitários de modo a evitar a entrada de gases no interior do edifício: o impedimento de retorno dos gases do sistema predial de esgoto sanitário ao interior do edifício, no projeto do edifício de escritórios em estudo é garantido através do atendimento dos seguintes critérios:

- altura do fecho hídrico dos desconectores de todos os aparelhos sanitários, incorporados ou independentes, antes ou após a descarga, igual ou superior a $50 \mathrm{~mm}$;

- presença de subsistema de ventilação; 
- extremidades dos tubos ventiladores situados na cobertura do edifício guardam distâncias da cobertura, das janelas e portas, de acordo com o previsto na NBR 8160 (ABNT, 1999).

L) Segurança: aterramento da tubulação metálica, de equipamento, acessórios e de aquecedores elétricos: no projeto do edifício de escritórios em estudo, todas as tubulações, equipamentos e acessórios metálicos devem ser direta ou indiretamente aterrados. Além disso, quando houver a utilização de aparelhos aquecedores elétricos, os mesmos devem ser interligados ao sistema de aterramento, através de condutor de proteção, e devem apresentar corrente de fuga menor que $15 \mathrm{~mA}$, conforme proposto por ABNT (2004a).

\section{Saúde e qualidade sanitária da água}

A) Preservação da potabilidade da água: o projeto em questão conta com o abastecimento de água proveniente da concessionária pública municipal (Águas de Joinville), além de abastecimento proveniente de fontes alternativas, como aproveitamento de águas pluviais e reúso da água. Para assegurar a higiene dos sistemas prediais hidráulicos que transportam água potável, deve haver limpeza periódica dos reservatórios do sistema predial de água fria, além da exigência e verificação de laudos periódicos fornecidos pela concessionária sobre a qualidade da água.

Além disso, no projeto devem ser seguidas as recomendações propostas em ABNT (2004) quanto à separação física dos sistemas prediais hidráulicos de qualquer sistema que conduza água não potável ou fluido de qualidade insatisfatória, desconhecida ou questionável. Ou seja, as tubulações enterradas distam horizontalmente, no mínimo, 3,0 metros de qualquer 
fonte potencialmente poluidora, tais como tubulações enterradas de esgoto, fossas sépticas, sumidouros, valas de infiltração, etc. No projeto também não devem ocorrer ligações cruzadas do sistema de esgotos sanitários ou de sistema que transporte água proveniente de fontes alternativas com os sistemas prediais que transportam água potável.

O projeto deve prever tampas de fechamento dos reservatórios de modo a impedir a entrada de animais e corpos estranhos. A superfície superior externa possui declividade mínima de 1:3000 no sentido das bordas, não permitindo o acúmulo de água sobre o reservatório. A tampa deve ser elevada, no mínimo, $10 \mathrm{~cm}$ em relação ao piso acabado. $\mathrm{O}$ projeto dos reservatórios deve permitir inspeção e limpeza, possuindo ainda dispositivos de extravasão, limpeza e ventilação com as respectivas extremidades dotadas de crivo de tela com malha fina (ABNT, 2004).

B) Minimização dos riscos de contaminação por legionella Pneumophila: para minimizar tais riscos, o projeto dos sistemas prediais hidráulicos e sanitários do edifício em estudo deve levar em consideração os seguintes critérios:

- separação total dos sistemas que conduzem água fria e água quente;

- impedir a estagnação da água nos sistemas;

- impedir sedimentação e formação de biofilme.

No edifício em questão não haverá o emprego de torres de resfriamento. Para o caso de haver longos períodos sem a utilização dos sistemas prediais hidráulicos, no manual distribuído aos usuários do edifício deve ser proposta a utilização de métodos de desinfecção e posterior verificação de sua efetividade. 
C) Evitar respingamentos e a geração de aerossóis: para atender a esse critério, o projeto em questão deve trazer a especificação de peças de utilização que apresentem o fornecimento de água com adequada dispersão do jato e de louças sanitárias que estejam de acordo com as normas técnicas pertinentes. No presente projeto também se propõe que seja utilizado o limite máximo de pressão estática proposto pelo CSTB (2004), de $300 \mathrm{kPa}$, ficando de acordo também com a NBR 5626 (ABNT, 1998), que propõe o limite máximo de pressão estática de $400 \mathrm{kPa}$.

D) Evitar empoçamentos e refluxos: o projeto dos sistemas prediais hidráulicos do edifício de escritórios em estudo não deve permitir empoçamentos e refluxos de água. Devem ser atendidas as exigências da NBR 5626 (ABNT, 1998) quanto à separação atmosférica mínima dos sistemas, não permitindo a contaminação por refluxo. O projeto deve observar ainda que banheiras com torneiras afogadas, torneiras com possibilidade de conexão para mangueiras, bidês, lavadoras de louça e de roupas, duchas e outros equipamentos que possam vir a funcionar com a extremidade de saída de água em contato com a água servida devem ser dotados de dispositivo quebrador de vácuo, assim como caixas de descarga e reservatórios com alimentação afogada.

\section{Uso racional da água}

A) Utilização de equipamentos economizadores: no projeto dos sistemas prediais hidráulicos do edifício de escritórios em estudo serão utilizados os seguintes equipamentos economizadores de água:

- torneiras com funcionamento hidromecânico nos banheiros das unidades; 
- torneira com acionamento por válvula de pé na cozinha;

- arejadores nas torneiras de banheiros e cozinhas;

- torneiras de comando restrito na área comum do edifício;

- bacias sanitárias com caixa acoplada e volume de descarga por acionamento igual a 6 litros;

O emprego desses equipamentos economizadores visa à minimização do consumo de água, reduzindo a demanda de água potável e o volume de esgoto a ser tratado, sem prejuízo ao conforto dos usuários.

B) Medição e monitoramento: no edifício de escritórios em estudo se sugere a previsão de sistema de medição de consumo de água de maneira setorizada, de modo que cada unidade possua uma conta individual. Com isso, se espera que haja uma maior consciência quanto ao uso da água e que sejam estabelecidos parâmetros de controle para detecção de possíveis anomalias no consumo e correção de vazamentos.

C) Conscientização dos usuários: devem ser propostos no guia informativo a ser disponibilizado aos usuários, meios para realização de campanhas periódicas de conscientização. Tais campanhas podem incluir ações como a distribuição de folhetos explicativos, cartazes, publicações em veículo de comunicação interna do edifício, distribuição de manuais de operação e manutenção dos equipamentos e a realização de palestras de conscientização e de treinamento dos usuários, conforme proposto por Silva e Gonçalves (s.d). 
D) Paisagismo eficiente: projeto prevendo a utilização de espécies locais (redução da necessidade de irrigação): o edifício de escritórios em estudo possui um jardim no piso térreo com área de $35,55 \mathrm{~m}^{2}$. Não haverá sistema fixo de irrigação pois o projeto paisagístico deve prever a utilização de espécies de plantas adaptadas à região de Joinville. Deve haver, no entanto, uma torneira de acesso restrito pertencente ao sistema de aproveitamento de águas pluviais instalada no local, para eventual necessidade de irrigação.

E) Evitar o desperdício qualitativo: no edifício de escritórios em estudo todos os componentes dos sistemas prediais e os materiais especificados devem ser atestados pelos órgãos competentes, não interferindo no padrão de potabilidade da água. As peças de utilização não devem permitir a ocorrência de retrossifonagem e o trajeto da tubulação não deve incluir ligações cruzadas.

F) Localização otimizada de aquecedores e isolamento da tubulação de água quente: no empreendimento em estudo os pontos de consumo de água quente são localizados em uma mesma área do edifício. Propõe-se que o sistema de aquecimento de água esteja localizado próximo a estes pontos e que a tubulação utilizada no sistema predial de água quente seja isolada termicamente de maneira adequada.

\section{Carga na infra-estrutura local (drenagem pluvial)}

Deve haver, no projeto do edifício de escritórios em estudo, a previsão de sistema de detenção temporária de água pluvial para posterior aproveitamento. Devem ser empregados também pavimentos permeáveis no edifício, possibilitando uma taxa maior de infiltração no 
solo, conforme proposto por Silva (2003).

Quanto à recuperação e tratamento de água de escoamento superficial, para o edifício de escritórios em estudo, a área em que haverá este tipo de escoamento se localiza na parte térrea, sendo utilizada como área de tráfego de veículos e de estacionamento. Neste caso, é provável que haja algum tipo de contaminação proveniente dos veículos (graxas, óleos) e do tráfego, tanto de pessoas como de automóveis. Para verificar as possibilidades de tratamento desta água, se sugere que seja realizada uma avaliação da qualidade da água captada pelo sistema de drenagem do edifício. Através dessa avaliação poderá ser verificada a necessidade e o grau de tratamento exigido para descarte na rede pública ou até mesmo para posterior utilização dessa água.

\section{Carga na infra-estrutura local (tratamento de efluentes)}

A região em que se localiza o edifício de escritórios em estudo não é atendida pelo sistema público de coleta de esgotos sanitários que, em Joinville, contempla apenas $17 \%$ dos habitantes do município (informação pessoal) ${ }^{3}$. Segundo Knie (2003), os efluentes domésticos gerados na área não atendida pela rede pública de coleta de esgotos sanitários são despejados na rede de drenagem pluvial, contaminando córregos e rios do município. A legislação municipal exige tratamento prévio ao despejo de águas residuárias em corpos d'água (JOINVILLE, 1993). A prática usual (e o exigido pela fiscalização) no município, no caso de esgotos domésticos, é o emprego de fossa séptica e filtro anaeróbio (informação pessoal) ${ }^{4}$. A legislação estadual (SANTA CATARINA, 1981) faz algumas exigências não contempladas na resolução $n^{\circ} 357$ do Conselho Nacional do Meio Ambiente (BRASIL,

\footnotetext{
${ }^{3}$ ROCHA, C. Mensagem recebida por andreza@olimpiatur.com.br em 16 jun. 2006.

${ }^{4}$ ROCHA, C. Mensagem recebida por andreza@olimpiatur.com.br em 16 jun. 2006.
} 
2005), estabelecendo que os efluentes somente poderão ser descartados em corpos d'água (direta ou indiretamente), se obedecerem a condições estabelecidas, como $\mathrm{pH}$, temperatura, vazão, proporção de materiais sedimentáveis e de óleos e graxas. Já ABNT (1997) atesta a possibilidade de lançamento de esgoto sanitário, após tratamento adequado, em galerias de águas pluviais, se atender a alguns requisitos.

Para o edifício de escritórios em estudo, onde a geração de esgotos sanitários é de origem doméstica apenas, deve ser previsto um sistema de tratamento dos efluentes do edifício in loco que atenda a legislação citada. Para isso, recomenda-se o emprego de fossa séptica, filtro anaeróbio, seguidos de um sistema bastante utilizado na região, o tratamento por leitos cultivados (constructed wetland). Valentim (2003) cita a possibilidade de utilização do sistema em condomínios para tratamento de esgoto de origem doméstica, apresentando boa capacidade de redução de DBQ, Sólidos Suspensos Totais e Turbidez.

Iniciada a operação do edifício e conseqüentemente, o tratamento, a recomendação é que haja verificação periódica das características do efluente tratado para comparação com os parâmetros da legislação citada e da NBR 13969 (1997). Após essa verificação podem ser estudadas outras possibilidades de utilização desse efluente (reúso de água).

\section{Interferência do edifício em aqüíferos subterrâneos, áreas inundadas e cursos d'água}

A) Manutenção das características da água em aqüíferos subterrâneos, áreas inundadas e cursos d'água localizados no terreno: em pesquisa na Secretaria de Infra-estrutura Urbana (SEINFRA) de Joinville, constatou-se que o terreno em que se situa o edifício de escritórios em estudo não possui áreas inundadas ou cursos d'água em seu interior. A região de Joinville possui solo tipo síltico argiloso e apresenta dois tipos de aqüíferos, o aqüífero sedimentar e o 
aqüífero cristalino. $\mathrm{O}$ aqüífero sedimentar possibilita a exploração de água através de poços rasos, com profundidade máxima, na região, de 17 metros. $\mathrm{O}$ aqǘf́fero cristalino possibilita a extração de água através de poços profundos, com profundidade variando de 50 a 217 metros (KNIE, 2003). No caso do edifício de escritórios em estudo, as medidas de projeto dos sistemas prediais hidráulicos e sanitários para impedir a contaminação dos aqüíferos são a correta disposição e tratamento das águas servidas, tratamento e utilização de águas pluviais, além de cuidados de projeto que possibilitarão correta manutenção preventiva a fim de evitar qualquer tipo de contaminação.

B) Localização do terreno - distância mínima de corpos d'água: o terreno em que se localiza do edifício de escritórios em estudo dista 104,5 metros do rio Cachoeira, que corta o centro de Joinville. A largura do trecho do rio, medido in loco, é de aproximadamente 17 metros e, de acordo com a Lei Federal n 7.803 (BRASIL, 1989), a área de preservação permanente nas faixas de terra situadas ao longo de um rio com essas características é 50 de metros. Para o LEED (USGBC, 2002), a distância mínima de qualquer corpo d'água deve ser de, no mínimo, 30,48 metros. Desta maneira, o edifício de escritórios em estudo atende ao critério mencionado.

\section{Materiais componentes dos sistemas prediais hidráulicos e sanitários}

Para o edifício de escritórios em estudo, a especificação dos materiais componentes dos sistemas prediais hidráulicos e sanitários deve levar em consideração a adequação às normas técnicas da ABNT. Gonçalves et al (2005) relacionam a normalização técnica para aparelhos hidráulicos e materiais, que deve ser seguida quando da especificação dos materiais 
componentes dos sistemas prediais hidráulicos e sanitários do edifício de escritórios em questão. As seguintes normas técnicas são algumas das citadas pelos referidos autores:

- NBR 11535 (ABNT, 1991): misturadores para pia de cozinha tipo mesa especificação;

- NBR 11815 (ABNT, 1991): misturadores para pia de cozinha tipo parede especificação;

- NBR 11852 (ABNT, 1992): caixa de descarga - especificação;

- NBR 12483 (ABNT, 1992): chuveiro elétrico - padronização;

- NBR 12904 (ABNT, 1993): válvula de descarga - especificação;

- NBR 5649 (ABNT, 1994): reservatório de fibrocimento para água potável especificação;

- NBR 13713 (ABNT, 1996): aparelhos hidráulicos acionados manualmente e com ciclo de fechamento automático;

- NBR 14011 (ABNT, 1997): aquecedores instantâneos de água e torneiras elétricas - requisitos;

- NBR 14162 (ABNT, 1998): aparelhos sanitários - sifão - requisitos e métodos de ensaio;

- NBR 14534 (ABNT, 2000): torneira de bóia para reservatórios prediais de água potável - requisitos e métodos de ensaio;

- NBR 14390 (ABNT, 2001): misturador para lavatório - requisitos e métodos de ensaio;

- NBR 10281 (ABNT, 2003): torneira de pressão - requisitos e métodos de ensaio;

- NBR 12483 (ABNT, 2003): chuveiro elétrico - padronização;

- NBR 15097 (ABNT, 2004): aparelho sanitário de material cerâmico - requisitos e métodos de ensaio; 
- NBR 15099 (ABNT, 2004) aparelho sanitário de material cerâmico - dimensões padronizadas e

- NBR 15206 (ABNT, 2005): instalações hidráulicas prediais - chuveiros ou duchas - requisitos e métodos.

\section{Reúso da água}

No edifício de escritórios em estudos propõe-se a existência de um sistema de reúso da água proveniente dos lavatórios e chuveiros para utilização nas bacias sanitárias. Para isso devem ser previstas avaliações periódicas de qualidade da água e comparação com os parâmetros exigidos pela NBR 13969 (ABNT, 1997).

Para identificação do sistema, há a previsão de pintura da tubulação com a cor púrpura, e identificação do sistema de reservação e de distribuição da água de reúso através do emprego de placas indicativas com a frase “Água não potável - não beba”. Devem ser também utilizadas torneiras operadas com sistemas de chaves destacáveis para evitar o consumo de forma incorreta. Tais torneiras, no caso do sistema de reúso de água devem ser implantadas para que haja coleta de água para verificações periódicas de qualidade.

\section{Aproveitamento de águas pluviais}

No edifício de escritórios em estudo propõe-se a existência de um sistema de aproveitamento de águas pluviais. A água da chuva será captada na cobertura do edifício e será armazenada em reservatório específico. Essa água deve sofrer cloração e a qualidade da água armazenada 
deve ser periodicamente verificada. A água pluvial será utilizada na irrigação do jardim em períodos em que haja necessidade e para lavagem de calçadas. As torneiras que fazem parte do sistema são torneiras de acesso restrito, além de serem identificadas com placas que possuem a frase “Água não potável - não beba". Além disso, no projeto há a previsão de pintura da tubulação componente do sistema com a cor marrom e identificação do sistema de reservação e de distribuição da água de pluvial.

\section{CONSIDERAÇÕES FINAIS}

O presente estudo foi desenvolvido com o auxílio da lista de verificação de ações de sustentabilidade ambiental de sistemas prediais hidráulicos e sanitários. O objetivo é trazer aspectos relacionados à sustentabilidade ambiental no ambiente construído ao projeto técnico dos sistemas mencionados em um edifício de escritórios na cidade de Joinville-SC. A elaboração do projeto dos sistemas prediais hidráulicos e sanitários e dos manuais informativos aos usuários do edifício em estudo deve ser realizada com a utilização dos conceitos de construção ambientalmente sustentável. O presente estudo pretende dar algumas diretrizes para que isso ocorra. Desta forma, pretende-se incentivar práticas de conservação da água no ambiente construído e a aplicação dos conceitos de sustentabilidade ambiental no projeto e execução de sistemas prediais hidráulicos e sanitários.

\section{REFERÊNCIAS BIBLIOGRÁFICAS}

ASSOCIAÇÃO BRASILEIRA DE NORMAS TÉCNICAS - ABNT. NBR 6493: Emprego de Cores Fundamentais para Tubulações Industriais. Rio de Janeiro, 1980. 
ASSOCIAÇÃO BRASILEIRA DE NORMAS TÉCNICAS - ABNT. NBR 8160: Sistemas Prediais de Esgoto Sanitário - Projeto e Execução. Rio de Janeiro, 1999.

ASSOCIAÇÃO BRASILEIRA DE NORMAS TÉCNICAS - ABNT. NBR 13969: Tanques Sépticos - Unidades de Tratamento Complementar e Disposição Final dos Efluentes Líquidos - Projeto, Construção e Operação. Rio de Janeiro, 1997.

ASSOCIAÇÃO BRASILEIRA DE NORMAS TÉCNICAS - ABNT. NBR 14037: Manual de Operação, Uso e Manutenção das edificações: Conteúdo e Recomendações para Elaboração e Apresentação. Rio de Janeiro, 1998.

ASSOCIAÇÃO BRASILEIRA DE NORMAS TÉCNICAS - ABNT. NBR 5626: Instalações Prediais de Água Fria. Rio de Janeiro, 1998.

ASSOCIAÇÃO BRASILEIRA DE NORMAS TÉCNICAS - ABNT. NBR 7198: Projeto e execução de instalações prediais de água quente. Rio de Janeiro, 1993.

ASSOCIACAO BRASILEIRA DE NORMAS TÉCNICAS - ABNT/CB-02. Desempenho de Edifícios Habitacionais de até cinco Pavimentos - Parte 6: Sistemas Hidrossanitários. Projeto 02:136.01.008, Rio de Janeiro, 2004.

BRASIL. Lei $n^{\circ} 7.803$ de 15 de julho de 1989. Altera a redação da Lei $n^{0} 4.771$, de 15 de setembro de 1965, e revoga as Leis $n^{0} 6.535$, de 15 de julho de 1978 e 7.511 , de 7 de julho de 1986. Diário Oficial da União. Brasília, DF, 1989.

BRASIL. Conselho Nacional do Meio Ambiente. Resolução no 357 de 17 de março de 2005. Diário Oficial da União. Brasília, DF, 2005.

CENTRE SCIENTIFIQUE ET TECNIQUE DU BÂTIMENT - CSTB Référentiel de Certification Bâtiment Tertiaires: Démarche HQE Bureau et Enseinement. Paris, 2004.

ENGWHERE Orçamentos Ltda. Tabelas Técnicas Diversas. Disponível em: $<$ http://www.engwhere.com.br/engenharia/tabelas_eletrodutos_esgoto_incendio.htm $>$. Acesso em: 22 maio 2006.

GONÇAlveS, O. M. et al. Conservação e Reúso da Água em Edificações. Prol Editora Gráfica. São Paulo, 2005.

JOINVILLE. Lei complementar $n^{\text {o }}$ 07, de 29 de dezembro de 1993. Estabelece normas de proteção e conservação da saúde no Município, estabelece penalidades e dá outras providências. Prefeitura Municipal de Joinville, 29 dez. 1993.

KNIE. J. L. W. (Coord.) Atlas Ambiental da Região de Joinville: Complexo Hídrico da Baía da Babitonga. 2. ed. Florianópolis: FATMA GTZ, 2003.

SANTA CATARINA. Decreto Estadual nº 14.250, de 05 de junho de 1981. Diário Oficial do Estado, 09 jun. 1981. 
SANTOS, G. J. Água de Reúso para Lavagem de Ruas e Rega de Parques. In: SANTOS, H. F.; MANCUSO, P. C. S. (org). Reúso de Água. Editora Manole. São Paulo, 2002c, p. 501511.

SILVA, V. G. Avaliação da Sustentabilidade de Edifícios de Escritórios Brasileiros: Diretrizes e Base Metodológica. 2003. Tese (Doutorado em Engenharia) - Escola Politécnica da Universidade de São Paulo, São Paulo.

UNITED STATES GREEN BUILDING COUNCIL - USGBC. LEED: Green Building Rating System for New Construction and Major Renovations version 2.1. San Francisco, 2002.

VALENTIM, N. A. C. Desempenho de Leitos Cultivados ("Constructed Wetland") para Tratamento de Esgoto: Contribuições para Concepção e Operação. 2003. Tese (Doutorado em Engenharia Agrícola) - Universidade Estadual de Campinas, Campinas. 